\title{
Ecología y conservación del Cernícalo Primilla durante el periodo premigratorio
}




\title{
Ecología y conservación del Cernícalo Primilla durante el periodo premigratorio
}

\author{
Ángel de Frutos Tena \\ Área de Zoología \\ Departamento de Biodiversidad y Gestión Ambiental \\ Universidad de León \\ España
}

Memoria presentada para optar al grado de Doctor en Biología

Codirigida por:

Dr. Francisco José Purroy Iraizoz, Universidad de León, España Dr. Pedro Pérez Olea, IE Universidad, Segovia, España 
A mi familia

A $M^{\mathrm{a}}$ José y Rubén 


\section{Índice}

Introducción

Capítulo 1

Dormideros comunales premigratorios de Cernícalo

Primilla durante el verano boreal

\section{Capítulo 2}

2.1. Análisis y modelado de la distribución espacial de la abundancia del Cernícalo Primilla durante el verano: el papel de la autocorrelación espacial

2.2. Importancia de las áreas premigratoria en la conservación del Cernícalo Primilla: uso del espacio y selección de hábitat durante el periodo premigratorio

2.3. El papel del barbecho en el uso del hábitat por el Cernícalo Primilla durante el periodo premigratorio: implicaciones en la conservación de la abolición del barbecho obligatorio

2.4. Selección de hábitat de caza por el Cernícalo

Primilla Falco naumanni durante el periodo premigratorio

Conclusiones

\section{Anexo}

Implicaciones en la conservación y gestión ambiental del uso del módulo estadístico de partición jerárquica 
Introducción

\section{Introducción}

El presente trabajo de tesis doctoral se centra en el periodo premigratorio del Cernícalo Primilla (Falco naumanni Fleischer, 1818), un pequeño halcón amenazado y migrador trans-sahariano (Cramp \& Simmons 1980). El periodo premigratorio, o post-reproductor, es una parte del ciclo vital muy poco estudiada en aves migradoras (Rappole \& Ballard 1987; Baker 1993; Rivera et al. 1998). Este periodo abarca desde la independencia de los pollos hasta la migración, una fase que en algunas especies puede durar varios meses (Rappole \& Ballard 1987; Baker 1993; Rivera et al. 1998).

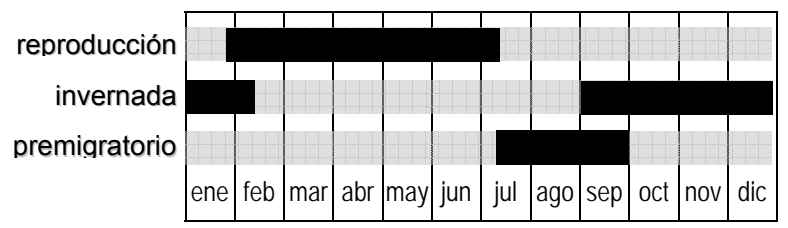

Figura 1. Ciclo anual aproximado del Cernícalo Primilla.

El escaso conocimiento sobre el periodo premigratorio en aves se debe principalmente a las dificultades de observación de individuos, bien porque las aves se vuelven muy discretas en sus áreas de cría (hasta dos meses y medio en el caso del Cernícalo Primilla, Olea et al. 2004, Fig.1) o bien porque abandonan estas áreas para permanecer en otras zonas antes de la migración (por ejemplo, paran de cantar; Rappole \& Ballard 1987).

Por consiguiente, la importancia que tiene el periodo premigratorio desde el punto de vista ecológico y de conservación es aún poco conocida en aves migradoras. Sin embargo, durante este periodo algunas especies realizan la muda (áreas premigratorias, Rappole \& Ballard 1987; Rivera et al. 1999; Olea et al. 2004) y además tienen que acumular reservas grasas (al menos parcialmente, ver Rivera et al. 1998) para llevar a cabo la migración. Puesto que la demanda energética para la muda y la migración es alta, la disponibilidad de suficientes recursos tróficos durante el periodo premigratorio debería ser importante para la supervivencia. La búsqueda de lugares con abundantes recursos tróficos antes de la migración probablemente es probablemente una de las razones que explican los desplazamientos observados por algunas 
especies hacia otras áreas diferentes de las de cría antes de migrar hacia sus áreas de invernada (Rivera et al. 1999). Estos movimientos, conocidos como migración estival, ocurren preferentemente hacia el norte de las áreas de cría [por ejemplo la Avutarda (Otis tarda), el Aguilucho Cenizo (Circus pygargus), el Sisón (Tetrax tetrax) y el Cernícalo Primilla en España (Olea 2001b; Morales et al. 2006; Limiñana et al. 2008)]. En el caso del Cernícalo primilla, este desplazamiento se produce en sentido opuesto a la verdadera migración (hacia África en sentido sur). Además, se ha observado que los jóvenes pueden dispersarse durante el verano hasta 600 kilómetros desde el área natal (Olea 2001b). La inexperiencia de los jóvenes en la búsqueda de comida y frente a los depredadores o actividades humanas hacen que el periodo premigratorio pueda ser particularmente crítico para la supervivencia de estos individuos (Anders et al. 1998). Por tanto, la supervivencia juvenil y la dispersión durante este periodo pueden tener importantes efectos en la dinámica poblacional (Hiraldo et al. 1996; Sergio et al. 2004; Penteriani et al. 2005). Sin embargo, los factores que limitan y regulan las poblaciones son escasamente conocidos en estas áreas de estancia premigratoria. Estas áreas podrían desempeñar por tanto un importante papel ecológico y de conservación de las aves migratorias. Sin embargo, las estrategias de conservación de las aves migratorias generalmente consideran únicamente los periodos de cría y de invernada (por ejemplo Rivera et al. 1998; Mabey \& Watts 2000), ignorando los periodos en los cuales los individuos pueden desplazarse o dispersarse a otras áreas [por ejemplo, zonas de parada migratoria (Petit 2000) y áreas premigratorias (véase Olea 2001b; Olea et al. 2004)]. Así por ejemplo, el Plan de Acción Internacional del Cernícalo Primilla (Biber 1996) no considera el periodo premigratorio y por ello, la conservación del Cernícalo Primilla puede fracasar si se aplican medidas de conservación de sus poblaciones sólo durante el periodo de cría dejándolas desprotegidas inmediatamente después (durante el periodo premigratorio; Olea 2001a; Tella 2004). Resulta imprescindible por tanto la puesta en marcha de programas de investigación, gestión y conservación de la especie durante el periodo premigratorio. Pero para ello hay que conocer los requerimientos básicos de la especie y sus necesidades de conservación durante este periodo. Esta tesis presenta resultados básicos de ecología y conservación del Cernícalo Primilla durante el periodo post-reproductor en una de las principales áreas premigratorias conocidas en Europa. 
Introducción

\section{Especie de estudio}

El Cernícalo Primilla es un pequeño halcón (90-200 gramos de peso y $30 \mathrm{~cm}$ de envergadura) que presenta un marcado dimorfismo sexual (Cramp \& Simmons 1980; González \& Merino 1990, Fig. 2). Puede ser fácilmente confundido con el Cernícalo Vulgar, particularmente en el caso de las hembras y los pollos. Varios caracteres morfológicos y etológicos permiten distinguir ambas especies, pero en ocasiones resulta difícil diferenciarlas con total fiabilidad (Negro 1991; Hiraldo et al. 1995).

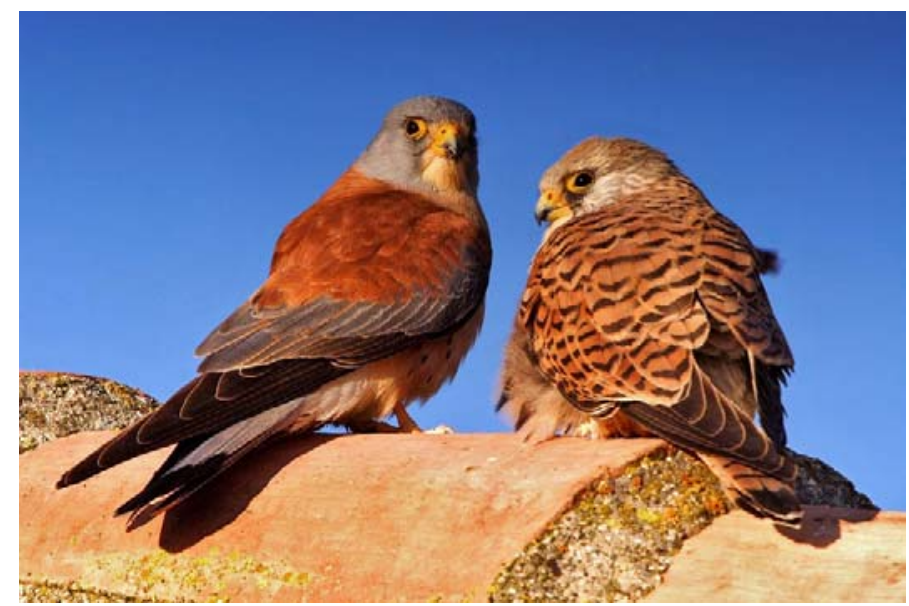

Figura 2. Macho (izquierda) y hembra (derecha) de Cernícalo Primilla. Autor: Jonathan Díaz Marbá

La población reproductora de Cernícalo Primilla se distribuye por la región Paleártica, desde el sur de Europa (cuenca mediterránea) hasta Mongolia y China alcanzando el Norte de África y Turquía (Fig. 3). Sus principales cuarteles de invernada se encuentran en el centro y sur de África (Tucker \& Heath 1994, Fig. 3), pero algunos individuos invernan en algunos puntos de la Península Ibérica (Valle de Guadalquivir, Los Monegros) (Negro \& Hiraldo 1993; Tella \& Forero 2000), en Italia y en el Norte de África (Sánchez 1997). 


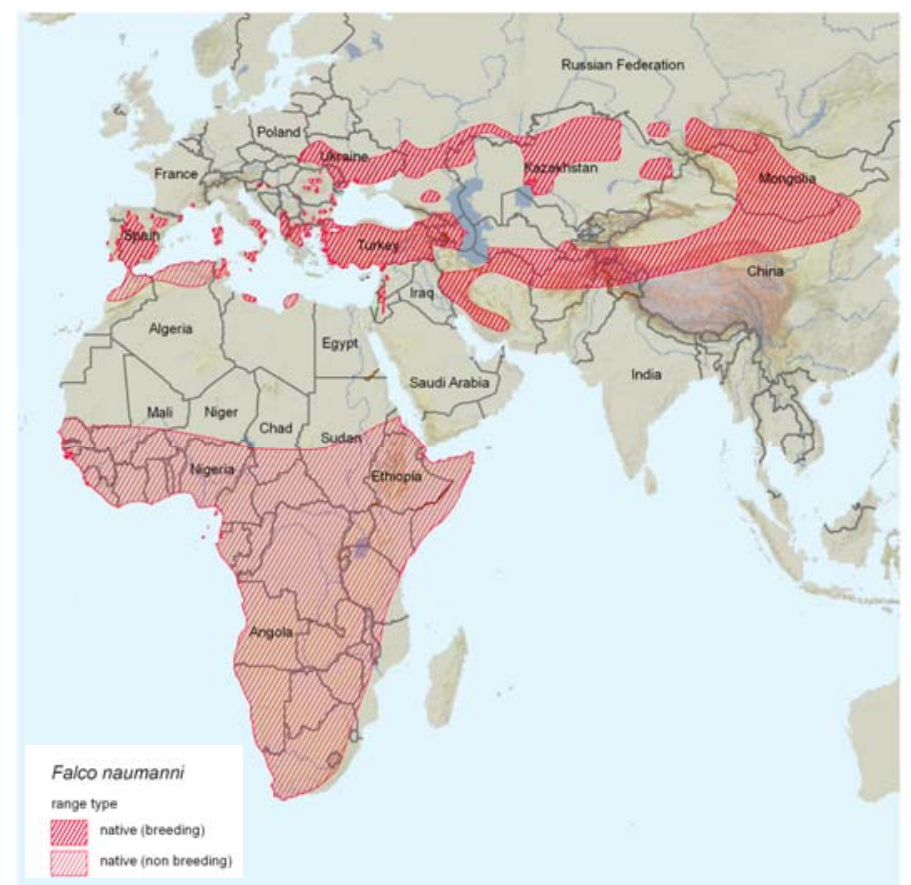

Figura 3. Distribución mundial del Cernícalo Primilla, detallando sus áreas de cría ("breeding") y sus cuarteles de invernada ("non breeding"). Modificado de BirdLife International 2009(González \& Merino 1990).

Los cernícalos primillas regresan a sus áreas de cría desde sus cuarteles de invernada hacia el mes de febrero. Es una especie colonial que nidifica fundamentalmente en edificios viejos o abandonados, tanto localizados en pueblos o ciudades como aislados en el campo. Presenta una alta filopatría (el $57 \%$ de los juveniles tienden a retornar a sus colonias natales) y una alta fidelidad a la colonia de cría (el $72 \%$ de los adultos) (Serrano et al. 2001; Serrano \& Tella 2003; Serrano et al. 2003). Sin embargo, casi el $75 \%$ de los individuos cambian de nido y de pareja anualmente. Es una especie monógama, pero en ocasiones se han descrito casos de poliginia (tríos; Hiraldo et al. 1991). El periodo de celo (cebas de cortejo y cópulas) comienza a principios de abril. Las puestas, habitualmente compuestas por 4 ó 5 huevos, tienen lugar desde la segunda quincena de abril hasta la primera de junio. Los pollos eclosionan tras 28 días de incubación, permanecen en el nido alrededor de un mes y abandonan las colonias pocos días después de volar (5 días 
de media; Bustamante \& Negro 1994). Realizan sus primeros vuelos entre finales de junio y la primera quincena de julio, y pueden llevar a cabo dispersiones juveniles premigratorias (García 2000; Olea 2001b), desplazándose desde sus colonias natales una media de $210 \mathrm{~km}$ preferentemente hacia el norte antes de iniciar la migración al sur (Olea 2001b). Estas dispersiones parecen ser debidas a la abundancia de recursos tróficos en las áreas premigratorias, donde la especie puede congregarse en grandes dormideros comunales estivales (hasta más de 1000 individuos; Olea 2001a; Ursúa \& Tella 2001). Las poblaciones migradoras realizan su viaje trans-sahariano entre septiembre y octubre (Bernis 1980).

Se alimenta básicamente de insectos, particularmente ortópteros, en especial saltamontes y grillos, y con menor frecuencia, sobre todo en la época reproductora, de ratones, topillos y lagartijas que habitualmente caza desde el aire (Franco \& Andrada 1977; Heredia et al. 1996, Fig. 4).

El Cernícalo Primilla habita en áreas abiertas. Se ha adaptado exitosamente a vivir en áreas agrícolas con cultivos extensivos, sobre todo de secano, y con escasa presencia de árboles.

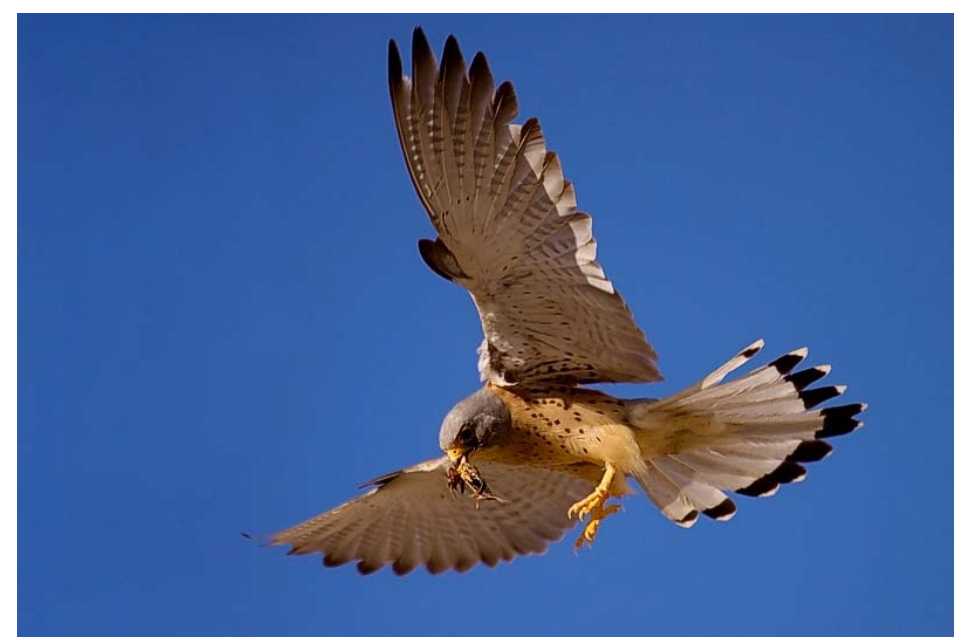

Figura 4. Macho de Cernícalo Primilla portando un ortóptero. Foto: Javier Milla López

Actualmente está catalogado como especie amenazada tanto a nivel mundial como a nivel nacional ("Vulnerable"; Atienza \& Tella 2004; BirdLife International 2009b). La especie ha sufrido un gran declive 
poblacional durante las últimas décadas. Por ejemplo en España se estima que la población actual (12.000 parejas reproductoras) representa sólo un $5 \%$ de la estimada en los años 70 (unas 100.000 parejas; Atienza \& Tella 2004). España alberga actualmente a más del $50 \%$ de la población europea (21.000-33.000 parejas; Atienza \& Tella 2004). La población de Primilla de la provincia de León, donde se encuentra nuestro área de estudio (ver siguiente apartado), no supera las 100 parejas reproductoras y sufrió una retracción en su área de distribución (Olea \& García 1997; Olea 2001a).

Se ha sugerido que son varias las causas responsables de la fuerte regresión poblacional, destacando la pérdida de lugares de nidificación (huecos y edificios) y de hábitat de alimentación, la reducción de la disponibilidad de presas debido al uso de insecticidas, la competición interespecífica por los lugares de nidificación (Donázar et al. 1993; Forero et al. 1996; Tella 2004). Algunos autores sugieren que la mayor amenaza es la pérdida de hábitat de alimentación, debido principalmente a la intensificación agrícola en las últimas décadas (Donázar et al. 1993; Tella et al. 1998). Estas prácticas agrícolas modernas, promovidas por la PAC (Política Agraria Comunitaria), han supuesto cambios en la rotación de cultivos, transformación de cultivos de secano a regadío, una mayor homogeneidad paisajística, un mayor uso de biocidas y la eliminación de hábitat semi-naturales (linderos y barbechos) (Petit \& Firbank 2006).

Existe mucha información científica sobre el Cernícalo Primilla durante el periodo de cría, por ejemplo sobre la biología reproductiva (Hiraldo et al. 1991; Negro et al. 1992; Negro \& Hiraldo 1993; Tella et al. 1997; Aparicio \& Bonal 2002; Rodríguez \& Bustamante 2003), ecología trófica y comportamiento de caza (Franco \& Andrada 1977; Donázar et al. 1993; Negro et al. 1993; Vlachos et al. 2003; Franco \& Sutherland 2004; García et al. 2006; Rodríguez et al. 2006; Bonal \& Aparicio 2008), dispersión natal y de cría (Negro et al. 1997; Serrano et al. 2001; Serrano et al. 2003; Serrano et al. 2004; Ortego et al. 2008), conservación y manejo (Hiraldo et al. 1994; Hiraldo et al. 1996; Bustamante 1997; LivenSchulman et al. 2004). En menor medida existen también estudios sobre el periodo invernal, como la selección de hábitat (Tella \& Forero 2000), distribución y abundancia de primillas (Negro et al. 1991), dieta (Anderson et al. 1999; Kopij 2002) y uso de dormideros comunales invernales (Siegfried \& Skead 1971). Sin embargo se conoce muy poco sobre el 
periodo premigratorio. Se ha demostrado que la especie realiza dispersiones premigratorias hacia el norte (García 2000; Olea 2001b) y que puede congregarse en grandes dormideros comunales en áreas donde la población reproductora es baja o está ausente (Olea 2001a; Ursúa \& Tella 2001). Se desconoce aún los efectos que pueden tener en la dinámica poblacional estas dispersiones premigratorias, la estancia en áreas lejanas y el uso de dormideros, así como los requerimientos ecológicos y de conservación de la especie para este periodo. Esta falta de información y el grado de amenaza justifican el interés del Cernícalo Primilla como especie de estudio de la presente tesis. Además se la considera como especie "paraguas" de la biodiversidad asociada a los agrosistemas extensivos de secano (Biber 1996; Rodríguez \& Wiegand 2009).

\section{Área de estudio}

El área de estudio está situada al Sureste de la provincia de León a 800 m.s.n.m., entre las localidades de Santas Martas, Matanzas y Sahagún (centrada geográficamente a $5^{\circ} 15^{\prime} \mathrm{W}$ y $42^{\circ} 21^{\prime} \mathrm{N}$, Fig. 5). Está comprendida entre las comarcas de Los Oteros y Tierra de Campos. La temperatura media es de $11,7^{\circ} \mathrm{C}$ y la precipitación media anual es de $486 \mathrm{~mm}$. En verano, la temperatura media es de $19^{\circ} \mathrm{C}$ y alrededor de $20 \mathrm{~mm}$ de precipitación media mensual (Olea 2001b). Bioclimáticamente pertenece al piso supramediterráneo de la región biogeográfica Mediterránea (Penas et al. 1995).

El área abarca una extensión aproximada de $1200 \mathrm{~km}^{2}$. Las formaciones geológicas dominantes son fundamentalmente de arcillas arenosas y rañas (formadas por cantos de cuarcita) y existen numerosas lagunas endorreicas pequeñas de acentuada temporalidad. Es una superficie poco accidentada con vegetación de escaso porte (Fig. 6). Existen algunos valles pequeños y poco profundos en dirección norte-sur donde crecen pastizales y choperas.

El principal uso de suelo del área de estudio es la agricultura extensiva de secano (aprox. el $81.7 \%$ de la superficie del área; Fig. 7), en régimen de año y vez. Predominan el cereal de secano (aprox. el 50.4\% de la superficie agrícola) y los barbechos recién arados (30.8\%), y en menor medida existen otros cultivos: leguminosas (altramuz, guisantes y 
alfalfa de secano; 8.4\%; Fig. 8), barbecho no arado (5.3\%), regadíos (maíz, remolacha, huertos y alfalfa de regadío; $2.8 \%$ ), viñedos (1.5\%) y girasoles $(0.8 \%)$.

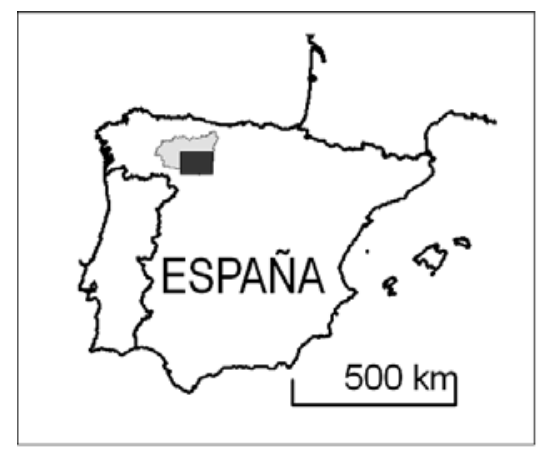

Figura 5. Localización del área de estudio (rectángulo negro) en el sureste de la provincia de León.

El cereal se siembra en octubre; se cosecha en julio y las parcelas quedan como rastrojos hasta su posterior arado, principalmente en febrero-marzo del siguiente año (Fig. 9). Esta parcela arada puede quedar bien como: i) barbecho blanco, es decir, no lo siembran tras el arado; posteriormente gradean la parcela en mayo-junio quedando desprovista de vegetación y siembran cereal en octubre; o ii) barbecho semillado, es decir, siembran tras arar el rastrojo, normalmente leguminosas o cereal tardío; en julio la recogen, y en octubre aran y siembran la parcela.

Hemos definido como linderos aquellas zonas formadas fundamentalmente de plantas herbáceas, arbustos de escaso porte y suelo desprovisto de vegetación que se encuentran en los bordes de caminos (cunetas; Fig. 10). No existen prácticamente linderos entre parcelas de cultivo en el área estudiada. La anchura media de los linderos encontrados durante el verano de 2001 fue de $3,3 \mathrm{~m}(S D=1,3$; $n=94$ ). Los linderos son de propiedad privada de los agricultores y están frecuentemente pastados por el ganado doméstico, particularmente ovino, y en ocasiones son tratados con herbicidas (Pouillard 2007). 
Introducción

(a)



(b)

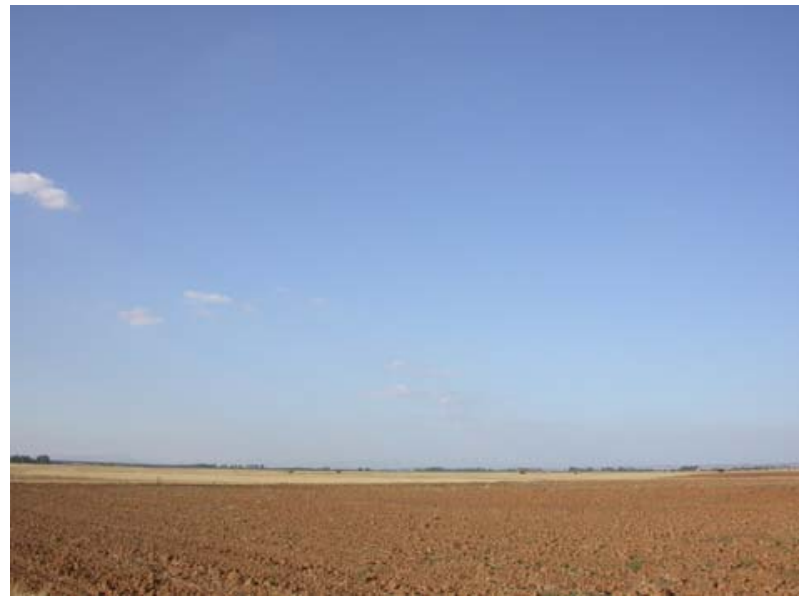

Figura 6. Paisaje del área de estudio durante el verano. Se observan parcelas de rastrojo de cereal de secano, de alfalfa (a) y de barbechos arados (b). 
Introducción

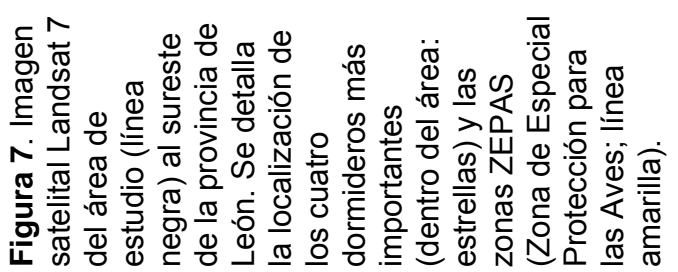

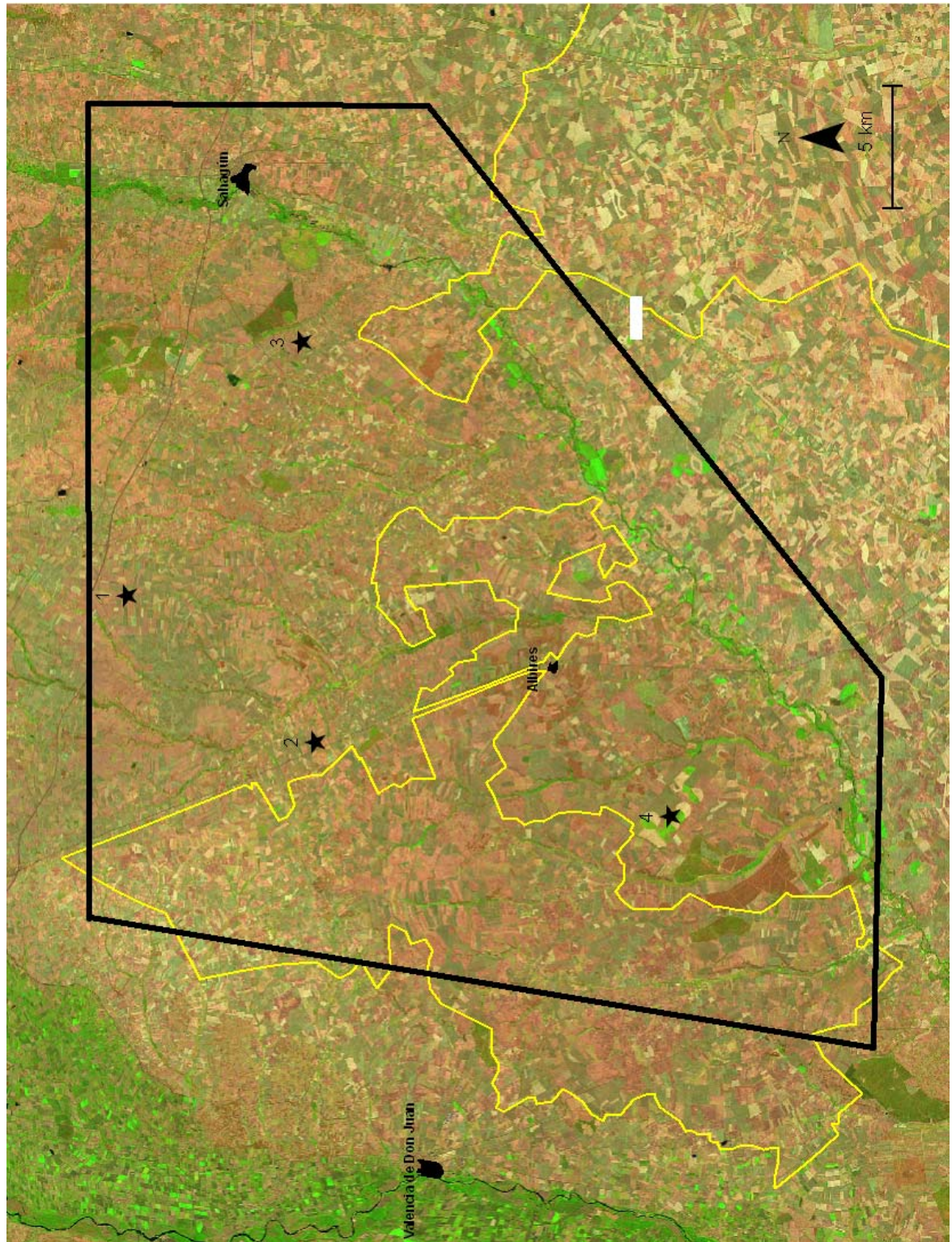






Figura 8. Cultivo de alfalfa de secano, recién segada, usado por un grupo de avutardas en el área de estudio, sureste de León.

a)
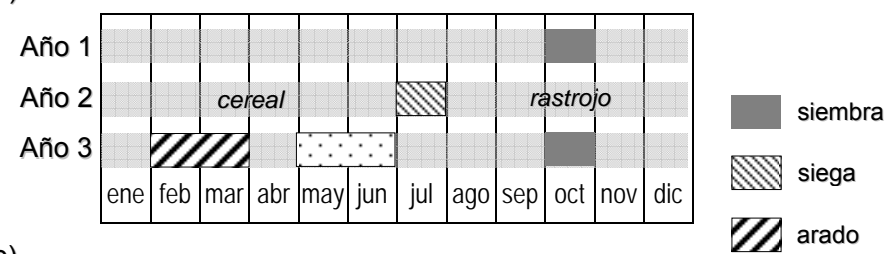

b)

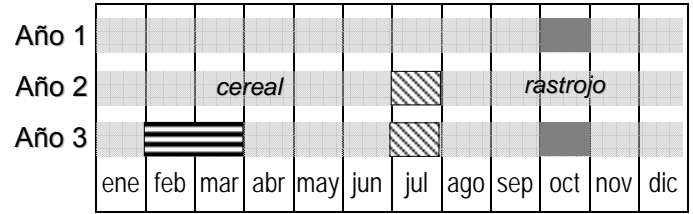

$\because \cdot$ gradeado arado y siembra de
cereal o leguminosas

Figura 9. Calendario del cultivo de secano en el Sureste de León. Se indican los meses en los que se realizan las actividades agrícolas para cada año según la práctica llevada a cabo: barbecho blanco (a) o barbecho semillado (b.) Cada barra representa un año natural (año $1,2$ y 3$)$. 
Parte del área de estudio está declarada como Zona Especial de Protección para las Aves (ZEPAs de Oteros-Campos, de Oteros-Cea y de La Nava-Campos Norte; Fig. 7). Otra parte ha sido recientemente declarada como zona regable para la implantación de cultivos de regadío (como maíz y remolacha) a través del Plan Nacional de Regadíos (MAPA 2002) promovido por la PAC (Política Agraria Comunitaria; Fig 9). Este hecho implicará importantes cambios en las prácticas agrícolas actuales basadas en un agrosistema de secano con pastoreo ovino en los rastrojos, una baja mecanización y un bajo uso de fertilizantes y biocidas. Entre otros, el cambio supondrá una mayor intensificación agraria, un aumento en el tamaño de las parcelas agrícolas, una mayor homogeneidad paisajística, la eliminación de linderos y un incremento del uso de fertilizantes y biocidas.

En el área de estudio se concentra una importante población de Cernícalo Primilla durante el periodo post-reproductor (julio, agosto y septiembre) (García 2000; Olea 2001a) ocupando varios dormideros comunales, tanto en soporte natural (árbol) como artificial (torreta eléctrica; Fig. 13) (Olea 2001a). 
Introducción

(a)

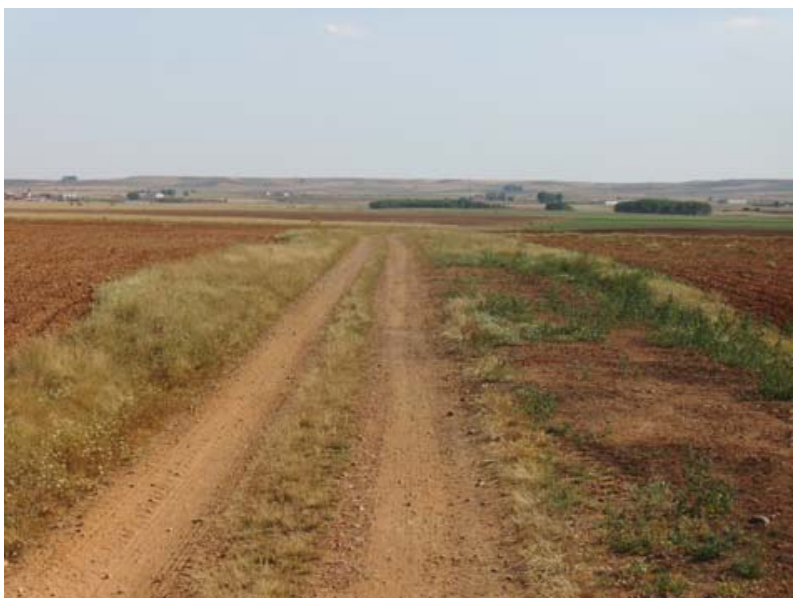

(b)

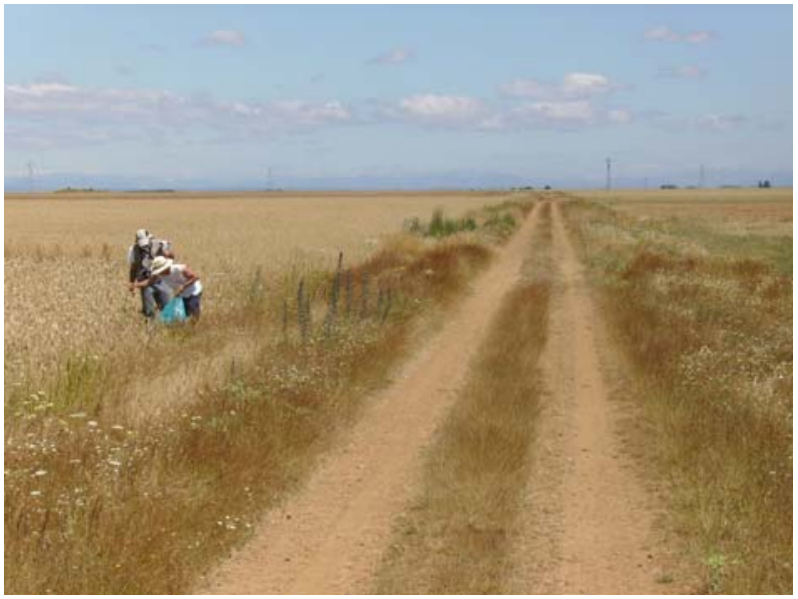

Figura 10. Detalle de los linderos (cunetas) durante el verano en el área de estudio, sureste de León (a) y (b). 
Introducción

(a)

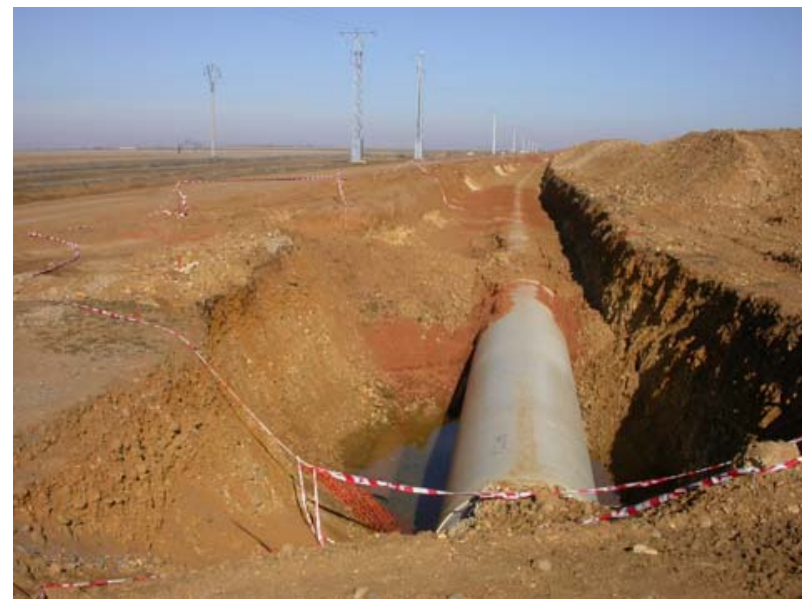

(b)

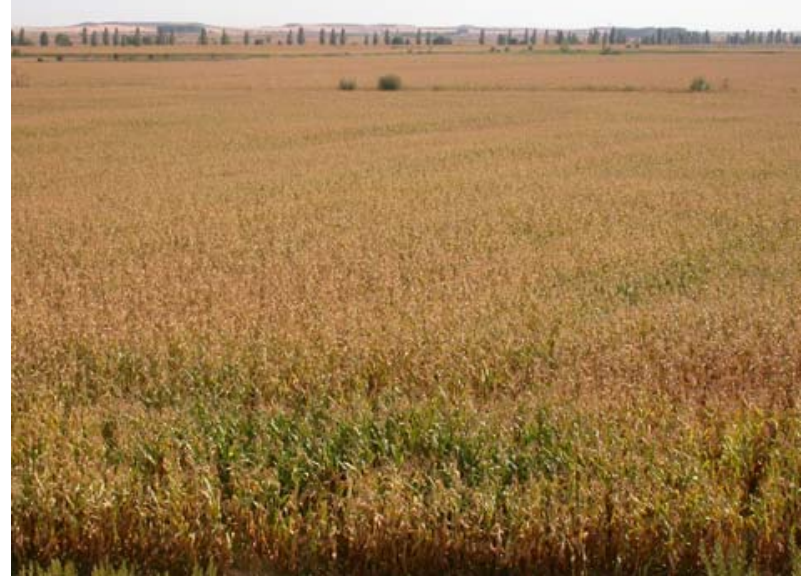

Figura 11. Instalación de infraestructuras de regadío (a) para cultivar principalmente maíz (b) en el área de estudio, sureste de León. 
Introducción

\section{Estructura de la tesis}

La presente tesis doctoral tiene como objetivo principal el estudio de la ecología y conservación del Cernícalo Primilla durante el periodo premigratorio. Específicamente se han intentado responder las siguientes preguntas:

- ¿Cómo se distribuye espacialmente la abundancia de cernícalos primillas, y qué factores determinan la distribución de esta abundancia?

- ¿Cuántos dormideros comunales estivales hay, cómo son y cuántos individuos los usan?

- ¿Cómo usan el espacio los cernícalos primillas en el entorno de los dormideros estivales?

- ¿Qué preferencias de hábitat tienen los cernícalos primillas?, ¿qué tipo de hábitats usan con más intensidad y qué hábitats seleccionan para cazar?

- ¿Qué importancia tienen para el cernícalo primilla los hábitats seminaturales (linderos y barbechos) en el paisaje agrícola durante el periodo premigratorio?

A continuación se resumen los contenidos de los capítulos que responden a las preguntas anteriores.

\section{Capítulo 1. Dormideros comunales premigratorios de Cernícalo Primilla durante el verano boreal.}

Previamente se conocía la existencia de dormideros comunales estivales en el área de estudio (Olea 2001a). Los dormideros comunales en aves son importantes desde un punto de vista ecológico y de conservación. Se ha sugerido que podrían mejorar la supervivencia de los 
individuos (Blanco \& Tella 1999) al tener un menor riesgo de depredación y una mayor eficiencia en la búsqueda de alimento (Beauchamp 1999). Algunos estudios indican además que los dormideros pueden facilitar el establecimiento de relaciones sociales con otros individuos de la especie, teniendo implicaciones en la regulación y viabilidad de las poblaciones de aves (Blanco et al. 1993; Blanco \& Tella 1999) y en la conservación de algunas especies de rapaces (Donázar et al. 1996). En el Cernícalo Primilla, la información sobre dormideros comunales estivales era muy escasa. En este capítulo abordamos un estudio en el cual localizamos todos los dormideros comunales dentro del área de estudio, los describimos y determinamos la variación temporal en la abundancia de cernícalos que los usan (Fig. 12). Conocer los dormideros y su uso por el Primilla nos permitió conocer la población premigratoria en el área, la cual es varias veces superior a la población reproductora, apoyando los resultados de dispersión juvenil (Olea 2001b). Finalmente discutimos la importancia que estos lugares pueden tener en la ecología y conservación del Cernícalo Primilla.

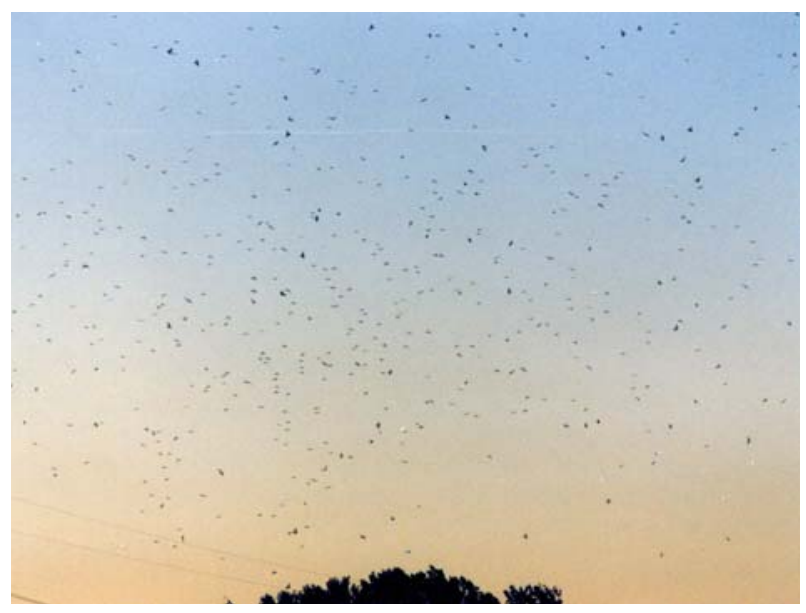

Figura 12. Grupo de cernícalos primillas momentos antes de entrar al dormidero comunal estival al atardecer. 
Introducción

(a)

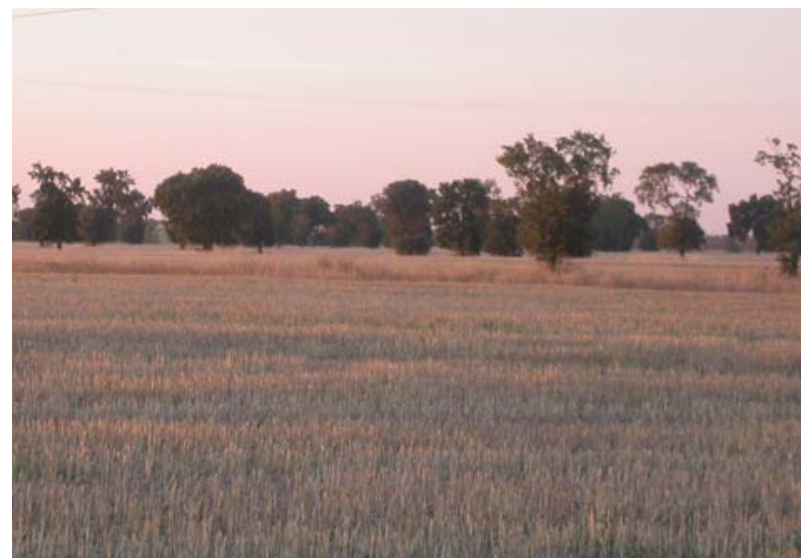

(b)

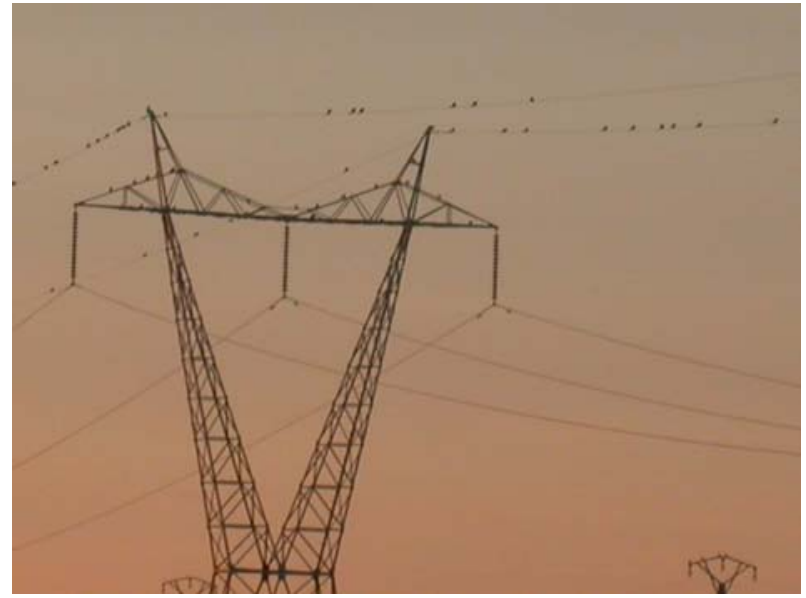

Figura 13. Dormideros estivales de Cernícalo Primilla ubicados en diferentes substratos, tanto (a) naturales (árboles) como (b) artificiales (torres de alta y baja tensión) en el área de estudio, sureste de la provincia de León.

Capítulo 2. Preferencias de hábitat del Cernícalo Primilla durante el verano

El estudio de los requerimientos de hábitat de una especie permite comprender su biología e incrementar la eficacia de los programas de gestión y conservación, garantizando así su supervivencia (Steenhof et 
Introducción

al. 1984; Blanco \& Tella 1999). En el Cernícalo Primilla no existen trabajos que analicen sus necesidades de hábitat durante el periodo premigratorio. Este capítulo aporta información básica sobre sus requerimientos de hábitat, considerados críticos a la hora de desarrollar planes de gestión eficaces. Para ello usamos modelos de selección de hábitat del Cernícalo Primilla.

El capítulo 2.1 (análisis y modelado de la distribución espacial de la abundancia del Cernícalo Primilla durante el verano: el papel de la autocorrelación espacial) es el primero en explorar la relación Cernícalo Primilla-hábitat durante el verano. Se describe y se analiza el patrón espacial de la abundancia de cernícalos medida a una resolución de $4 \mathrm{~km}$ y usando análisis de autocorrelación espacial (índice de Moran, Legendre \& Legendre 1998). El objetivo fue determinar los factores a escala de paisaje que estaban determinando la abundancia de cernícalos primillas en el periodo premigratorio. Los factores ambientales fueron medidos usando Sistemas de Información Geográfica (SIG) a diferentes extensiones espaciales. Para modelar la abundancia se emplearon modelos lineales generalizados (GLM; Guisan et al. 2002) complementados con análisis de partición jerárquica (Mac Nally 2000)] que tuvieron en cuenta la multicolinealidad entre las variables explicativas, es decir correlación entre ellas, y la localización espacial de los datos, mediante análisis de la autocorrelación espacial.

En el capítulo 2.2 (importancia de las áreas premigratorias en la conservación del Cernícalo Primilla: uso del espacio y selección de hábitat durante el periodo premigratorio) se presenta información más detallada sobre el uso del espacio en torno a los dormideros y la selección de hábitat de individuos empleando la radio-telemetría (Kenward 2001). Para ello, i) se han estudiado los movimientos de individuos equipados con radioemisores (Fig. 14) durante el periodo premigratorio, ii) se han determinado sus áreas de campeo y áreas usadas intensamente teniendo en cuenta la autocorrelación de las radiolocalizaciones (Katajisto \& Moilanen 2006), y iii) se ha evaluado la selección de hábitat a múltiples escalas espaciales teniendo en cuenta la intensidad de uso para cada tipo de hábitat (Aebischer et al. 1993; Millspaugh et al. 2006). Los tipos de hábitat usados en este análisis han sido medidos tanto a escala de paisaje (por ejemplo área agrícola y arbolado) como a una escala más fina (por ejemplo tipos de cultivos). 
Introducción

a)

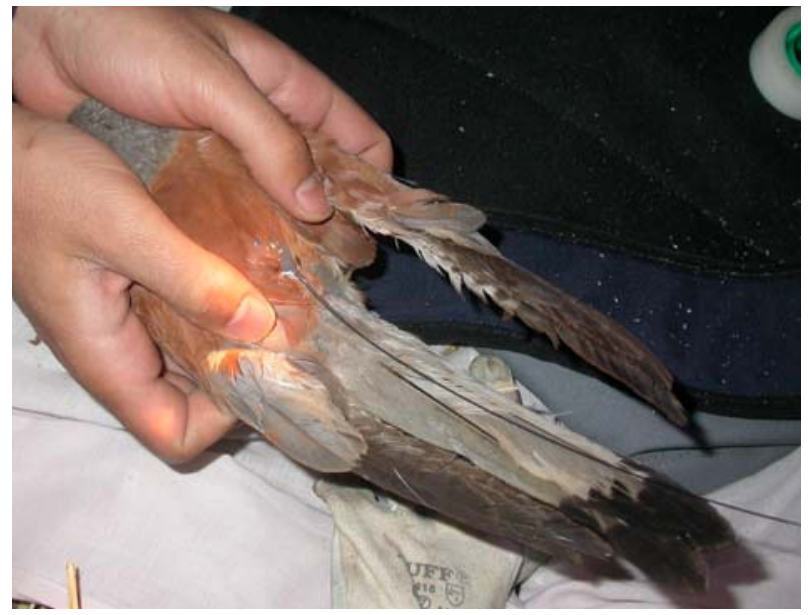

b)



Figura 14. Macho de Cernícalo Primilla con un radio-emisor equipado dorsalmente mediante harnés (a) y equipo de radio-seguimiento $(b)$.

En el capítulo 2.3 (el papel del barbecho en el uso del hábitat por el Cernícalo Primilla durante el periodo premigratorio: implicaciones en la conservación de la abolición del barbecho obligatorio) se ha examinado el papel que tiene el barbecho en el uso del hábitat del Cernícalo Primilla durante durante el periodo premigratorio y se ha evaluado el potencial efecto de la eliminación de la obligación del barbecho obligatorio, aprobada recientemente por la Comisión Europea en el marco del "Health Check" de la PAC (Política Agraria Comunitaria, European Commission 
2009). De acuerdo con los resultados obtenidos, se pone de manifiesto la importancia que tienen las ayudas agroambientales en las áreas premigratoria para la conservación del Cernícalo primilla.

En el capítulo 2.4 (selección de hábitat de caza por el Cernícalo Primilla Falco naumanni durante el periodo premigratorio) se examina la selección de hábitat usado para cazar durante dos veranos consecutivos (2001 y 2002). La selección de este hábitat puede diferir entre periodos, como ha sido observado en algunas especies coloniales de aves (Blanco \& Tella 1999), incluido el Cernícalo Primilla (por ejemplo entre invierno y periodo de cría, Tella \& Forero 2000). En el caso del Cernícalo Primilla, esta información es desconocida para el periodo premigratorio.

Adicionalmente se ha llevado a cabo un estudio (ver anexo) no incluido en los dos capítulos anteriores. Este estudio (implicaciones en la conservación y gestión ambiental del uso del módulo estadístico de partición jerárquica) se centra en el uso de la partición jerárquica, un novedoso análisis estadístico empleado en los capítulos 2.1 y 2.3. La partición jerárquica es un método analítico de regresión múltiple usado para identificar los factores causales más probables evitando posibles problemas de multicolinealidad entre ellos (Mac Nally 2000). Este método es cada vez más usado en ecología y conservación bien como herramienta principal o como complementaria a los análisis de regresión múltiple (por ejemplo, GLM). El módulo informático gratuito ("hier.part package" Walsh \& Mac Nally 2004) del programa estadístico R permite realizar de forma rutinaria este análisis. Sin embargo, este módulo produce, según sus autores, un pequeño error de redondeo cuando se usan más de 9 variables (Walsh \& Mac Nally 2007). Durante la aplicación de esta técnica estadística (véase arriba) para el análisis de hábitat del Cernícalo Primilla, obtuvimos resultados muy diferentes en función del número y el orden de las variables usadas. Por ello, nos propusimos analizar la robustez de este módulo examinando la variación potencial de resultados obtenidos en relación al número y orden de las variables incluidas en los análisis. Para ello, se han usado tanto simulaciones numéricas como datos reales de Cernícalo Primilla. Los resultados obtenidos indican que el módulo produce resultados muy inconsistentes cuando se usan más de 9 variables en el análisis. Las implicaciones que tiene el uso de este módulo en la conservación y gestión ambiental son puestas de manifiesto. 
Introducción

\section{Referencias}

Aebischer, N.J., Robertson, P.A. \& Kenward, R.E. 1993. Compositional Analysis of Habitat Use from Animal Radio-Tracking Data. Ecology 74, 1313-1325.

Anders, A.D., Faaborg, J. \& Thompson, F.R. 1998. Postfledging dispersal, habitat use, and home-range size of juvenile Wood Thrushes. Auk 115, 349-358.

Anderson, P.C., Kok, O.B. \& Erasmus, B.H. 1999. Diet, body mass and condition of Lesser Kestrels Falco naumanni in South Africa. Ostrich 70, 112-116.

Aparicio, J.M. \& Bonal, R. 2002. Effects of food supplementation and habitat selection on timing of Lesser Kestrel breeding. Ecology 83, 873-877.

Atienza, J.C. \& Tella, J.L. 2004. Cernícalo Primilla, Falco naumanni, In Libro rojo de las aves de España. eds A. Madroño, C. González, J.C. Atienza, p. 452 p. Dirección general para la Biodiversidad-SEO/BirdLife, Madrid. España.

Baker, R.R. 1993. The function of postfledging exploration - a pilot-study of 3 species of passerines ringed in Britain. Ornis Scandinavica 24, 71-79.

Beauchamp, G. 1999. The evolution of communal roosting in birds: origin and secondary losses. Behavioral Ecology 10, 675-687.

Bernis, F. 1980. La migración de las aves en el estrecho de Gibraltar : época posnuncial. Volumen I. Aves planeadoras. Cátedra de Zoología de Vertebrados. Universidad Complutense, Madrid.

Biber, J.P. 1996. International Action Plan for the Lesser Kestrel (Falco naumanni). Cambridge. UK.

BirdLife International 2009a. Falco naumanni, In 2009 IUCN Red List of Threatened Species. Available at http://www.redlist.org. Accessed 03 Feb 2009. ed. IUCN.

BirdLife International 2009b. Falco naumanni, In Species factsheet: Falco naumanni. Downloaded from http://www.birdlife.org on 10/2/2009. ed. IUCN.

Blanco, G., Fargallo, J.A. \& Cuevas, J.A. 1993. Seasonal variations in numbers and levels of activity in a communal roost of Choughs Pyrrhocorax pyrrhocorax in a central Spain. . Avocetta 17, 41-44. 
Blanco, G. \& Tella, J.L. 1999. Temporal, spatial and social segregation of redbilled choughs between two types of communal roost: a role for mating and territory acquisition. Animal Behaviour 57, 1219-1227.

Bonal, R. \& Aparicio, J.M. 2008. Evidence of prey depletion around lesser kestrel Falco naumanni colonies and its short term negative consequences. Journal of Avian Biology 39, 189-197.

Bustamante, J. 1997. Predictive models for lesser kestrel Falco naumanni distribution, abundance and extinction in southern Spain. Biological Conservation 80, 153-160.

Bustamante, J. \& Negro, J.J. 1994. The postfledging dependence period of the Lesser Kestrel (Falco naumanni) in Southwestern Spain. Journal of Raptor Research 28, 158-163.

Cramp, S. \& Simmons, K.E.L. 1980. The Birds of the Western Paleartic. Vol II. Oxford University Press, Oxford.

Donázar, J.A., Ceballos, O. \& Tella, J.L. 1996. Communal roosts of Egyptian Vulture (Neophron percnopterus): dynamics and implications for the species conservation, In Biología y Conservación de las Rapaces Mediterráneas. eds J. Muntaner, J. Mayol, pp. 189-201. SEO/BIRDLIFE (Monografías $n^{\circ} 4$ ), Palma de Mallorca.

Donázar, J.A., Negro, J.J. \& Hiraldo, F. 1993. Foraging habitat selection, land-use changes and population decline in the lesser kestrel Falco naumanni. Journal of Applied Ecology 30, 515-522.

European Commission 2009. Agriculture and Rural Development, In http://ec.europa.eu/agriculture/index en.htm Downloaded on 02 Feb 2009.

Forero, M.G., Tella, J.L., Donázar, J.A. \& Hiraldo, F. 1996. Can interspecific competition and nest site availability explain the decrease of lesser kestrel Falco naumanni populations? Biological Conservation 78, 289293.

Franco, A. \& Andrada, J.A. 1977. Alimentación y selección de presa en Falco naumanni. Ardeola 23, 137-187.

Franco, A.M.A. \& Sutherland, W.J. 2004. Modelling the foraging habitat selection of lesser kestrels: conservation implications of European Agricultural Policies. Biological Conservation 120, 63-74.

García, J. 2000. Dispersión premigratoria del Cernícalo Primilla Falco naumanni en España. Ardeola 47, 197-202.

García, J.T., Morales, M.B., Martínez, J., Iglesias, L., De la Morena, E.G., Suárez, F. \& Viñuela, J. 2006. Foraging activity and use of space by Lesser 
Introducción

Kestrel Falco naumanni in relation to agrarian management in central Spain. Bird Conservation International 16, 83-95.

González, J.I. \& Merino, M. 1990. El Cernícalo Primilla (Falco naumanni) en la Península Ibérica: situación, problemática y aspectos biológicos. ICONA, Madrid.

Guisan, A., Edwards, T.C. \& Hastie, T. 2002. Generalized linear and generalized additive models in studies of species distributions: setting the scene. Ecological Modelling 157, 89-100.

Heredia, B., Rose, L. \& Painter, M. 1996. Globally threatened birds in Europe. Action plans. Council of Europe Publishing. Birdlife International, Strasbourg.

Hiraldo, F., Bustamante, J. \& Donázar, J.A. 1995. On raptor roadside surveys in Western Turkey and Eastern Greece. Journal of Raptor Research 29, 145-145.

Hiraldo, F., Donazar, J.A. \& Negro, J.J. 1994. Effects of tail-mounted radio-tags on adult Lesser Kestrels. Journal of Field Ornithology 65, 466-471.

Hiraldo, F., Negro, J.J. \& Donázar, J.A. 1991. Aborted polygyny in the Lesser Kestrel Falco naumanni (Aves, Falconidae). Ethology 89, 253-257.

Hiraldo, F., Negro, J.J., Donázar, J.A. \& Gaona, P. 1996. A demographic model for a population of the endangered lesser kestrel in southern Spain. Journal of Applied Ecology 33, 1085-1093.

Katajisto, J. \& Moilanen, A. 2006. Kernel-based home range method for data with irregular sampling intervals. Ecological Modelling 194, 405-413.

Kenward, R. 2001. A manual for wildlife radio tagging. Academic Press, San Diego.

Kopij, G. 2002. Food of the Lesser Kestrel (Falco naumanni) in its winter quarters in South Africa. Journal of Raptor Research 36, 148-152.

Legendre, P. \& Legendre, L. 1998. Numerical ecology. Developments in environmental modelling, vol. 20. Elsevier, Amsterdam.

Limiñana, R., Soutullo, A., López-López, P. \& Urios, V. 2008. Pre-migratory movements of adult Montagu's Harriers Circus pygargus. Ardea 96, 8190.

Liven-Schulman, I., Leshem, Y., Alon, D. \& Yom-Tov, Y. 2004. Causes of population declines of the Lesser Kestrel Falco naumanni in Israel. Ibis $146,145-152$. 
Mabey, S.E. \& Watts, B.D. 2000. Conservation of landbird migrants: addressing local policy. Studies in Avian Biology 20, 99-108.

Mac Nally, R. 2000. Regression and model-building in conservation biology, biogeography and ecology: The distinction between and reconciliation of 'predictive' and 'explanatory' models. Biodiversity and Conservation 9, 655-671.

MAPA 2002. Plan Nacional de Regadíos, In http://www.mapa.es/es/desarrollo/pags/pnr/principal.htm Downloaded on 02 Feb 2002.

Millspaugh, J.J., Nielson, R.M., McDonald, L., Marzluff, J.M., Gitzen, R.A., Rittenhouse, C.D., Hubbard, M.W. \& Sheriff, S.L. 2006. Analysis of resource selection using utilization distributions. Journal of Wildlife Management 70, 384-395.

Morales, M.B., Jesus Garcia, T., Garcia de la Morena, E.L., Arroyo, B. \& Suarez, F. 2006. 'Summer trips', or how some birds cope with Mediterranean seasonality. Journal of Ornithology 147, 213-213.

Negro, J.J. 1991. Problemas de identificación. El cernícalo vulgar y el primilla. La Garcilla, 5-7.

Negro, J.J., de la Riva, M. \& Bustamante, J. 1991. Patterns of winter distribution and abundance of Lesser Kestrel (Falco naumanni) in Spain. Journal of Raptor Research 25, 30-35.

Negro, J.J., Donázar, J.A. \& Hiraldo, F. 1992. Copulatory behaviour in a colony of Lesser Kestrels sperm competition and mixed reproductive strategies. Animal Behaviour 43, 921-930.

Negro, J.J., Donázar, J.A. \& Hiraldo, F. 1993. Home range of lesser kestrels (Falco naumanni) during the breeding season, In Biology and conservation of small falcons. eds M.K. Nicholls, R. Clarke, pp. 144-150. The Hawk and Owl Trust, Canterbury, London.

Negro, J.J. \& Hiraldo, F. 1993. Nest-site selection and breeding success in the lesser kestrel Falco naumanni. Bird Study 40, 115-119.

Negro, J.J., Hiraldo, F. \& Donázar, J.A. 1997. Causes of natal dispersal in the lesser kestrel: inbreeding avoidance or resource competition? Journal of Animal Ecology 66, 640-648.

Olea, P. 2001a. Contribución al conocimiento de la ecología de tres especies de aves coloniales : Buitre Leonado Gyps fulvus, Cernícalo Primilla Falco naumanni y Graja Corvus frugilegus. PhD Thesis, Universidad de León, Spain. 
Introducción

Olea, P.P. 2001b. Postfledging dispersal in the endangered Lesser Kestrel Falco naumanni. Bird Study 48, 110-115.

Olea, P.P. \& García, J. 1997. Distribución y tamaño de la población reproductora de Cernícalo Primilla Falco naumanni en la provincia de León. Aegypius $14,39-40$.

Olea, P.P., Vera, R., De Frutos, A. \& Robles, H. 2004. Premigratory communal roosts of the Lesser Kestrel in the boreal summer. Journal of Raptor Research 38, 278-282.

Ortego, J., Calabuig, G., Aparicio, J. \& Cordero, P.J. 2008. Genetic consequences of natal dispersal in the colonial lesser kestrel. Molecular Ecology 17, 2051-2059.

Penas, A., García, M.E., Herrero, L., Puente, E. \& De Godos, M. 1995. Atlas del medio natural de la provincia de León. Instituto Tecnológico Geominero de España y Diputación de León, Madrid.

Penteriani, V., Delgado, M.M., Maggio, C., Aradis, A. \& Sergio, F. 2005. Development of chicks and predispersal behaviour of young in the Eagle Owl Bubo bubo. Ibis 147, 155-168.

Petit, D.R. 2000. Habitat use by landbirds along nearctic-neotropical migration routes: Implications for conservation of stopover habitats. Studies in Avian Biology 20, 15-33.

Petit, S. \& Firbank, L. 2006. Predicting the risk of losing parcels of semi-natural habitat to intensive agriculture. Agriculture Ecosystems \& Environment $115,277-280$.

Pouillard, E. 2007. Estudio del impacto de la intensificación agraria sobre la biodiversidad: indicadores de la intensificación agrícola en las pseudoestepas cerealistas del noroeste de España. Master: Sciences et Technologies. Université de Montpellier II, Montpellier, Francia.

Rappole, J.H. \& Ballard, K. 1987. Postbreeding Movements of Selected Species of Birds in Athens, Georgia. Wilson Bulletin 99, 475-480.

Rivera, J.H.V., McShea, W.J., Rappole, J.H. \& Haas, C.A. 1999. Postbreeding movements and habitat use of adult wood thrushes in northern Virginia. Auk 116, 458-466.

Rivera, J.H.V., Rappole, J.H., McShea, W.J. \& Haas, C.A. 1998. Wood thrush postfledging movements and habitat use in northern Virginia. Condor $100,69-78$.

Rodríguez, C. \& Bustamante, J. 2003. The effect of weather on lesser kestrel breeding success: can climate change explain historical population declines? Journal of Animal Ecology 72, 793-810. 
Introducción

Rodríguez, C., Johst, K. \& Bustamante, J. 2006. How do crop types influence breeding success in lesser kestrels through prey quality and availability? A modelling approach. Journal of Applied Ecology 43, 587-597.

Rodríguez, C. \& Wiegand, K. 2009. Evaluating the trade-off between machinery efficiency and loss of biodiversity-friendly habitats in arable landscapes: The role of field size. Agriculture Ecosystems \& Environment 129, 361366.

Sánchez, I. 1997. Cernícalo Primilla, In Atlas de las aves de España (1975-1995). ed. F.J. Purroy, pp. 128-129. Lynx Edicions, Barcelona.

Sergio, F., Marchesi, L., Pedrini, P., Ferrer, M. \& Penteriani, V. 2004. Electrocution alters the distribution and density of a top predator, the eagle owl Bubo bubo. Journal of Applied Ecology 41, 836-845.

Serrano, D., Forero, M.G., Donázar, J.A. \& Tella, J.L. 2004. Dispersal and social attraction affect colony selection and dynamics of lesser kestrels. Ecology 85, 3438-3447.

Serrano, D. \& Tella, J.L. 2003. Dispersal within a spatially structured population of lesser kestrels: the role of spatial isolation and conspecific attraction. Journal of Animal Ecology 72, 400-410.

Serrano, D., Tella, J.L., Donazar, J.A. \& Pomarol, M. 2003. Social and individual features affecting natal dispersal in the colonial Lesser Kestrel. Ecology 84, 3044-3054.

Serrano, D., Tella, J.L., Forero, M.G. \& Donázar, J.A. 2001. Factors affecting breeding dispersal in the facultatively colonial lesser kestrel: Individual experience vs. conspecific cues. Journal of Animal Ecology 70, 568-578.

Siegfried, W.R. \& Skead, D.M. 1971. Status of the Lesser Kestrel in South Africa. Ostrich 42, 1-4.

Steenhof, K., Kochert, M.N. \& Moritsch, M.Q. 1984. Dispersal and migration of southwestern Idaho raptors. Journal of Field Ornithology 55, 357-368.

Tella, J.L. 2004. Situación de las poblaciones de Cernícalo Primilla: pasado, presente, y necesidades para el futuro, In Actas del VI Congreso Nacional sobre el Cernícalo Primilla. ed. Gobierno de Aragón, p. 28. Gobierno de Aragón. Departamento de Medio Ambiente, Zaragoza, Spain.

Tella, J.L. \& Forero, M.G. 2000. Farmland habitat selection of wintering lesser kestrels in a Spanish pseudosteppe: implications for conservation strategies. Biodiversity and Conservation 9, 433-441.

Tella, J.L., Forero, M.G., Donázar, J.A., Negro, J.J. \& Hiraldo, F. 1997. Nonadaptive adoptions of nestlings in the colonial lesser kestrel: proximate 
causes and fitness consequences. Behavioral Ecology and Sociobiology 40, 253-260.

Tella, J.L., Forero, M.G., Hiraldo, F. \& Donázar, J.A. 1998. Conflicts between lesser Kestrel conservation and European agricultural policies as identified by habitat use analyses. Conservation Biology 12, 593-604.

Tucker, G.M. \& Heath, M.F. 1994. Birds in Europe: their conservation status. BirdLife International, Cambridge.

Ursúa, E. \& Tella, J.L. 2001. Unusual large communal roosts of Lesser Kestrel in two electric substations of Northern Spain: implications for the conservation of Spanish population, In Abstracts of the $4^{\text {th }}$ Eurasian Congress on Raptors. eds J. Bustamante, G. Crema, E. Casado, J. Seoane, C. Alonso, C. Rodríguez, M. de Lucas, G. Janss, p. 188. Estación Biológica de Doñana and Raptor Research Foundation, Sevilla, Spain.

Vlachos, C., Bakaloudis, D., Chatzinikos, E., Papadopoulos, T. \& Tsalagas, D. 2003. Aerial hunting behaviour of the Lesser Kestrel Falco naumanni during the breeding season in Thessaly (Greece). Acta Ornithologica 38, 129-134.

Walsh, C. \& Mac Nally, R. 2004. "The hier.part Package" version 1.0. Hierarchical Partitioning. Documentation for R: A language and environment for statistical computing. R Foundation for statistical Computing, http://www.rproject.org.

Walsh, C. \& Mac Nally, R. 2007. "The hier.part Package" version 1.0-2. Hierarchical Partitioning. Documentation for $\mathrm{R}$ : A language and environment for statistical computing. $R$ Foundation for statistical Computing, Vienna, Austria. http://www.rproject.org. 


\section{Capítulo 1}

\section{Dormideros comunales premigratorios de Cernícalo Primilla durante el verano boreal}

Premigratory communal roosts of the Lesser Kestrel in the boreal summer. Olea, P.P., Vera, R., De Frutos, A.\& Robles, H. 2004. Journal of Raptor Research 38, 278-282. 


\section{Resumen}

Existe poca información sobre dormideros comunales estivales de Cernícalo Primilla (Falco naumanni) en la región Paleártica. Estudiamos los dormideros comunales de Cernícalo Primilla durante los veranos de 1998, 2001, y 2002 en un área agrícola $\left(384 \mathrm{~km}^{2}\right.$ con 23 parejas reproductoras) en el noroeste de España. Los dormideros se buscaron intensamente cada año por todo el área de estudio y se registró el número de cernícalos primillas que usaron los dormideros. Los dormideros se ubicaron en diferentes substratos, tanto naturales (árboles) como artificiales (torres de alta y baja tensión). Se localizaron cuatro dormideros en 1998 (96-355 aves), cinco en 2001 (7-750 aves) y cuatro en 2002 (360-666 aves). Los dos dormideros con mayor número de individuos fueron usados durante los tres años de estudio. El número máximo de individuos en los dos dormideros más grandes fue de 925 aves en 2001 y 761 en 2002. El número de cernícalos primillas alcanzó el máximo en Agosto, probablemente por la llegada de individuos de otras áreas, y descendió en Septiembre, coincidiendo con la migración. La gran concentración de individuos y la fidelidad a los lugares usados como dormideros sugiere un importante papel de estas áreas en la ecología y conservación del Cernícalo Primilla. 


\begin{abstract}
Communal roosting of Lesser Kestrels (Falco naumanni) is not well documented during summer in the Palearctic region. We studied the occurrence of communal roosts of Lesser Kestrels in a farmland area (384 $\mathrm{km} 2$ with 23 breeding pairs) in northwestern Spain during the summers of 1998,2001 , and 2002. We attempted to locate all roosts in the study area each year and counted individuals entering the roosts at sunset. Roosts occurred in different substrates, including natural sites (trees) and manmade structures (i.e., power pylons). We located four roosts of Lesser Kestrels in 1998 (96--355 individuals), five in 2001 (7--750 individuals), and four in 2002 (360--666 individuals). Two roosts holding the highest number of kestrels were used during the $3 \mathrm{yr}$ of study. The maximum number of Lesser Kestrels roosting in the two larger roosts was 925 birds in 2001 and 761 birds in 2002. The number of Lesser Kestrels peaked in August, possibly because of the arrival of individuals from other areas, and decreased in September, when the kestrels started their migration. The large concentration of falcons and their fidelity to roost sites suggests these areas are important to the ecology and conservation of Lesser Kestrels.
\end{abstract}

Keywords: Lesser Kestrel; Falco naumanni; premigratory aggregations; communal roosts. 


\section{Introduction}

The Lesser Kestrel (Falco naumanni) is a small migratory falcon breeding in the Palearctic and wintering mainly in Africa (Siegfried and Skead 1971, Cramp and Simmons 1980). This species is considered to be a threatened species listed as Vulnerable (BirdLife International 2002). Although many aspects of their breeding biology have been studied (e.g., Negro et al. 1992, Donázar et al.1993, Hiraldo et al. 1996, Tella et al. 1996a, 1996b, and 1997) there is little known about the post-fledging period of this species (but see Bustamante and Negro 1994, García 2000, Olea 2001a). This period can be particularly critical for the survival of the juvenile falcons because recently fledged birds have little experience in foraging, and in avoiding predators and human activities (Anders et al. 1998). During the post-fledging period, Lesser Kestrels seem to increase significantly in their abundance in some areas in northern Spain, where breeding populations are small or nonexistent (e.g., Llamas et al. 1987, Jubete 1997, Román 1998, Olea 2001b) and gather in communal roosts (Olea 2001b, Ursúa and Tella 2001).

Avian communal roosting is thought to provide survival benefits (Blanco and Tella 1999) in terms of decreased predation risk and increased foraging efficiency (Beauchamp 1999). Some evidence also suggests that such roosts could facilitate social relationships with implications in the regulation and viability of bird populations (Blanco et al. 1993, Blanco and Tella 1999) and in the conservation of some raptor species (Donázar et al. 1996). To manage and conserve a bird population, it is necessary to understand the requirements and the limiting factors of a population throughout the annual period (Steenhoff et al. 1984). For Lesser Kestrels, information on summer communal roosts is incomplete. The species has been studied during winter in Spanish areas (Negro et al. 1991) as well as in Africa (austral summer; Siegfried and Skead 1971, Kopij 2002). To our knowledge, the only published information on Lesser Kestrel' roosts during the summer in the Palearctic comes from Spain and Italy, and consists of anecdotal records of two roosts (Tejero et al. 1982 and Aparicio 1990, respectively) and on the monitoring of birds at four roosts during a single summer (Palumbo 1997, 
Olea 2001b, Ursúa and Tella 2001). Here, we examine the use of communal roosts by Lesser Kestrels in northwestern Spain during three summers. We describe roost site characteristics and examine numbers and temporal variation of roosting Lesser Kestrels.

\section{Methods}

Communal roosts were located in the province of León, northwestern Spain, at about $800 \mathrm{~m}$ above sea level, between the towns of Santas Martas and Sahagún $\left(42^{\circ} 25^{\prime}--42^{\circ} 17^{\prime} \mathrm{N}\right.$, and $5^{\circ} 23^{\prime}-5^{\circ} 06^{\prime} \mathrm{W} ; 11.7^{\circ} \mathrm{C}$ annual mean temperature and $486 \mathrm{~mm}$ rainfall). The study area covers $384 \mathrm{~km} 2$ devoted to cereal crops. This area was selected because communal roosting was observed previously (Olea, 2001b, pers. obs.). In 2002, we documented 23 breeding pairs of Lesser Kestrels in the study area. The landscape was flat and open, with practically no trees. The area is broken up by a number of small seasonal streams flowing in a north-south direction. When this study was conducted, the fields had been partially harvested and the area was mostly dominated by stubble and fallow fields ( $74 \%$ of the area). The area is also crossed by a recently-built highway.

Roost Site detection. An effort was made to find all roosts in the study area. We looked for roost sites between 20-26 August 1998. In 2001 and 2002 the search for roosts began on 25 July and 1 July, respectively. We first checked the roosts used by Lesser Kestrel in previous years. Next, we searched for new roosts in the area until the end of the summer. Several observers with binoculars (8x) and telescope (20-60x) were distributed across the area at the best vantage points. Roosts were located during late afternoon, because during this period the Lesser Kestrels tended to gather around "staging" areas near roosts. These aggregations were fairly conspicuous and easy to detect. From these sites, kestrels progressively moved towards the roost sites about an hour before sunset.

Monitoring of Roosting Birds. We counted birds at the roosts between 26 August and 26 September in 1998 (every 3--7 d, 7 monitoring d), between 25 July and 10 October in 2001 (every 1--17 d, 14 monitoring d) and between 1 July and 9 October in 2002 (every 1--11 d, 23 monitoring d). In 1998 and 2001, we began to count birds at roosts on 26 August and 25 July, respectively, after the Lesser Kestrels began using roosts. For 
this reason, in 2002 we initiated monitoring several weeks before the previous years to determine accurately the date when Lesser Kestrels started to use the roosts.

Except in 1998, we tried to census Lesser Kestrels using all roosts simultaneously. Only one roost was monitored in 1998; in 2001 and 2002, the two largest and more-stable roosts were monitored during the entire study period. Observation sites were at ground level and 300--600 m away from the roosts. Individuals were counted using binoculars and 20-$60 \times$ spotting scopes. To avoid bias in the counting between observers, the same persons monitored the same roosts. Although this does not eliminate potential biases among roosts, counts of Lesser Kestrels in the roosts were facilitated by their behavior. Specifically, before roosting, kestrels perched on powerlines, where time was spent preening, or bathed in the sand. Thus, we believe that the census of kestrels was reliable.

We counted individuals going to roosts in 2.5-5 min intervals from 30 min before sunset until all individuals entered the roost. The highest evening count was used as the roost count for that day. In roost $A$, we censused Lesser Kestrels when perching on powerlines close to the small and scattered group of evergreen oaks trees (Quercus ilex), which they used as roost site (Table 1). At this roost, birds flew as singles, in pairs, or in small groups from the wires to the trees, but not in the opposite direction. This made counting kestrels relatively easy.

In 2002, we could not obtain accurate counts of Lesser Kestrels entering one of the roosts on several occasions (6 of 23 censuses) because roosting activity was erratic. Therefore, they were counted kestrels immediately following sunrise leaving the roost (from $30 \mathrm{~min}$ before sunrise until after all the kestrels left the roost).

\section{Results}

Description of the Roost Sites. In 1998, four communal roosts of Lesser Kestrels were found. Roost site A was located in a small evergreen oak forest, where Lesser Kestrels used a group of five scattered evergreen oaks 5-8 m high, and close to a road ( $<150 \mathrm{~m}$; see Table 1). Roost B, was located on three utility pylons (380 kV). More than $90 \%$ of the individuals roosted on a single pylon. Roost $\mathrm{C}$, was on three 
trees (two black locusts [Robinia pseudoacacia] and common pear [Pyrus communis]) 6-7 $\mathrm{m}$ high. Roost $\mathrm{D}$ was in a poplar (Populus sp.) plantation of $612 \mathrm{~m}^{2}$ with poplars $20-28 \mathrm{~m}$ high.

All four roosts were in the vicinity of powerlines $(<50 \mathrm{~m})$, ranging from $<45-380 \mathrm{kV}$ (Table 1), where the birds grouped, rested and preened before going to the roost. The shortest distance between roost sites was 6 $\mathrm{km}$ (between roosts $A$ and $C$ ), and the longest, $17 \mathrm{~km}$ (between roosts $A$ and D).

In 2001, we located four roosts, two of them were the same as in 1998 ( $A$ and D). The new two roosts were on electric poles ( $E$ on several $<45 \mathrm{kV}$ poles and $\mathrm{F}$ on $380 \mathrm{kV}$ poles). In 2002, Lesser Kestrels used roosts $A$ and $D$, but in roost $A$ the birds used a larger number of evergreen oaks in the forest than in 1998 (see above).

Change of Roost Sites within the Year. On 10-12 September 1998 some changes in the roost sites were observed: kestrels stopped using roost $B$ and roost $A$ was moved $0.5--1.5 \mathrm{~km}$ from the previous roost location. On 17--18 September 2001, the kestrels in roost D split into three groups, one stayed in roost $D$, another moved to roost $G$, and the third group of kestrels left and were not located. In 2002, the kestrels in roost D split temporally (between 27 and 29 August) in three groups, using two other nearby plantations of poplars (not included in Table 1). Later that year (between 29 August and 4 September), roost D was reused.

Roost Dynamics. In 1998, the mean number of Lesser Kestrels in roost A was 320 until 10 September; this number peaked on 29 August, with 355 individuals. The number of Lesser Kestrels decreased markedly after 10 September (particularly between 10--17 September), until 26 September, when no individuals were detected at the roost.

The abundance pattern of roosting Lesser Kestrels at roosts $A$ and $D$ varied between 2001 and 2002. During 2001, the number of birds in roost $D$ tended to be about three times higher than in roost $A$ (Fig. 1a). The maximum number of birds in roost $D$ was 750 (31 August), and 200 birds in roost $A$ (12 August). The number of Lesser Kestrels decreased markedly after 7 September in both roosts. From October, no birds were observed in the roosts. The maximum number of birds summing up both roosts, simultaneously censused, was 925 (31 August; Fig. 1a). Two other small roosts ( $E$ and $F$ ) were used in 2001 (Table 1). 


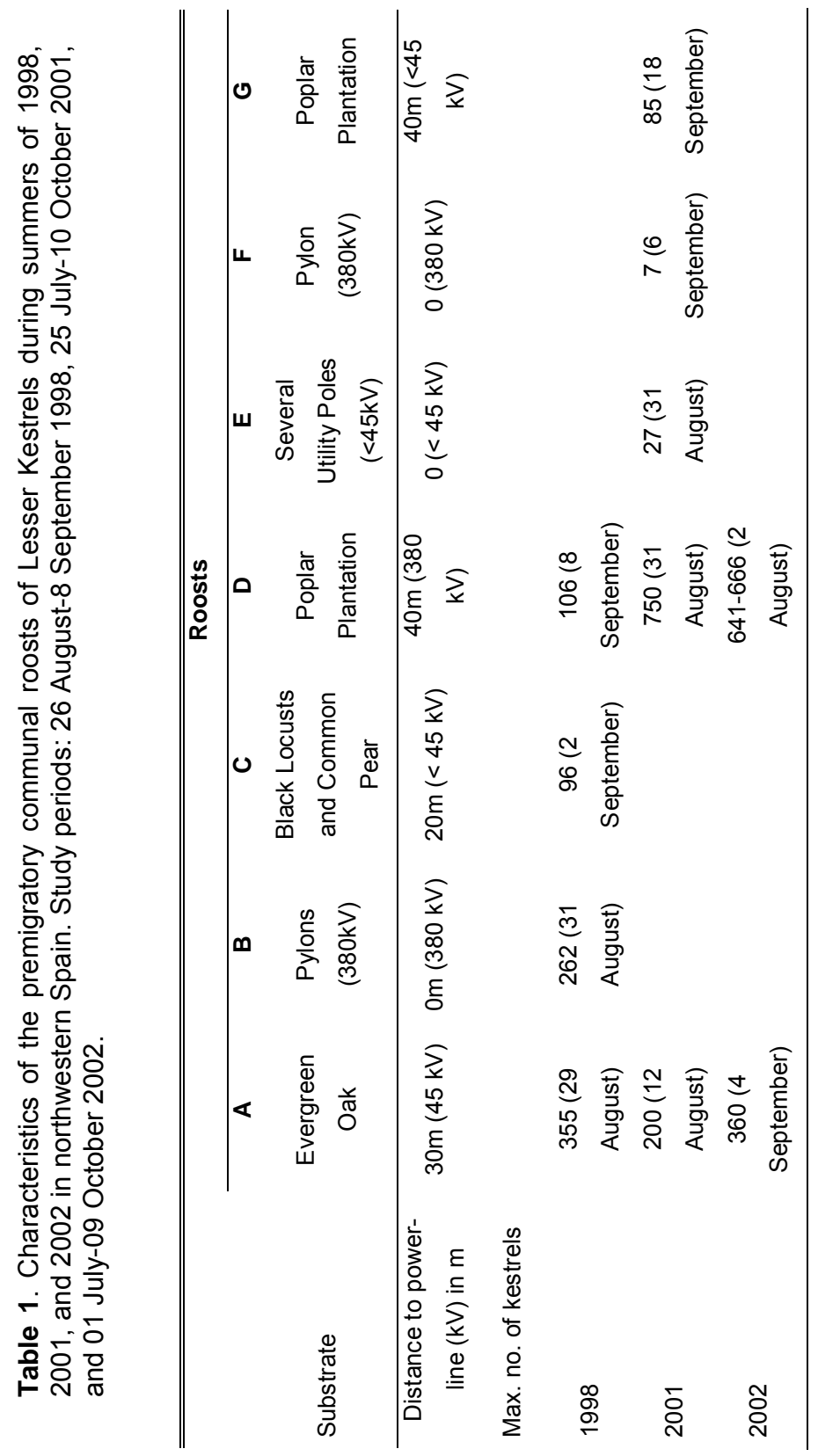


In 2002, the first birds using the roosts were observed in 15 July and 18 July in roosts $D$ and $A$, respectively (Fig. 1b). Use of the two roosts by kestrels through time during the post-fledgling period differed in 2002. Roost $D$ increased markedly until 2 August (peak $=653$ birds), while kestrels at roost A steadily increased until 4 September with 360 birds (Fig. 1b). No birds were observed in roost D on 16 September, while there were no birds in roost $A$ on 3 October. The maximum number of birds, summing up both roosts, was 761 in 2002 (7 August; Fig. 1b).

Roosting Behavior. During 2001 and 2002, the roosting behavior was different at the two primary roosts observed ( $D$ and $A$ ). At roost $D$, the birds formed generally a cloud-like flock circling above the roost ca. 10 min before entering the roost. However, at roost $A$ the birds flew directly from powerlines or the ground to roost as singles, in pairs, or in small groups. Lesser kestrels entered the roosts from sunset until ca. $30 \mathrm{~min}$ later. In 2001, Lesser Kestrels entered the roosts between 3 and $34 \mathrm{~min}$ after sunset. In 2002, Lesser Kestrels entered the roosts from $1.3 \mathrm{~min}$ before--23 min after sunset.

\section{Discussion}

In the study area, close to 1000 Lesser Kestrels used communal roosts at some pointy during the summer. Similar aggregations have been found during this period in northeastern Spain (Ursúa and Tella 2001). Because our study area had only 23 Lesser Kestrel breeding pairs in 2002 , the large population we found using roosts in summer indicates that most birds were adults or juveniles coming from other areas, as previously suggested by other authors (García 2000, Ursúa and Tella 2001) and supported with observations on post-fledging dispersal (Olea 2001a).

In our study area, Lesser Kestrel used the roosts from mid-July until late September. This temporal pattern differs somewhat from that found by Ursúa and Tella (2001) in two roosts in northeastern Spain (Navarra), where birds used the roosts from early June. This difference could be due to the fact that the Navarra roosts could be used by the local population during the breeding period, contrary to what has been observed in our study area. Another possible explanation would be that there are differences in breeding phenology in the dates of first occupancy of roosts among years. 
(a)
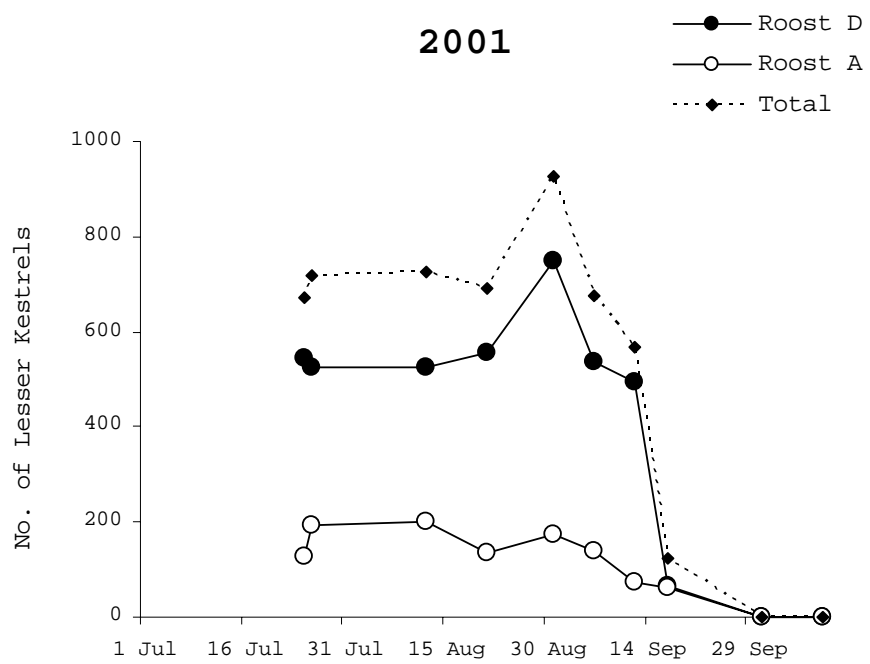

(b)

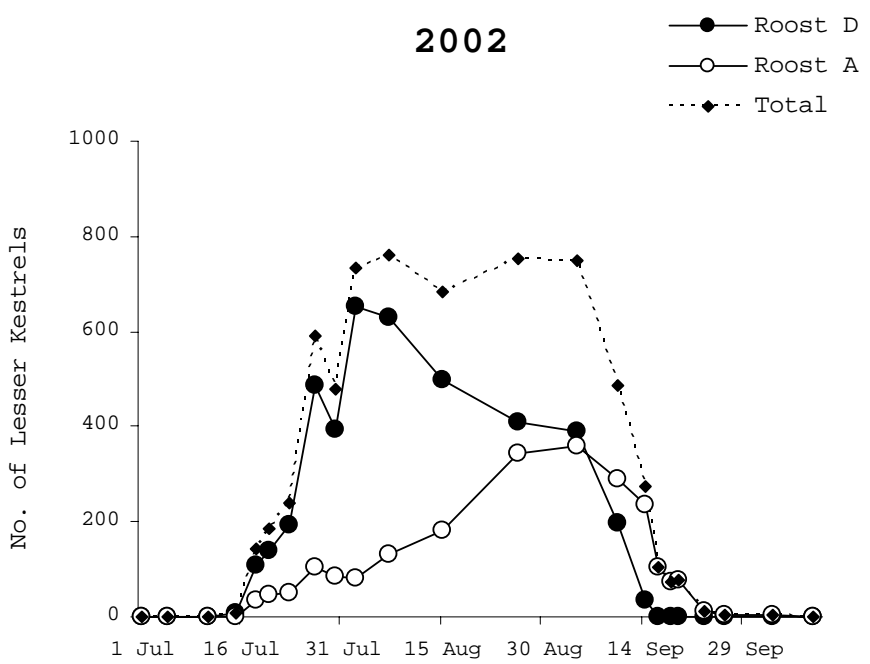

Figure 1. Seasonal variation of Lesser Kestrel abundance at roosts $A$ and $D$ and total number (sum of kestrels using roosts main roosts $A$ and D; in summer of 2001(a), and summer of 2002 (b).

The number of birds at the roosts increased from mid-July, probably due to the arrival of post-breeding individuals. The decrease in the number of Lesser Kestrels from September coincided with the migration to winter quarters (Bernis 1980), and was consistent with observations by 
Ursúa and Tella (2001). The maximum of birds, summing up the two larger roosts simultaneously censused, was reached in August in both years (Fig. 1). This agrees with what has been observed in Navarra (Ursúa and Tella 2001) and Italy (Palumbo 1997). Nevertheless, the date of the maximum number of birds varied between roosts, especially in 2002 (Fig. 1b). The cause of this difference between the roosts $A$ and $D$ is not clear, but it could be due to the fact that roost $D$ was censused at sunrise during 6 d (between 27 July and 15 August; Fig. 1b). Kopij (2002) found Lesser Kestrels arriving to the roosts several hours after sunset, therefore the number of birds counted at sunrise may be larger than at sunset. If so, the peak observed on 2 August could be due to differences in the counting procedures. However, we do not know whether Lesser Kestrels arrived after sunset counts at the roosts we studied, and if that was so, what fraction of the population it represented. On the other hand, the observed negative trend in number of birds from 7 August (counted at sunrise) was maintained, although the censuses from 15 August were carried out at sunset, suggesting that such potential bias was minimized (Fig. 1b). Alternatively, the different dynamics of roost A and D in 2002 could be due to interchange of individuals between roosts (individuals at roost $D$ switched to using roost $A$ later during the post-fledging period; Fig. 1b).

Lesser Kestrels returned to the study area year after year and were faithful in their use of communal roosts, with two roosts used at least during $3 \mathrm{yr}$, suggesting that this area could be used as a regular premigratory area. Areas occupied by a relatively high post-breeding population of Lesser Kestrel, such as our study area where the postbreeding numbers largely exceeds the breeding population, has also been found in the northern Spain (Ursúa and Tella 2001), and this could to be the case elsewhere (e.g., Jubete 1997, Román 1998). The apparent fidelity to roost sites suggests an important role for these summer areas. Aparicio (1990) and Morton (1992) have suggested that food supply is important during the period prior to migration when individuals molt and fatten, and may be a critical factor for the survival of some raptor species during dispersal (Newton 1979, Korpimäki and Lagerström 1988, Miller et al. 1997). Therefore, the availability of areas with sufficient food supply during this period (e.g., with high densities of Orthoptera, the main food of Lesser Kestrel; Franco and Andrada 1977, Tejero 1982, pers. obs.) could be important. In our study area high densities of grasshoppers occur 
primarily during summer, and this resource is used by the post-breeding Lesser Kestrel population ( $P$. Olea and $A$. de Frutos unpubl. data), suggesting a role for this area as a premigratory feeding and staging area.

The ca. 1000 Lesser Kestrels counted in our roosts and the ca. 3000 birds found by Ursúa and Tella (2001) in two roosts in the northern Spain, may indicate that a significant fraction of the Spanish Lesser Kestrel population (12000 breeding pairs, BirdLife International 2002) gathered in only four roost sites in this post-fledging period, suggesting the importance of these sites for conservation (Ursúa and Tella 2001). Therefore, we suggest that further studies are required to identify other areas and roosts used by the Lesser Kestrel during post-fledging period. Also, the potential role that these areas could be playing in the ecology and conservation of Lesser Kestrel populations needs to be examined.

\section{Acknowledgments}

We are grateful to Jesús Fernández, Rafael González, Olga Mora, Cristina Trigal, María del Carmen Cordero, Soledad, Irene Marcos, Rodolfo Pozuelo, Tania Velasco, Enrique Osorio and Francisco J. Purroy for their help during the fieldwork. We thank Álvaro de La Puente, Jesús Fernández, Rafael González, who loaned us their telescopes. Vittorio Baglione and two anonymous referees provided valuable suggestions on the manuscript. Juan José Prat improved the English. This research was partially supported by Monteleón-Caja España Foundation. A. de Frutos was financed by a predoctoral fellowship from the University of León.

\section{References}

Anders, A.D., Faaborg, J. \& Thompson, F.R. 1998. Postfledging dispersal, habitat use, and home-range size of juvenile Wood Thrushes. Auk 115, 349-358.

Aparicio, J.M. 1990. Actividad, selección del método de caza y balance energético diario de Falco naumanni durante el periodo premigratorio. Ardeola 37, 163-178.

Beauchamp, G. 1999. The evolution of communal roosting in birds: origin and secondary losses. Behavioral Ecology 10, 675-687.

Bernis, F. 1980. La migración de las aves en el estrecho de Gibraltar : época 
posnuncial. Volumen I. Aves planeadoras. Cátedra de Zoología de Vertebrados. Universidad Complutense, Madrid.

BirdLife International 2002. España incumple el plan de acción del cernícalo primilla. Garcilla 109, 33-35.

Blanco, G., Fargallo, J.A. \& Cuevas, J.A. 1993. Seasonal variations in numbers and levels of activity in a communal roost of Choughs Pyrrhocorax pyrrhocorax in a central Spain. . Avocetta 17, 41-44.

Blanco, G. \& Tella, J.L. 1999. Temporal, spatial and social segregation of redbilled choughs between two types of communal roost: a role for mating and territory acquisition. Animal Behaviour 57, 1219-1227.

Bustamante, J. \& Negro, J.J. 1994. The postfledging dependence period of the Lesser Kestrel (Falco naumanni) in Southwestern Spain. Journal of Raptor Research 28, 158-163.

Cramp, S. \& Simmons, K.E.L. 1980. The Birds of the Western Paleartic. Vol II. Oxford University Press, Oxford.

Donázar, J.A., Ceballos, O. \& Tella, J.L. 1996. Communal roosts of Egyptian Vulture (Neophron percnopterus): dynamics and implications for the species conservation, In Biología y Conservación de las Rapaces Mediterráneas. eds J. Muntaner, J. Mayol, pp. 189-201. SEO/BIRDLIFE (Monografías $\mathrm{n}^{\circ} 4$ ), Palma de Mallorca.

Donázar, J.A., Negro, J.J. \& Hiraldo, F. 1993. Foraging habitat selection, land-use changes and population decline in the lesser kestrel Falco naumanni. Journal of Applied Ecology 30, 515-522.

Franco, A. \& Andrada, J.A. 1977. Alimentación y selección de presa en Falco naumanni. Ardeola 23, 137-187.

García, J. 2000. Dispersión premigratoria del Cernícalo Primilla Falco naumanni en España. Ardeola 47, 197-202.

Hiraldo, F., Negro, J.J., Donázar, J.A. \& Gaona, P. 1996. A demographic model for a population of the endangered lesser kestrel in southern Spain. Journal of Applied Ecology 33, 1085-1093.

Jubete, F. 1997. Atlas de las aves nidificantes de la provincia de Palencia (19871995). Asociación de Naturalistas Palentinos, Palencia.

Kopij, G. 2002. Food of the Lesser Kestrel (Falco naumanni) in its winter quarters in South Africa. Journal of Raptor Research 36, 148-152.

Korpimäki, E. \& Lagerström, M. 1988. Survival and natal dispersal of fledglings of Tengmalm's Owl in relation to fluctuating food conditions and hatching date. Journal of Animal Ecology 57, 433-441.

Llamas, O., Lucio, A. \& Purroy, F.J. 1987. Comunidades de Falconiformes en la llanura cerealista del SE de la provincia de León, In I Congreso Internacional de Aves Esteparias. Junta de Castilla y León, León.

Miller, G.S., Small, R.J. \& Meslow, E.C. 1997. Habitat selection by spotted owls during natal dispersal in western Oregon. Journal of Wildlife Management $61,140-150$. 
Morton, M.L. 1992. Effects of sex and birth date on premigration biology, migration schedules, return rates and natal dispersal in the Mountain White-crowned Sparrow. Condor 94, 117-133.

Negro, J.J., de la Riva, M. \& Bustamante, J. 1991. Patterns of winter distribution and abundance of Lesser Kestrel (Falco naumanni) in Spain. Journal of Raptor Research 25, 30-35.

Negro, J.J., Donázar, J.A. \& Hiraldo, F. 1992. Copulatory behaviour in a colony of Lesser Kestrels sperm competition and mixed reproductive strategies. Animal Behaviour 43, 921-930.

Newton, I. 1979. Population ecology of raptors. T. \& A.D. Poyser, London.

Olea, P.P. 2001a. Postfledging dispersal in the endangered Lesser Kestrel Falco naumanni. Bird Study 48, 110-115.

Olea, P.P. 2001b. Sobre la dispersión premigratoria del Cernícalo Primilla Falco naumanni en España. Ardeola 48, 237-241.

Palumbo, G. 1997. II grillaio. Altrimedia Edizione, Matera, Italy.

Román, J. 1998. Cernícalo Primilla. Noticiario ornitológico. Ardeola 45, 121.

Siegfried, W.R. \& Skead, D.M. 1971. Status of the Lesser Kestrel in South Africa. Ostrich 42, 1-4.

Steenhof, K., Kochert, M.N. \& Moritsch, M.Q. 1984. Dispersal and migration of southwestern Idaho raptors. Journal of Field Ornithology 55, 357-368.

Tejero, E., Soler, M., Camacho, I. \& Ávila, J.M. 1982. Contribución al conocimiento del régimen alimenticio del Cernícalo Primilla (Falco naumanni Fleish 1758). Boletín de la Estación Central de Ecología 22, 7782.

Tella, J.L., Forero, M.G., Donázar, J.A., Negro, J.J. \& Hiraldo, F. 1997. Nonadaptive adoptions of nestlings in the colonial lesser kestrel: proximate causes and fitness consequences. Behavioral Ecology and Sociobiology 40, 253-260.

Tella, J.L., Forero, M.G., Gajón, Á., Hiraldo, F. \& Donázar, J.A. 1996a. Absence of blood-parasitization effects on lesser kestrel fitness. Auk 113, 253-256.

Tella, J.L., Hiraldo, F., Donázar, J.A. \& Negro, J.J. 1996b. Costs and benefits of urban nesting in the Lesser Kestrel, In Raptors in Human Landscape. eds D.M. Bird, D. Varland, J.J. Negro. Academy Press, London, U.K.

Ursúa, E. \& Tella, J.L. 2001. Unusual large communal roosts of Lesser Kestrel in two electric substations of Northern Spain: implications for the conservation of Spanish population, In Abstracts of the $4^{\text {th }}$ Eurasian Congress on Raptors. eds J. Bustamante, G. Crema, E. Casado, J. Seoane, C. Alonso, C. Rodríguez, M. de Lucas, G. Janss, p. 188. Estación Biológica de Doñana and Raptor Research Foundation, Sevilla, Spain. 


\section{Capítulo 2.1}

\section{Análisis y modelado de la distribución}

espacial de la abundancia del Cernícalo Primilla durante el verano: el papel de la autocorrelación espacial

Analyzing and modelling spatial distribution of summering lesser kestrel: The role of spatial autocorrelation. De Frutos, A., Olea, P.P. \& Vera, R. 2007. Ecological Modelling 200, 33-44. 


\section{Resumen}

Los modelos que analizan la distribución espacial de las especies pueden conducir a conclusiones ecológicas erróneas si no tienen en cuenta la autocorrelación espacial (AE) y la multicolinealidad. En el presente estudio se han considerado ambos problemas estadísticos a la hora de examinar y modelar el patrón espacial de la abundancia del amenazado Cernícalo Primilla (Falco naumanni). El estudio se realizó durante el verano en un área de 38.400 ha situada al noroeste de España donde se producen grandes concentraciones premigratorias de cernícalos primillas. El patrón espacial se examinó mediante el correlograma de Moran y se incluyeron las coordenadas geográficas y autocovariables (las cuales tenían en cuenta la $A E$ ) en modelos lineares generalizados (GLM) y de partición jeráquica (HP). Los modelos HP permiten controlar la multicolinealidad. El área de estudio se dividió en 24 cuadrículas contiguas de $4 \times 4 \mathrm{~km}$. Se efectuaron 2-3 visitas por cuadrícula para contabilizar los primillas (variable respuesta). Se midieron variables ambientales de baja resolución a tres extensiones espaciales usando sistemas de información geográfica. El correlograma de Moran mostró que la abundancia media de Cernícalo Primilla por cuadrícula estuvo espacialmente autocorrelada hasta 4-8 $\mathrm{km}$. Los resultados de ambos análisis GLM y HP fueron compatibles. Los modelos GLM explicaron el $80.0 \%$ de la variación de la abundancia de primillas y fueron idénticos en las tres extensiones espaciales. Esta abundancia no fue explicada por las variables ambientales, pero estuvo negativamente relacionada con las distancias al dormidero más cercano y a la colonia de cría con más de 10 parejas. La inclusión de la autocovariable en los modelos mejoró su poder explicativo (de 74.5 a $80.0 \%$ ) y sus residuales, que dejaron de estar espacialmente autocorrelados, cumpliendo por tanto la premisa de independencia en los errores. Los resultados sugieren que la distribución espacial de los cernícalos primillas en verano está determinada, al menos en parte, por factores endógenos, como la atracción conespecífica. Sin embargo resulta necesario considerar factores exógenos, como variables de escala fina (por ejemplo, tipo de cultivo o disponibilidad de alimento), en las relaciones Cernícalo Primilla-hábitat. 


\section{Abstract}

In modelling spatial distribution of species, ignoring spatial autocorrelation (SA) and multicollinearity may lead to false ecological conclusions. Here we take into account both issues for examining and modelling the spatial pattern of abundance of the globally threatened lesser kestrel (Falco naumanni) during summer in a 38400-ha area of northwestern Spain where large premigratory aggregations of the species occur. Spatial pattern was examined using Moran's correlogram, and models were built including geographical coordinates and autocovariate terms (which account for SA) in generalized linear models (GLM) and hierarchical partitioning (HP) models. HP models allow to alleviate multicollinearity. A grid-based approach was used by dividing the study area in 24 contiguous $4 \times 4-\mathrm{km}$ squares where birds were counted in 2-3 visits per square (response variable). Environmental coarse-grained variables were extracted from a Geographic Information System (GIS) at three spatial extents. Moran's correlogram showed that lesser kestrel mean abundance per square was spatially autocorrelated up to 4-8 km. The results from both GLM and HP analyses were roughly compatible. The GLM models explained $80.0 \%$ of the variation in kestrel abundance and were the same at the three spatial extents. Lesser Kestrel abundance was not significantly explained by landscape variables, but was negatively related to both the distance to the nearest communal roost and distance to the nearest breeding colony with more of 10 breeding pairs of lesser kestrel. An autocovariate term added later in the GLM models improved both their explanatory power (from 74.5 to $80.0 \%$ ) and model residuals, which were not longer spatially autocorrelated, fulfilling thus the statistical assumption of independent errors. Findings suggest that the spatial distribution of abundance of summering lesser kestrel is, at least, partially driven by endogenous causes, such as conspecific attraction. Exogenous causes such as finer-scale variables (e.g. type of crops and food available) are yet likely needed for lesser kestrel-environment relationships. 
Capítulo 2.1

Keywords: Environment-species relationships, Lesser kestrel, Falco naumanni, Generalized linear models, Hierarchical partitioning, Spatial autocorrelation, Moran's I, Geographic Information System 


\section{Introduction}

Modelling environment-species relationships is one of the main goals in ecological research (Rushton et al., 2004). Studies modelling the spatial distributions of the species (e.g. Bustamante, 1997; Suárez-Seoane et al., 2002; Gibson et al., 2004a; Franco and Sutherland, 2004) have rapidly increased in recent years with the development of geographical information system (GIS) software and new powerful statistical techniques. GIS tools allow to use large digital cartographic databases and to extract easily potential predictor variables. Powerful statistical techniques, such as multiple regression methods (e.g. generalized linear models [GLM] and generalized additive models [GAM]), allow to identify factors explaining the response variable and to develop predictive models (see Guisan and Zimmermann, 2000). Despite their power, troubles of robustness of models developed using multiple regression techniques have been detected in the presence of multicollinearity between the predictor variables (i.e. that independent variables are correlated; see Mac Nally, 2000; Graham, 2003). Multicollinearity is frequently observed in nature and variables explaining better statistically may be retained in the model, while the important ecological variables are eliminated (Graham, 2003). Therefore, ecological studies that used multiple regressions in presence of multicollinearity may have yielded incorrect ecological conclusions whether multicollinearity was ignored. To solve problems due to multicollinearity, some techniques such as residual/sequential regression, principal component regression, structural equation modelling (Graham, 2003), analysis of variance inflation factor (VIF; Quinn and Keough, 2002), and hierarchical partitioning (HP; Mac Nally, 2002) are used. The use of HP is increasing in ecology and conservation as a complementary technique of modelling processes (see Gibson et al., 2004a; Gibson et al., 2004b; Radford and Bennett, 2004; Heikkinen et al., 2004; Heikkinen et al., 2005), as it allows to identify the independent and shared contributions of explanatory variables to a response, while alleviating multicollinearity (Mac Nally, 2002).

Spatial autocorrelation can be other statistical trouble when modelling species distribution and it has been well established in the ecology 
literature (Legendre, 1993; Diniz-Filho et al., 2003; Legendre et al., 2004; Keitt et al., 2004). The classical statistical methods used to analyze environment-species relationships assume the sample values of the response and explanatory variables to be statistically independent. However, the observations are commonly spatially dependent (spatial autocorrelation; Legendre and Legendre, 1998; Keitt et al., 2004), i.e., the values of the variable in neighbouring locations may be more similar or less similar than expected for locations randomly distributed (Legendre and Legendre, 1998). Thus, models that ignore the spatial dependence in ecological data may be inappropriate because they might have overestimated the importance of covariates (e.g., environmental variables; Lichstein et al., 2002; Ferrer-Castán and Vetaas, 2005), and have included variables that have little or no relevance on the response variable (Overmars et al., 2003; Keitt et al., 2004; Betts et al., 2006) creating false ecological conclusions (Legendre and Legendre, 1998). To solve this problem, different statistical methods have been applied to control or incorporate its spatial effects when modelling environment-species relationships (Lichstein et al., 2002; Keitt et al., 2002; Ferrer-Castán and Vetaas, 2005). One of these alternatives is to incorporate spatial terms in the model, such as the geographical coordinate of the sample locations together with their interactions and an autocovariate term, which takes into account for spatial effects of neighboring locations of the response variable (e.g. Augustin et al., 1996; Hubbel et al., 2001; Seoane et al., 2003; Heikkinen et al., 2005).

On the other hand, the spatial autocorrelation can provide us information on spatial structure of the variables by using geostatistical methods, such as the commonly used Moran's Index (I; Legendre and Legendre, 1998). This index describes and quantifies the similarity among locations as a function of distance (Legendre and Legendre, 1998) allowing to explore the distance (lag) at which the values of a given variable are spatially autocorrelated by taking into account the spatial location of the data (e.g. Cushman and McGarigal, 2003).

In the modelling processes of species distribution, Gibson et al. (2004a) suggested to develop and to combine models obtained at two spatial levels (landscape and site levels). In the first level, a spatially explicit model is developed using predictor landscape variables extracted from a GIS, while in the second level models are based on finer-scale habitat variables measured on-ground, which are difficult to obtain due to 
the time and cost to measure them (see Austin, 2002). Because landscape variables are also likely to be indirectly related with causal variables, models developed at landscape level are most likely to be used for conservation planning (Gibson et al., 2004a).

In this paper we examined the spatial pattern of lesser kestrel (Falco naumanni) abundance and modelled its distribution using environmental factors measured at landscape level. Our study species is a small falcon breeding in the Palaearctic and wintering mainly in Africa (Siegfried and Skead, 1971; Cramp and Simmons, 1980). This species is considered to be a globally threatened species listed as Vulnerable (BirdLife International, 2004). Recent researches have showed that large aggregations of lesser kestrels occur during summer in several Spanish areas where population size attain to be several orders of magnitude larger than breeding populations, suggesting that part of these postbreeding populations coming from other areas (Ursúa and Tella, 2000; Olea et al., 2004). This gregariousness likely lead to kestrel observations to be spatially autocorrelated. The areas occupied during summer by kestrels at least during 2-2.5 months have been suggested to be regular premigratory areas and may be playing an important role in the ecology and conservation of lesser kestrel populations (Olea et al., 2004). However, no works on environmental-kestrel associations have been carried out at these premigratory areas during summer.

Here we 1) described and analyzed spatial pattern of lesser kestrel abundance in a Spanish farmland by using a spatial autocorrelation analysis (Moran's I) and 2) modelled its abundance as a function of landscape variables extracted from GIS at different spatial extents by using two statistical techniques (GLM and HP) taking into account the spatial location of the data.

\section{Methods}

\section{Study area}

Our study was conducted in a 38400 ha area in the province of León, northwestern Spain (centred at $5^{\circ} 15^{\prime} \mathrm{W} 42^{\circ} 21^{\prime} \mathrm{N}$; with $11,7{ }^{\circ} \mathrm{C}$ annual average temperature and $486 \mathrm{~mm}$ precipitation; see details in Olea et al., 2004; Fig. 1a). The landscape is more or less flat and open, with little 
amount of trees. The area is broken up by a number of small seasonal streams flowing in a north-south direction. The dominant habitat was extensive farmland, in rotation every other year (Fig. 1b). Dry cereals and ploughed fields constituted the main crops. Semi-natural grassland and mosaics of poplar groves are mainly found in the river beds. Deciduousmixed forests are scarce and scattered. When we carried out the study, almost all the cereal cultures was harvested, remaining as stubbles and being exploited by a low grazing intensity. Ploughed fields were not sown yet. In 2002, 23 breeding pairs of lesser kestrel were documented in the study area. During summer (July, August and September) this area holds yet a large post-breeding lesser kestrel population (close to 1000 individuals; Olea et al., 2004) which gathers in communal roosts at night and disperse from these roots daily to forage (unpublished data).

The area was divided into 24 contiguous UTM grid 4x4-km $\left(16 \mathrm{~km}^{2}\right)$ squares (Fig. 1b). Spatial grid system approach has been recently suggested to study bird-landscape relationships (Luoto et al., 2004; Virkkala et al., 2004) instead of using scattered study plots. The spatial grid system would allow taking into account the whole range of variation in a landscape.

\section{Bird surveys}

Surveys were carried out in summer of 2002 when lesser kestrel abundance in the area peaked (i.e., during the second fortnight in August and first fortnight in September; see Olea et. al., 2004). We counted birds during two or three visits ( $\mathrm{n}=68$ surveys) in each $16-\mathrm{km}^{2}$ square (first visit: 11 Aug; second visit: 16 Aug; third: 07 Sept). The potential effect of effort on lesser kestrel abundance was taken into account in the analysis (Table 1). To reduce bias by potential movement of kestrels among squares, all the $2416-\mathrm{km}^{2}$ squares were censused in the same day. In each visit, a different approx. 5-km lineal route was designed and covered in car at a low speed (approx. $20 \mathrm{~km} / \mathrm{h}$ ) for censusing kestrels. Censuses by car have been considered as a reliable method to count raptors at least in open landscape (Viñuela, 1997). Windy and rainy conditions were avoided for censusing. We count lesser kestrels localized within a strip $250 \mathrm{~m}$ wide in each side of the itinerary. To avoid circadian rhythms of activity, kestrels were surveyed during all day (Tella et al., 1998) and previous researches showed that kestrels were active throughout the day (see Donázar, 1993; Parr et al., 1997; Tella et al., 1998; Vlachos, 2003). To 
avoid counting lesser kestrel associated with roosting, we did not census during 2 hours after sunrise and 2 hours before sunset (see Olea et al., 2004). To identify kestrels, we used binoculars and spotting scope. We used the index of relative density (IRD, no. of lesser kestrels in $1 \mathrm{~km}$ of driven transect; Viñuela, 1997) for each grid and each visit. Then, the averages of IRD of the visits performed per square were calculated for each grid.

(a)


(b)
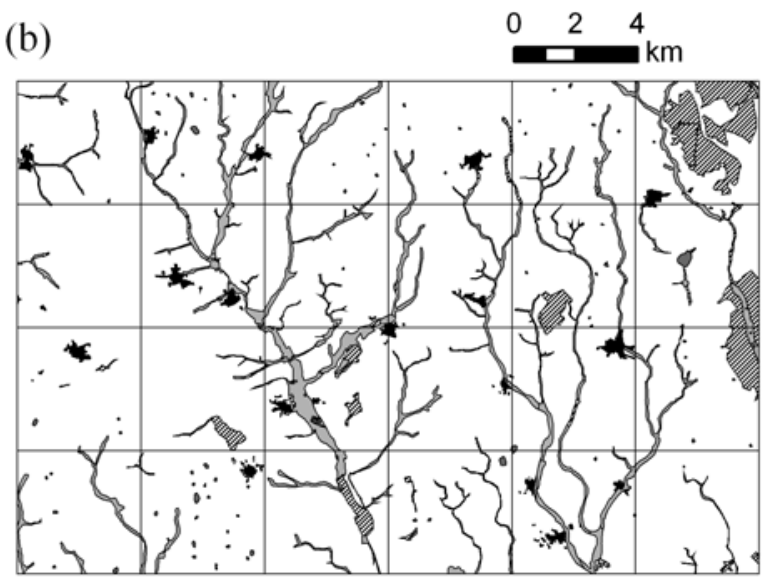

Figure 1. (a) Location of the study area. (b) Distribution of land-use covers within the study area, split into 24 contiguous UTM grid $4 \times 4-\mathrm{km}\left(16 \mathrm{~km}^{2}\right)$ squares.

\section{Environmental data}

Because we aim to look at the spatial extent at which landscape variables could potentially to influence the distribution of kestrel abundance across the study area, habitat predictor variables were measured at three spatial extents: 1) considering the whole $16-\mathrm{km}^{2}$ square (hereafter, landscape extent), 2) considering the area included within 
strips $500-\mathrm{m}$ wide at each side of the routes for censusing kestrels (hereafter, patch extent) and 3) considering the area included within strips 250-m wide (hereafter, plot extent). The cover area by car surveys for censusing kestrels relative to the $16-\mathrm{km}^{2}$ square was on average of $64.3 \%$ (SD: 7.3 ) and $37.4 \%$ (SD: 5.4) for the spatial extent of $500 \mathrm{~m}$ and $250 \mathrm{~m}$ wide, respectively.

Habitat variables associated with each extent in each $16-\mathrm{km}^{2}$ square were obtained with a GIS software, using ARCGIS 8.0 (Environmental Systems Research Institute Inc.). Four variables of broad-scale habitat cover (see Table 1): farmland (FARML), grassland (GRASSL), woodland (FOREST) and build-up areas (BUILD-UP) were estimated as the surface relative to the total area of each extent in each square from a digital landuse layer obtained from georeferenced aerial photographs $(0.7-\mathrm{m}$ pixel resolution). Based on habitat cover variables, two landscape structure variables were calculated, namely habitat edge density (EDGE; total edge length of all habitat patches per $\mathrm{km}^{2}$, see Table 1) and landscape heterogeneity (HETER; habitat diversity using Shannon's diversity index; Heikkinen et al., 2004, see Table 1). Kestrels may select perches as lookout posts (Aparicio, 1990; personal observations) and to be also easier detectable when perching than as posed in the ground, so other explicatory variable, such as total length of electrical wires (WIRE, see Table 1), was considered. It was measured from a digital cartographic map, and this information was corroborated with field observations.

Since distribution of both breeding colonies and communal roosts of lesser kestrel may potentially influence lesser kestrel abundance (see Olea et al., 2004), breeding colonies and communal roosts of kestrels within and outside from the study area were mapped. Based on this information, four raster layers, "distance to the nearest roost" (DROOST), "distance to the nearest colony" (DCOLONY), "distance to the nearest colony with more than 5 breeding pairs" (DCOLONY5), and "distance to the nearest colony with more than 10 breeding pairs" (DCOLONY10) from the centre of each grid square were generated (see Table 1). In the study area and its surroundings, the biggest lesser kestrel colony had 15 breeding pairs. 


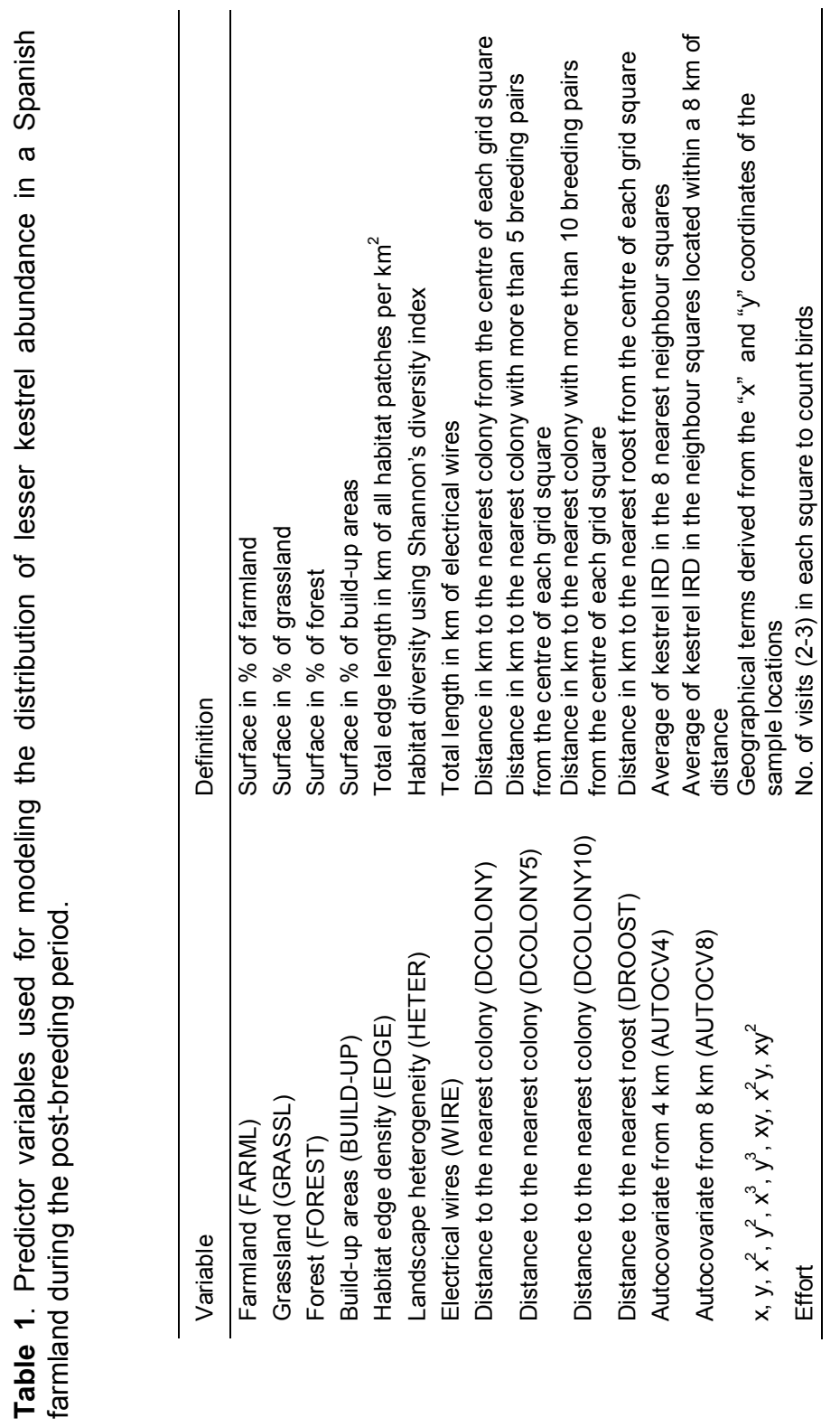

Statistical analysis

To evaluate the spatial pattern of kestrel abundance, we examine the spatial autocorrelation by using the Moran's index $(I)$ as a function of spatial distance (see Legendre and Legendre, 1998; Sawada, 1999). This 
index indicates the degree of similarity/dissimilarity between the values of the variable considered and ranges approximately from +1 (aggregated distribution) to -1 (regular distribution). Values of $I$ are approximately equal to zero $\left(-1 /\right.$ [ $n^{\circ}$ squares-1]) when arrangement is random. We calculated values of $I$ for the kestrel abundance for five intersample lag distances, each of 4-km extent (i.e., equivalent to a square in our study). Correlograms plot the Moran's I coefficients against distances between localities (Legendre and Fortin, 1989). Absence of spatial autocorrelation can be identified when the line is close to zero (i.e., sampling data are spatially independent). To test the significance of these Moran's coefficients for each lag distance, 9999 Monte Carlo permutations of the original data were performed and its $P$-values were calculated (Sawada, 1999; Heikkinen et al., 2004). The Moran's correlogram as a whole is considered significant if at least one of its coefficients is significant at the probability level after progressive Bonferroni correction (here $P \leq 0.01$ ). Moran's I statistics and correlogram were computed using the program ROOKCASE (Sawada, 1999).

Lesser kestrel abundance was log-transformed $(\operatorname{In}[x+0.5])$ to reach normal distribution being thus modelled using GLM with a Gaussian error and a function identity link in the program S-PLUS 2000 (MathSoft, 2000). Transformations of the independent variables (square-root, arcsin, logarithm and potential, depending of the case) were performed for improving the linearity of relationships between predictor and response variables. Out of the three highly intercorrelated variables detailing with distance to colony $\left(r_{s}>0.7\right.$; Table 1$)$, we only retained for analysing the one with the highest explained variation of the lesser kestrel abundance (DCOLONY10).. To avoid over-fitting and resulting biases in the multiple regression, Crawley (2002) recommends to include no more than $n / 3$ variables at any one time in the initial model, where $n$ is the total sample size. Accordingly, we only introduced 8 variables in any one time in our 24-cases model. Variables were tested for non-linear relationships (i.e., polynomial terms, up to third degree) with the response variable. Quadratic and cubic terms were fitted along with the linear effects. For each set of 8 variables entered in the model, an automatic combination of forward stepwise selection and backward stepwise elimination procedures (procedure step) was used to select the best (in terms of AIC) model. The resulting model automatically obtained was then checked for significance of all the variables included by looking whether $P \leq 0.05$ based in F- tests. 
As no more than 8 variables were simultaneously tested, significant terms were retained in the model and tested again with the rest of variables nontested with the significant terms (see Crawley 2002 for a similar procedure with many explanatory variables in multiple regression).

As spatial autocorrelation was found in our data set (both in the response variable and in the residuals from the models; see below), several spatial variables were included in the modelling approach to control their spatial effects (see Lichstein et al., 2002; Seoane et al., 2003; Virkkala, et al., 2004; Betts et al., 2006). We added these variables in the final regression model, after all the important environmental variables were selected. On one hand, the geographical coordinates ( $x$ and $y$ ) and their linear and non-linear interactions $\left(x^{2}, y^{2}, x^{3}, y^{3}, x y, x^{2} y, x y^{2}\right)$ for each square were calculated. According to Legendre and Legendre (1998), we previously centered $x$ and $y$ on their respective means and standardized them to unit variance. Each one of these terms was considered as a spatial variable. We develop also a spatial autocovariate term (see Augustin et al., 1996; Keitt et al., 2004), which allows us to measure the spatial autocorrelation in the response variable (lesser kestrel abundance in our case). As spatial autocorrelation was no longer significant between 4 and $8 \mathrm{~km}$ (see later), we developed two autocovariates (AUTOCV4 and AUTOCV8; see table 1). AUTOCV4 was obtained as the average of kestrel IRD in the 8 nearest neighbouring squares of each study square (i.e., located at $4 \mathrm{~km}$ ), while AUTOCV8 was obtained from values of the squares within a distance of $8 \mathrm{~km}$. For the squares at the edges of the study area, the average was calculated from available neighbouring squares. We checked the assumption of independent errors by examining Moran's correlograms of residuals of the models with and without spatial variables.

Because generalized linear models can be seriously affected by (multi)collinearity between the explanatory variables (i.e., correlation among them; see Graham, 2003), we use HP procedure. HP reduces collinearity problems by determining the independent contribution that each explanatory variable has on the response variable and separates it from the conjoint contribution, resulting from correlation with other variables. The method of fitting the model to data was by least squares (i.e., the goodness-of-fit measures were calculated by R-squared; see Walsh and Mac Nally, 2004). 
The variables explaining a significant proportion of independent variance in the response variable was tested by 500 randomizations (see Mac Nally, 2002). HP was performed using the "hiert.part package" version 1.0 (Walsh and Mac Nally, 2004), which was run in the $R$ statistical software ( $R$ version 2.0.1; a programming environment for data analysis and graphics). This HP version allows running models with a maximum number of 12 predictor variables. Yet, due to the loss of robustness of this HP software when entering more than 9 predictor variables (Olea and De Frutos, submitted), we only used 9 variables: the spatial variable, AUTCOV4, plus those 8 out of the 9 linear environmental variables used in the GLM that more individual variation explained of the response variable (Table 4 ).

Because proportions of habitat cover are not completely independent each other (so called unit sum constraint problem; sensu Aesbischer et al., 1993), the four variables of habitat cover were transformed to pairwise log-ratios (see Aesbischer et al., 1993; Virkkala et al., 2004). However, final GLM models remained the same whether the log-ratios ( $P$-value= 0.14-0.92) or the variables non-transformed (see below) were considered. As log-ratios in HP would have not a simple interpretation and also it already control for multicollinearity (McNally, 2002), we did not use the log-ratio transformation for habitat cover variables further (see Heikkinen et al., 2004; Heikkinen et al., 2005).

\section{Results}

\section{General results}

The lesser kestrel mean abundance per square in the study area ranged from 0 to 2.3 per $16-\mathrm{km}^{2}$ grid square $\left(0.83\right.$ kestrels $\mathrm{km}^{-1}$ on average). The spatial distribution of lesser kestrel abundance in the study area is shown in the Figure 2. The mean, standard deviation and range of the explanatory variables at each spatial extent (landscape, patch and plot extents) are shown in Table 2. The dominant habitat cover variable was farmland; on average, it represented $91 \%, 87 \%$ and $83 \%$ of the prospected surface at each spatial extent, respectively. 


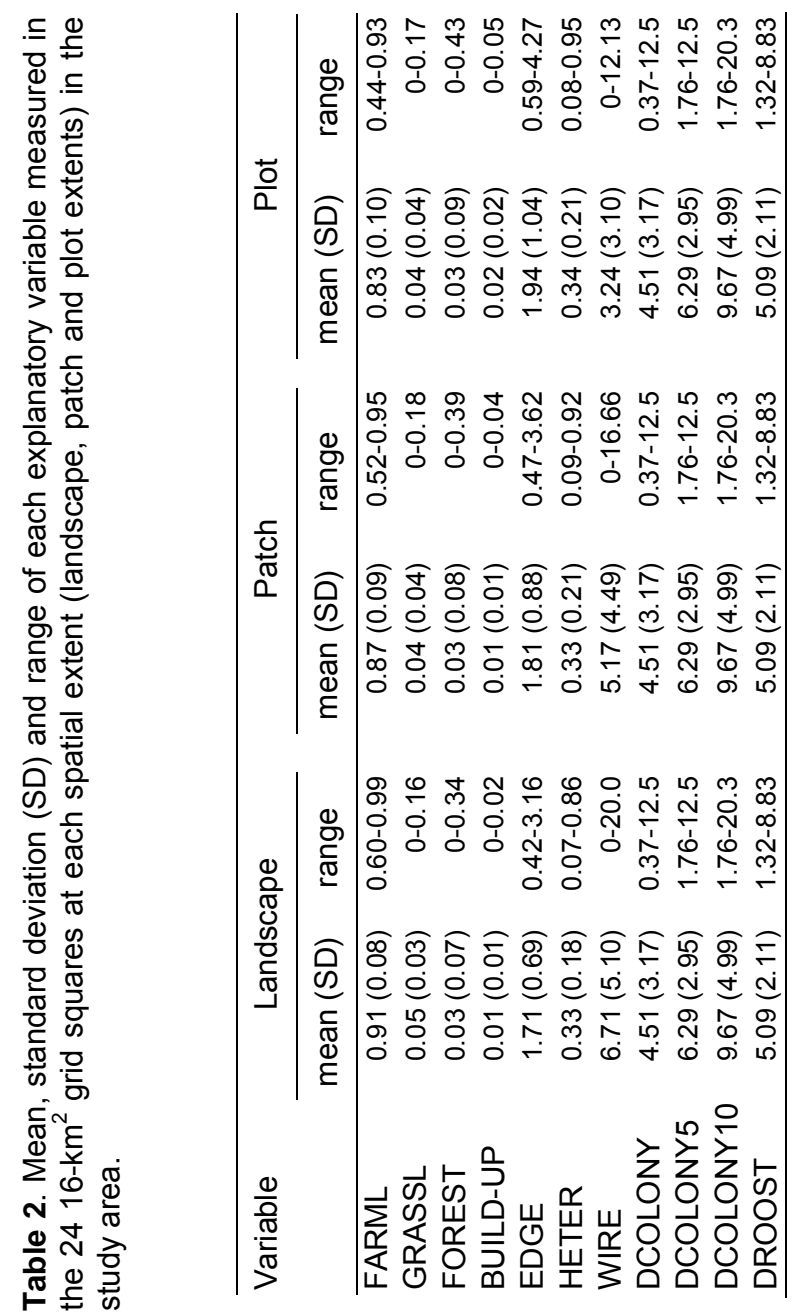

\section{Spatial autocorrelation}

The Moran's correlogram of lesser kestrel abundance as a whole was significant $(P=0.01)$, due to the statistically significant positive autocorrelation of kestrel abundance for the first lag class (i.e., at $4 \mathrm{~km}$; Moran's $I=0.31 ; P=0.01)$, but not for the other distances $(8,12,16$ and $20 \mathrm{~km}$ ). This correlogram showed a monotonic decline in the Moran's I values of spatial autocorrelation for lesser kestrel abundance (Fig. 3). 


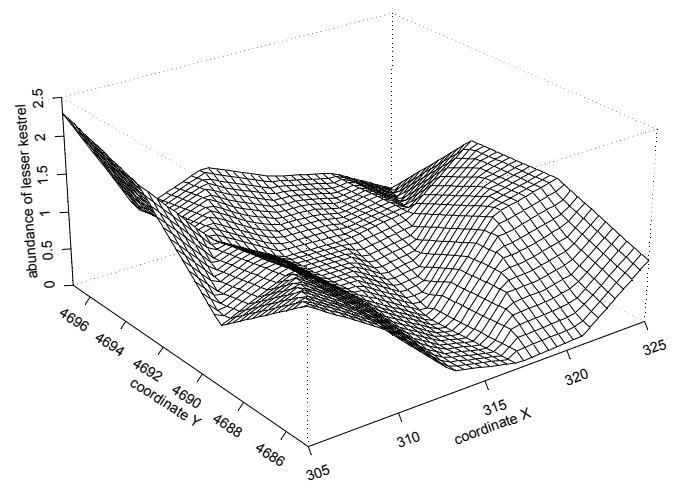

Figure 2. Spatial distribution of lesser kestrel RDI (Relative Density Index) in a 384-km² Spanish farmland during summer of 2002. Coordinate $\mathrm{X}$ : longitude in UTM (in $\mathrm{km}$ ). Coordinate $\mathrm{Y}$ : latitude in UTM (in $\mathrm{km}$ ).

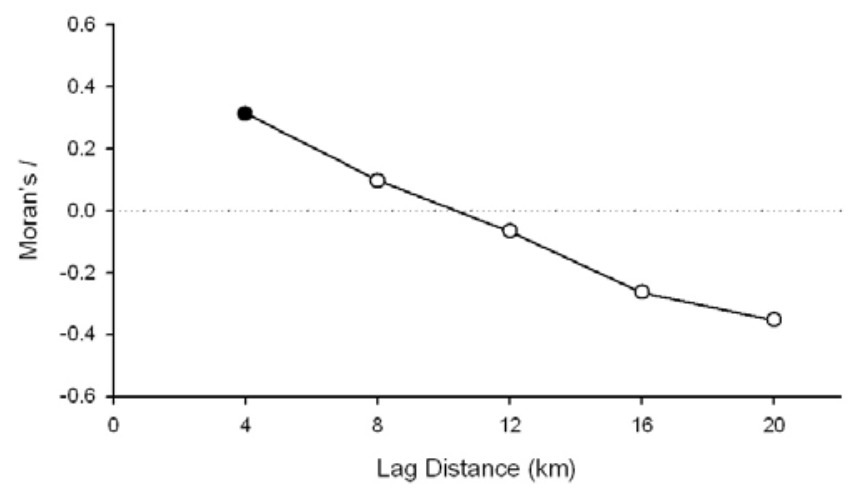

Figure 3. Spatial correlogram of Moran's I for lesser kestrel mean abundance in a 38400-ha Spanish farmland during summer of 2002. The abscissa is lag distance classes and the ordinate Moran's I coefficients, which ranges approximately from +1 (aggregated distribution) to -1 (regular distribution). Black circles represent significant values at the probability level after sequential Bonferroni correction (here $P<0.01$ ), and open circles insignificant values.

\section{Model selection}

The GLM models explaining kestrel abundance were the same at the three spatial extents (landscape, patch and plot extents). From the spatial variables added later, only AUTOCV4 improved this GLM model (from 
74.5 to $80.0 \%$ ). The final model explained $80.0 \%$ of the variation in the kestrel abundance (total deviance change 4.18 out of 5.23; Table 3). Three explanatory variables, AUTOCV4, DROOST, and DCOLONY $10^{3}$ were included significantly in the model (Table 3), explaining 42.2, 14.9 and $30.3 \%$ of the explained by the model, respectively. The coefficients of the variables indicate that the DROOST and DCOLONY $10^{3}$ were negatively associated with kestrel abundance (Fig. 4), while AUTOCV4 was positively associated (Table 3 ). DROOST had a decreasing monotonic relation with kestrel abundance, while DCOLONY $10^{3}$ had a parabolic relation that decreased markedly from approx.10 km (Fig. 4). Residuals from the model before adding spatial variables showed a spatial pattern and were significantly autocorrelated at the third and fifth lag distances (i.e., at 12 and $20 \mathrm{~km}$, respectively; Fig. 5a), while model residuals after controlling for spatial effects did not show a significant spatial pattern (Fig. 5b).

The independent and joint contribution percentages of each predictor variables for kestrel abundance estimated in HP analysis are shown in Figure 6. The four variables with the highest independent contribution percentages were AUTOCV4 $(24.9,25.4,27.7 \%$ at the landscape, patch and plot extents, respectively), DROOST (8.8, 7.5, 9.0\%), FARML (7.8, $12.3,13.0 \%)$ and DCOLONY10 (6.5, 6.3, 6.7\%). However, the AUTOCV4 variable was the only variable with a significant explanatory power for the kestrel abundance at the three spatial extents (landscape, patch, and plot; Table 4). 


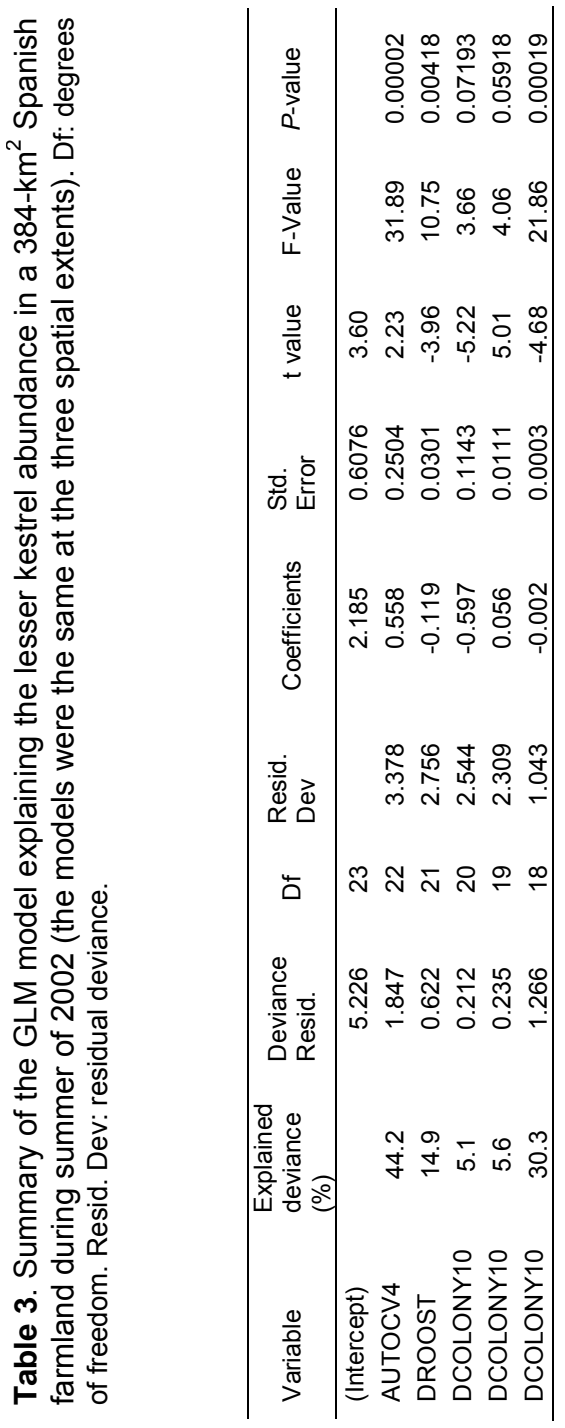


Capítulo 2.1

(a)



(b)

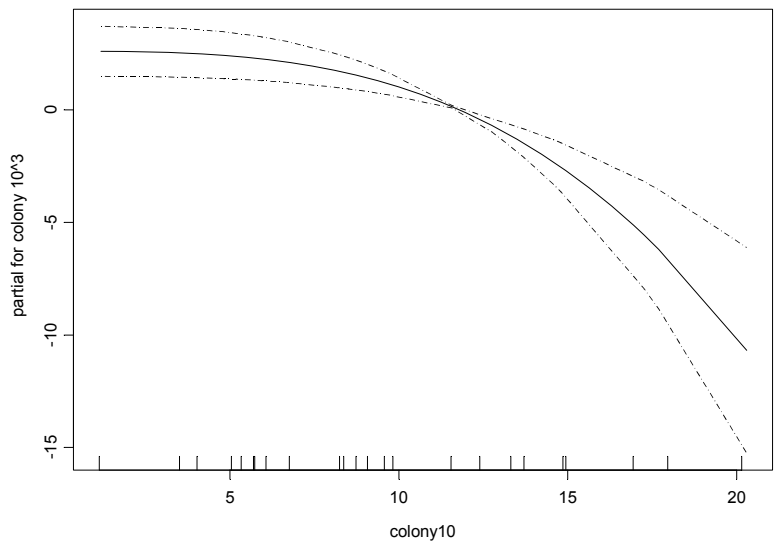

Figure 4. Mean partial effect of (a) distance to the nearest roost of lesser kestrel and (b) distance to the nearest colony with more of 10 breeding pairs on lesser kestrel abundance during the summer of 2002. Broken lines indicate the SE of the mean. The rugplot on the x-axes indicates the density of data points. 
(a)

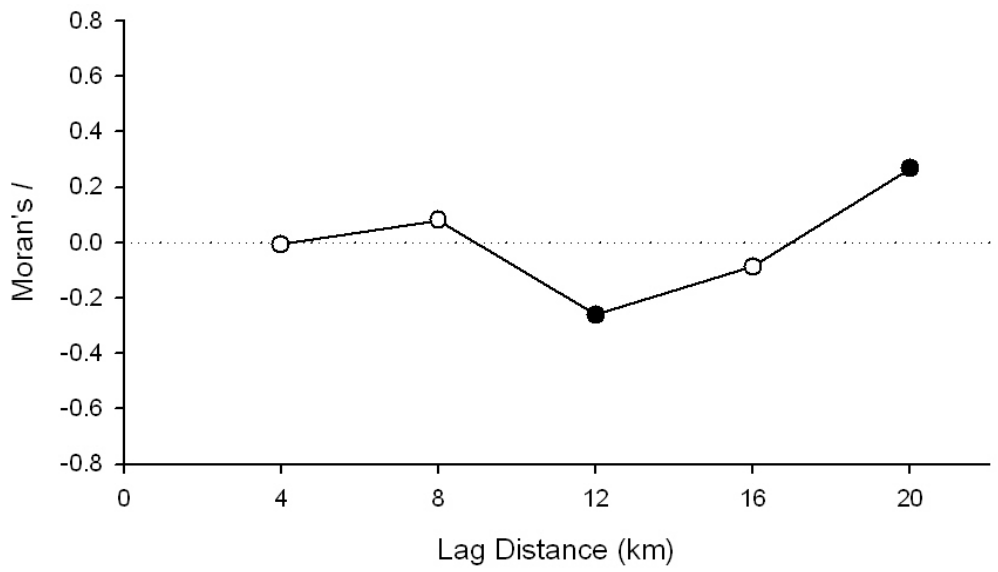

(b)

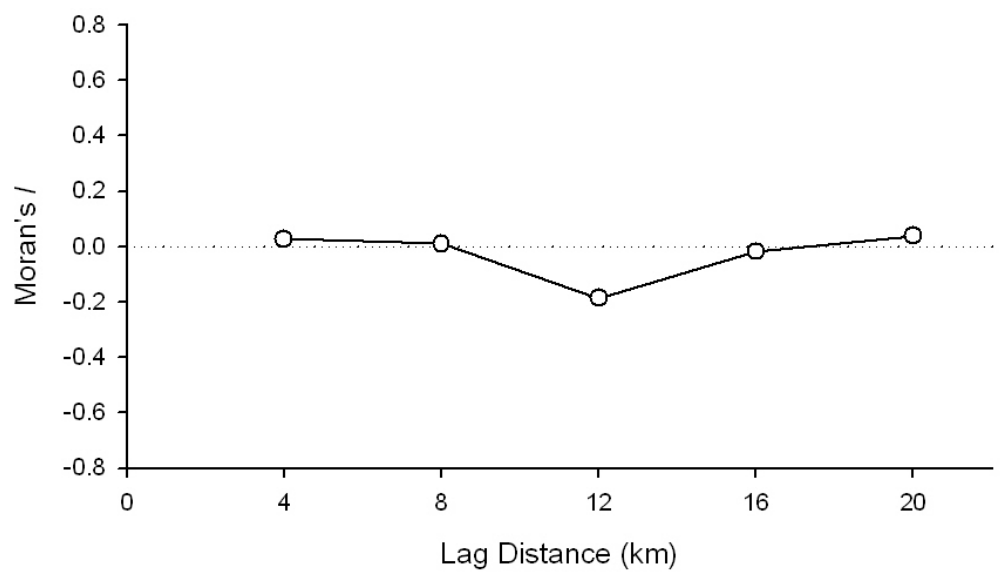

Figure 5. Spatial correlogram of Moran's I for residuals from the GLM models (a) before and (b) after adding autocovariate to explain lesser kestrel abundance in a 384- $\mathrm{km}^{2}$ Spanish farmland during summer of 2002. Black circles represent significant values at the probability level after sequential Bonferroni correction (here $\mathrm{P}<0.01$ ), and open circles insignificant values. 



(a) 


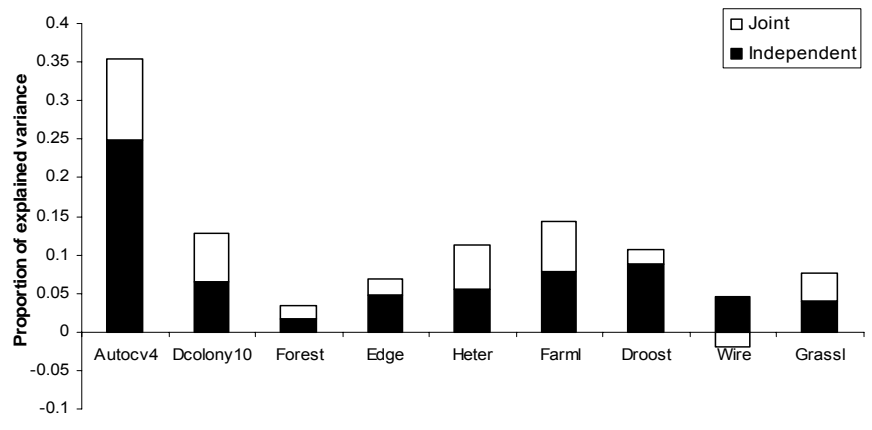

(b)

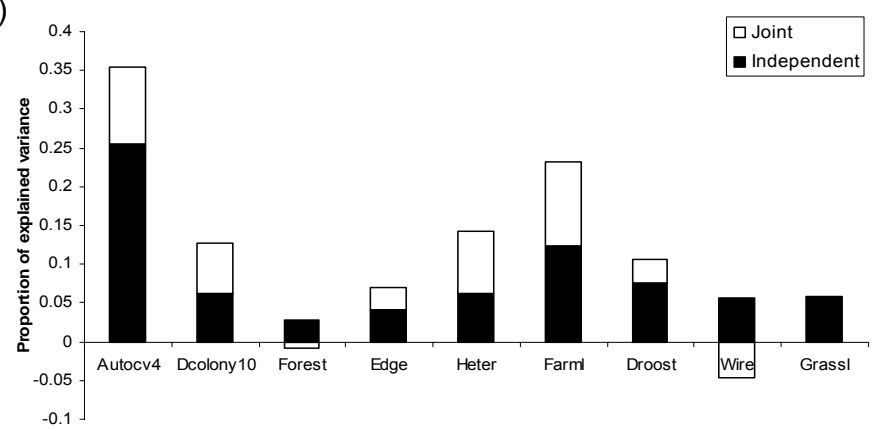

(c)

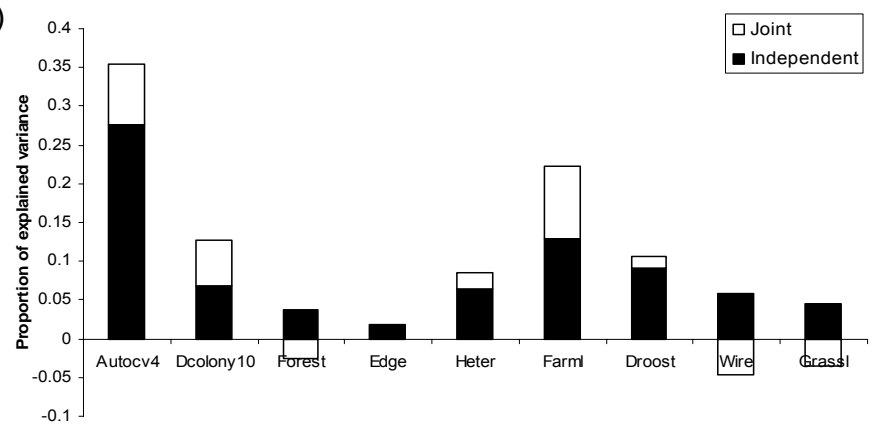

Figure 6. Independent and joint contributions of each explanatory variable for lesser kestrel abundance at each spatial extent considered for the study: (a) whole $16-\mathrm{km}^{2}$ square (namely, landscape extent), (b) area included within strips $500-\mathrm{m}$ wide at each side of the routes for censusing kestrels (patch extent) and (c) area included within strips 250-m wide (plot extent). Note: Negative joint contribution of one variable indicates that the other variables act as suppressor on the particular variable (Chevan and Sutherland, 1991). 


\section{Discussion}

Lesser kestrel mean abundance in the 24 contiguous $16-\mathrm{km}^{2}$ squares was significantly spatially autocorrelated, which was due to a significant spatial autocorrelation in the first distance class (i.e., $4 \mathrm{~km}$ ), as indicated by Moran's correlogram (Fig. 3). This correlogram profile fit to one of the three basic types of profiles found in ecological data (Diniz-Filho et al., 2003), indicating that lesser kestrel abundance would be spatially structured in patches (i.e., the spatial pattern of kestrel abundance was aggregated). If a significant positive autocorrelation is found in the first distance class but not in the second class (as in our case), Diniz-Filho and Telles (2002) indicated that the average patch size in the variable would be between first and second upper limits of the distance classes. Therefore, in our study the average patch diameter in lesser kestrel abundance would be between 4-8 km (first and second distant class, Fig. 3 ), and consequently this diameter would be the minimum distance among observations to obtain values of lesser kestrel abundance spatially independent in our study system (see Diniz-Filho and Telles, 2002; DinizFilho et al., 2003).

Data spatially dependent (as in our case) have been discussed as a statistical problem in the model development (Lichstein et al., 2002; Overmans et al., 2003; Diniz-Filho et al., 2003). When assumption of independence is not fulfilled for spatial dependence, Legendre (1993) suggested to incorporate the spatial structure into modelling approach. When spatial autocorrelation in the response variable is thought to result from endogenous population processes (e.g. the lesser kestrel gregariousness observed in the period studied), an autocovariate term can be added into models (see Augustin et al., 1996; Heikkinen et al., 2005; Betts et al., 2006). After adding autocovariate variable (namely AUTOCV4) in our GLM models, their explanatory power was improved. This improvement is due to the fact that the autocovariate variable takes into account for spatial effects of neighboring locations of the response variable (Hubbel et al., 2001), which in our case were spatially autocorrelated at neighboring squares (i.e., $4 \mathrm{~km}$; see above). Much of the spatial autocorrelation of the response variable (at least at shortest distances) was longer explained by the covariables (DROOST and DCOLONY10; Fig. 4a), as indicated by model residuals being close to zero values for the first and second lags (i.e., at 4 and $8 \mathrm{~km}$, respectively; 
Fig. 4a). However after incorporating AUTOCOV4, residuals from the model improved, as were not longer significantly spatially autocorrelated (Fig. 4b), and thus it was not violated the assumption of independence of errors in the statistical models.

The results of hierarchical partitioning were consistent between the three models at different spatial extents. Autocovariate variable was the only significant variable selected from the set of 9 predictor variables to explain the variance of kestrel abundance. This does not agree in principle with our results of the GLM approach, in which other two variables (DCOLONY10 ${ }^{3}$ and DROOST) together with the AUTOCV4, were selected by GLM models. However, we did not include the cubic term of DCOLONY10 in hierarchical partitioning analysis due to dependency of this technique on monotonic relationships between the response and explanatory variables (Heikkinen et al., 2004; Heikkinen et al., 2005) and none of the linear terms (except AUTOCOV4) without being joined with polynomial terms, explained significantly the variability of kestrel abundance in the GLM models. Therefore results from GLM and HP seem to be roughly compatible.

The final GLM models explaining lesser kestrel abundance were the same at the three spatial extents (landscape, patch and plot extents). The negative association between kestrel abundance and DROOST at all spatial extents can be owed to the fact that kestrels use these sites for roosting each night (see Olea et al., 2004, unpublished data), suggesting that kestrels tend to foraging around roost sites and thus roosts might structure distribution of kestrels in the studied period. This agrees with Hamilton's refuging theory, which states that animals would use a roost as a central place within the area of food supply and disperse from this roost daily to forage (Hamilton et al., 1967; Hamilton and Watt, 1970). The negative association between kestrel abundance and DCOLONY10 at all spatial extents might be owed to the fact that part of the lesser kestrel population is formed of the local breeding kestrel population and consequently might forage near their colonies. This fact is supported by both the sightings of several pairs of lesser kestrel breeding up to later August in our study area (unpublished data) and by that found by Bustamante and Negro (1994), who observed post-breeding individuals at the colonies during summer in the southern Spain. The fact that much of the spatial autocorrelation of the lesser kestrel abundance was explained by only covariates related with distance to colony and roost, and that the 
AUTOCV4 substantially improved the models, suggests that the spatial distribution of lesser kestrel found is likely to be resulted from (or to be partially influenced by) endogenous factors in lesser kestrel (social factors, behaviour) such as conspecific attraction (see Augustin et al., 1996; Beauchamp et al., 1997; Keitt et al., 2002, Lichstein et al., 2002). Indeed, lesser kestrel has been showed to use conspecific attraction for selecting breeding colony in both its first and subsequent reproductive times (Serrano et al., 2001; Serrano et al., 2004).

Other variables were no significantly selected by the models (GLMs and hierarchical partitioning). Pribil and Picman (1997) argued that different environmental variables can influence habitat use of birds at different scales. Accordingly, the environmental variables considered in our study might influence on kestrel abundance at a larger or smaller spatial scale than the one considered in our study. Moreover, other three possible causes not mutually excluding might explain why landscape variables were not selected in our analysis: a) these variables had not sufficient variability to explain spatial kestrel abundance (Virkkala et al., 2004), despite the large prospect surface (38400 ha), b) the landscape variables considered in our analysis might be not selected by kestrels during the postfledging period, and c) the possible environmental variables affecting the lesser kestrel abundance were no considered in our study; these environmental variables may be coarse-grained landscape variables (e.g. index of plant productivity) as well as fine-scale variables measured on-ground (i.e. the causal environmental variables such as type of crops; see Legendre, 1993). In many cases, these causal variables are very difficult to know and measure (e.g. food available; see Austin, 2002).

Some recent works have modelled species' distribution without considering spatial autocorrelation in their data (e.g. in bird species: Gibson et al., 2004a; Seoane et al., 2004a; Seoane et al., 2004b; in mammal species: Posillico et al., 2004; Gibson et al., 2004b; Gibson et al., 2004c; in fish species: Pont et al., 2005; in shrub species: Beck et al., 2005). Other works considered spatial autocorrelation by including spatial coordinates (e.g. Bustamante et al., 2004) or an autocovariate term (e.g. Seoane et al., 2003; Sanderson et al., 2005) in the models but without examining later their effectiveness by looking model residuals. Our study suggest that works on modelling of species' distribution would benefit whether the spatial pattern of the response variable as well as of the 
residuals from the obtained models is taken into account, as it would allow to improve the statistical models and the understanding of the species ecology. Also, the combined use of GLM and HP can provide firmer conclusions on species-environment relationships, while alleviating (multi)collinearity. Our approach may be applied in other modelling context where spatial data are used by following the steps in Figure 7. It could be the case of recent studies on habitat selection (Oppel et al., 2004; Anderson et al., 2005), nesting habitat (García-Ripollés et al., 2005), foraging habitat (Franco and Sutherland, 2004); feeding response (Gavashelishvili and McGrady, 2006), damage of forests (Božić et al., 2006), aquatic plant richness (Edvarsen and Økland, 2006), shifts in the vegetation occurrence (Tan and Beklioglu, 2005), or land use change (Aspinall, 2004).

\section{Conclusion}

Our results showed a significant positive spatial autocorrelation in the response variable (lesser kestrel abundance) at distances between 4 and $8 \mathrm{~km}$, i.e. abundance values in one square were likely to be similar to that of its neighbor squares. These findings could be taken into account for future sampling strategies in works based on a spatial grid system, as the minimum distance to obtain spatially independent abundance data in our study should be of between 4 and $8 \mathrm{~km}$. However, sample locations so widely spaced may suppose a logistic problem to obtain a large sample size due to increased travel time. Consequently, a solution to increase sample size minimizing sample time would be to collect samples at shorter distances whether spatial autocorrelation is corrected or controlled during the modelling processes (Lichstein et al., 2002). To know more exactly the distance at which spatial autocorrelation we found actually disappears (i.e., between 4 and $8 \mathrm{~km}$ ), studies at finer scale (e.g. sampling squares distanced at $1 \mathrm{~km}$ intervals) could be examined. 


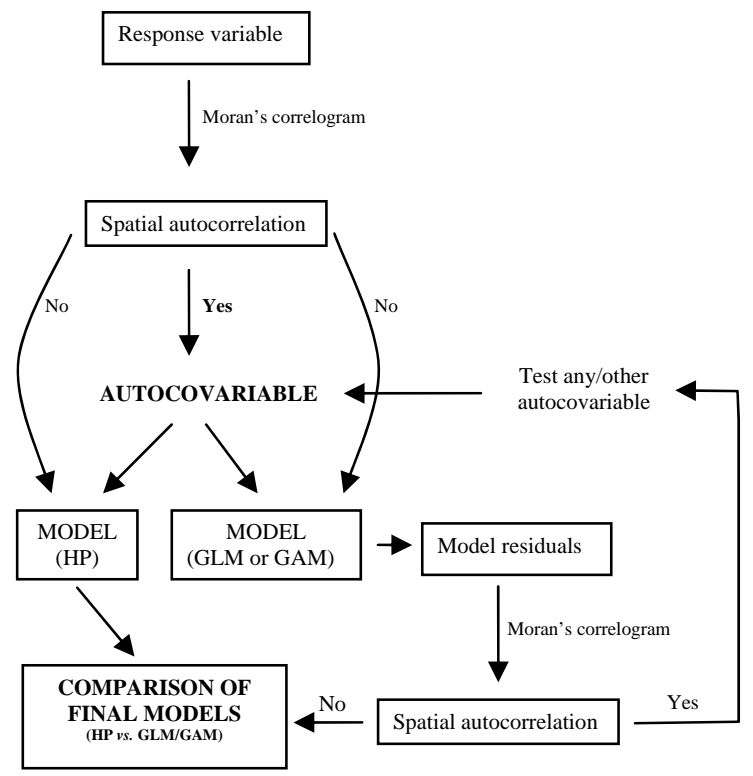

Figure 7. Overview of the steps of our modelling procedure, which may be applied to other modelling context where spatial data are used.

The spatial autocorrelation found should also be taken into account in predictive models to explain lesser kestrel abundance, as it may improve the model power and, from a conservation viewpoint, explanatory variables important for conservation and managing might be misleading whether spatial autocorrelation is not considered (e.g. Overmans et al., 2003).

The summering lesser kestrel abundance was only explained by covariates resulted from kestrel behaviour (roost and colony sites), suggesting that its spatial distribution is likely to be resulted from endogenous factors in lesser kestrel (social organization and conspecific attraction of the species) at least at the scale considered.

Because environmental variables were not selected in our models to explain summering lesser kestrel abundance, models using variables measured on-ground (i.e., models at site level in accordance with Gibson et al., 2004a) need to be generated to improve our understanding of the lesser kestrel-environment associations in this phenological period. Our study suggest that the works on modelling of species-environment 
relationships should take into account the spatial pattern of the response variable as well as of the residuals from the obtained models. This modelling approach would allow to improve the statistical models and the understanding of the species ecology.

\section{Acknowledgments}

We are grateful to Olga Mora, Hugo Robles, Enrique Osorio and Francisco J. Purroy for their help during the fieldwork. The georeferenced aerial photographs were provided by the Junta de Castilla y León. This research was partially supported by Monteleón-Caja España Foundation. A. F. was financed by FPU predoctoral fellowship of the University of León.

\section{References}

Aebischer, N.J., Robertson, P.A. \& Kenward, R.E. 1993. Compositional Analysis of Habitat Use from Animal Radio-Tracking Data. Ecology 74, 1313-1325.

Anderson, D.P., Turner, M.G., Forester, J.D., Zhu, J., Boyce, M.S., Beyer, H. \& Stowell, L. 2005. Scale-dependent summer resource selection by reintroduced elk in Wisconsin, USA. Journal of Wildlife Management 69, 298-310.

Aparicio, J.M. 1990. Actividad, selección del método de caza y balance energético diario de Falco naumanni durante el periodo premigratorio. Ardeola 37, 163-178.

Aspinall, R. 2004. Modelling land use change with generalized linear models - a multi-model analysis of change between 1860 and 2000 in Gallatin Valley, Montana. Journal of Environmental Management 72, 91-103.

Augustin, N.H., Mugglestone, M.A. \& Buckland, S.T. 1996. An autologistic model for the spatial distribution of wildlife. Journal of Applied Ecology 33, 339347.

Austin, M.P. 2002. Spatial prediction of species distribution: an interface between ecological theory and statistical modelling. Ecological Modelling 157, 101118.

Beauchamp, G., Belisle, M. \& Giraldeau, L.A. 1997. Influence of conspecific attraction on the spatial distribution of learning foragers in a patchy habitat. 
Journal of Animal Ecology 66, 671-682.

Beck, P.S.A., Kalmbach, E., Joly, D., Stien, A. \& Nilsen, L. 2005. Modelling local distribution of an Arctic dwarf shrub indicates an important role for remote sensing of snow cover. Remote Sensing of Environment 98, 110-121.

Betts, M.G., Diamond, A.W., Forbes, G.J., Villard, M.A. \& Gunn, J.S. 2006. The importance of spatial autocorrelation, extent and resolution in predicting forest bird occurrence. Ecological Modelling 191, 197-224.

BirdLife International 2004. Falco naumanni, In 2004 IUCN Red List of Threatened Species. http://www, redlist,org Downloaded on 03 May 2005. ed. IUCN.

Božić, M., Antonić, O., Pernar, R., Jelaska, S.D., Križan, J., Čavlović, J. \& Kušan, V. 2006. Modelling the damage status of silver fir trees (Abies alba Mill.) on the basis of geomorphological, climatic and stand factors. Ecological Modelling 194, 202-208.

Bustamante, J. 1997. Predictive models for lesser kestrel Falco naumanni distribution, abundance and extinction in southern Spain. Biological Conservation 80, 153-160.

Bustamante, J. \& Negro, J.J. 1994. The postfledging dependence period of the Lesser Kestrel (Falco naumanni) in Southwestern Spain. Journal of Raptor Research 28, 158-163.

Bustamante, J. \& Seoane, J. 2004. Predicting the distribution of four species of raptors (Aves : Accipitridae) in southern Spain: statistical models work better than existing maps. Journal of Biogeography 31, 295-306.

Chevan, A. \& Sutherland, M. 1991. Hierarchical Partitioning. American Statistician $45,90-96$.

Cramp, S. \& Simmons, K.E.L. 1980. The Birds of the Western Paleartic. Vol II. Oxford University Press, Oxford.

Crawley, M.J. 2002. Statistical computing :an introduction to data analysis using S-Plus. Jonh Wiley \& Sons, England.

Cushman, S.A. \& McGargal, K. 2003. Landscape-level patterns of avian diversity in the Oregon Coast Range. Ecological Monographs 73, 259-281.

Diniz, J.A.F., Bini, L.M. \& Hawkins, B.A. 2003. Spatial autocorrelation and red herrings in geographical ecology. Global Ecology and Biogeography 12, 5364.

Diniz, J.A.F. \& Telles, M.P.D. 2002. Spatial autocorrelation analysis and the identification of operational units for conservation in continuous populations. Conservation Biology 16, 924-935.

Donázar, J.A., Negro, J.J. \& Hiraldo, F. 1993. Foraging habitat selection, land-use changes and population decline in the lesser kestrel Falco naumanni. Journal of Applied Ecology 30, 515-522.

Edvardsen, A. \& Økland, R.H. 2006. Variation in plant species richness in and adjacent to 64 ponds in SE Norwegian agricultural landscapes. Aquatic Botany 85, 79-91. 
Ferrer-Castán, D. \& Vetaas, O.R. 2005. Pteridophyte richness, climate and topography in the Iberian Peninsula: comparing spatial and nonspatial models of richness patterns. Global Ecology and Biogeography 14, 155165.

Franco, A.M.A. \& Sutherland, W.J. 2004. Modelling the foraging habitat selection of lesser kestrels: conservation implications of European Agricultural Policies. Biological Conservation 120, 63-74.

García-Ripollés, C., López-López, P., García-López, F., Aguilar, J.M. \& Verdejo, J. 2005. Modelling nesting habitat preferences of Eurasian Griffon Vulture Gyps fulvus in eastern Iberian Peninsula. Ardeola 52, 287-304.

Gavashelishvili, A. \& McGrady, M.J. 2006. Geographic information system-based modelling of vulture response to carcass appearance in the Caucasus. Journal of Zoology 269, 365-372.

Gibson, L.A., Wilson, B.A. \& Aberton, J.G. 2004c. Landscape characteristics associated with species richness and occurrence of small native mammals inhabiting a coastal heathland: a spatial modelling approach. Biological Conservation 120, 75-89.

Gibson, L.A., Wilson, B.A., Cahill, D.M. \& Hill, J. 2004b. Modelling habitat suitability of the swamp antechinus (Antechinus minimus maritimus) in the coastal heathlands of southern Victoria, Australia. Biological Conservation $117,143-150$.

Gibson, L.A., Wilson, B.A., Cahill, D.M. \& Hill, J. 2004a. Spatial prediction of rufous bristlebird habitat in a coastal heathland: a GIS-based approach. Journal of Applied Ecology 41, 213-223.

Graham, M.H. 2003. Confronting multicollinearity in ecological multiple regression. Ecology 84, 2809-2815.

Guisan, A. \& Zimmermann, N.E. 2000. Predictive habitat distribution models in ecology. Ecological Modelling 135, 147-186.

Hamilton III, W.J., Gilbert, W.M., Heppner, F.H. \& Planck, R.J. 1967. Starling Roost Dispersal and A Hypothetical Mechanism Regulating Rhythmical Animal Movement to and from Dispersal Centers. Ecology 48, 825-833.

Hamilton III, W.J. \& Watt, K.E.F. 1970. Refuging. Annual Review of Ecology and Systematics 1, 263-287.

Heikkinen, R.K., Luoto, M., Kuussaari, M. \& Pöyry, J. 2005. New insights into butterfly-environment relationships using partitioning methods. Proceedings of the Royal Society B-Biological Sciences 272, 2203-2210.

Heikkinen, R.K., Luoto, M., Virkkala, R. \& Rainio, K. 2004. Effects of habitat cover, landscape structure and spatial variables on the abundance of birds in an agricultural-forest mosaic. Journal of Applied Ecology 41, 824-835.

Hubbell, S.P., Ahumada, J.A., Condit, R. \& Foster, R.B. 2001. Local neighborhood effects on long-term survival of individual trees in a neotropical forest. Ecological Research 16, 859-875.

Keitt, T.H., Bjornstad, O.N., Dixon, P.M. \& Citron-Pousty, S. 2002. Accounting for 
spatial pattern when modeling organism-environment interactions. Ecography 25, 616-625.

Legendre, P. 1993. Spatial Autocorrelation - trouble or new paradigm. Ecology 74, 1659-1673.

Legendre, P., Dale, M.R.T., Fortin, M.J., Casgrain, P. \& Gurevitch, J. 2004. Effects of spatial structures on the results of field experiments. Ecology $85,3202-$ 3214.

Legendre, P. \& Fortin, M.J. 1989. Spatial Pattern and Ecological Analysis. Vegetatio 80, 107-138.

Legendre, P. \& Legendre, L. 1998. Numerical ecology. Developments in environmental modelling, vol. 20. Elsevier, Amsterdam.

Lichstein, J.W., Simons, T.R., Shriner, S.A. \& Franzreb, K.E. 2002. Spatial autocorrelation and autoregressive models in ecology. Ecological Monographs 72, 445-463.

Luoto, M., Virkkala, R., Heikkinen, R.K. \& Rainio, K. 2004. Predicting bird species richness using remote sensing in boreal agricultural-forest mosaics. Ecological Applications 14, 1946-1962.

Mac Nally, R. 2000. Regression and model-building in conservation biology, biogeography and ecology: The distinction between and reconciliation of 'predictive' and 'explanatory' models. Biodiversity and Conservation 9, 655671.

Mac Nally, R. 2002. Multiple regression and inference in ecology and conservation biology: further comments on identifying important predictor variables. Biodiversity and Conservation 11, 1397-1401.

Mathsoft 2000. S-Plus 2000. Professional edition for Windows. Mathsoft, Seattle, Washington, USA.

Olea, P.P. \& De Frutos, A. 2006. Using the Hierarchical Partitioning PublicDomain Software: Implications in Environmental Management and Conservation. Submitted for publication.

Olea, P.P., Vera, R., De Frutos, A. \& Robles, H. 2004. Premigratory communal roosts of the Lesser Kestrel in the boreal summer. Journal of Raptor Research 38, 278-282.

Oppel, S., Schaefer, H.M., Schmidt, V. \& Schroder, B. 2004. Habitat selection by the pale-headed brush-finch (Atlapetes pallidiceps) in southern Ecuador: implications for conservation. Biological Conservation 118, 33-40.

Overmars, K.P., de Koning, G.H.J. \& Veldkamp, A. 2003. Spatial autocorrelation in multi-scale land use models. Ecological Modelling 164, 257-270.

Parr, S.J., Naveso, M.A. \& Yarar, M. 1997. Habitat and potential prey surrounding lesser kestrel Falco naumanni colonies in central Turkey. Biological Conservation 79, 309-312.

Pont, D., Hugueny, B. \& Oberdorff, T. 2005. Modelling habitat requirement of European fishes: do species have similar responses to local and regional environmental constraints? Canadian Journal of Fisheries and Aquatic 
Sciences 62, 163-173.

Posillico, M., Alberto, M.I.B., Pagnin, E., Lovari, S. \& Russo, L. 2004. A habitat model for brown bear conservation and land use planning in the central apennines. Biological Conservation 118, 141-150.

Pribil, S. \& Picman, J. 1997. The importance of using the proper methodology and spatial scale in the study of habitat selection by birds. Canadian Journal of Zoology-Revue Canadienne de Zoologie 75, 1835-1844.

Quinn, G.P. \& Keough, M.J. 2002. Experimental design and data analysis for biologists. Cambridge University Press, Cambridge, UK.

Radford, J.Q. \& Bennett, A.F. 2004. Thresholds in landscape parameters: occurrence of the white-browed treecreeper Climacteris affinis in Victoria, Australia. Biological Conservation 117, 375-391.

Rushton, S.P., Ormerod, S.J. \& Kerby, G. 2004. New paradigms for modelling species distributions? Journal of Applied Ecology 41, 193-200.

Sanderson, R.A., Eyre, M.D. \& Rushton, S.P. 2005. Distribution of selected macroinvertebrates in a mosaic of temporary and permanent freshwater ponds as explained by autologistic models. Ecography 28, 355-362.

Sawada, M. 1999. ROOKCASE: an Excel 97/2000 visual basic (VB) add-in for exploring global and local spatial autocorrelation. Bulletin of the Ecological Society of America 80, 231-234.

Seoane, J., Bustamante, J. \& Díaz-Delgado, R. 2004b. Are existing vegetation maps adequate to predict bird distributions? Ecological Modelling 175, 137149.

Seoane, J., Bustamante, J. \& Díaz-Delgado, R. 2004a. Competing roles for landscape, vegetation, topography and climate in predictive models of bird distribution. Ecological Modelling 171, 209-222.

Seoane, J., Viñuela, J., Díaz-Delgado, R. \& Bustamante, J. 2003. The effects of land use and climate on red kite distribution in the Iberian peninsula. Biological Conservation 111, 401-414.

Serrano, D., Forero, M.G., Donázar, J.A. \& Tella, J.L. 2004. Dispersal and social attraction affect colony selection and dynamics of lesser kestrels. Ecology 85, 3438-3447.

Serrano, D., Tella, J.L., Forero, M.G. \& Donázar, J.A. 2001. Factors affecting breeding dispersal in the facultatively colonial lesser kestrel: Individual experience vs. conspecific cues. Journal of Animal Ecology 70, 568-578.

Siegfried, W.R. \& Skead, D.M. 1971. Status of the Lesser Kestrel in South Africa. Ostrich 42, 1-4.

Suárez-Seoane, S., Osborne, P.E. \& Alonso, J.C. 2002. Large-scale habitat selection by agricultural steppe birds in Spain: identifying species-habitat responses using generalized additive models. Journal of Applied Ecology 39, 755-771.

Tan, C.O. \& Beklioglu, M. 2005. Catastrophic-like shifts in shallow Turkish lakes: a modeling approach. Ecological Modelling 183, 425-434. 
Tella, J.L., Forero, M.G., Hiraldo, F. \& Donázar, J.A. 1998. Conflicts between lesser Kestrel conservation and European agricultural policies as identified by habitat use analyses. Conservation Biology 12, 593-604.

Ursúa, E. \& Tella, J.L. 2001. Unusual large communal roosts of Lesser Kestrel in two electric substations of Northern Spain: implications for the conservation of Spanish population, In Abstracts of the $4^{\text {th }}$ Eurasian Congress on Raptors. eds J. Bustamante, G. Crema, E. Casado, J. Seoane, C. Alonso, C. Rodríguez, M. de Lucas, G. Janss, p. 188. Estación Biológica de Doñana and Raptor Research Foundation, Sevilla, Spain.

Viñuela, J. 1997. Road transects as a large-scale census method for raptors: The case of the Red Kite Milvus milvus in Spain. Bird Study 44, 155-165.

Virkkala, R., Luoto, M. \& Rainio, K. 2004. Effects of landscape composition on farmland and red-listed birds in boreal agricultural-forest mosaics. Ecography 27, 273-284.

Vlachos, C., Bakaloudis, D., Chatzinikos, E., Papadopoulos, T. \& Tsalagas, D. 2003. Aerial hunting behaviour of the Lesser Kestrel Falco naumanni during the breeding season in Thessaly (Greece). Acta Ornithologica 38, 129-134.

Walsh, C. \& Mac Nally, R. 2004. "The hier.part Package" version 1.0. Hierarchical Partitioning. Documentation for $\mathrm{R}$ : A language and environment for statistical computing. $\mathrm{R}$ Foundation for statistical Computing, http://www.rproject.org. 


\section{Capítulo 2.2}

Importancia de las áreas premigratorias en la conservación del Cernícalo

Primilla: uso del espacio y selección de hábitat durante el periodo premigratorio

Importance of the premigratory areas for the conservation of lesser kestrel: space use and habitat selection during the post-fledging period. De Frutos, A. \& Olea, P.P. 2008. Animal Conservation 11, 224-233. 


\section{Resumen}

La importancia que tiene el periodo premigratorio en la conservación de las aves migradoras ha sido escasamente evaluada. En este estudio se examina el uso del espacio y la selección de hábitat por parte de cernícalos primillas Falco naumanni radiomarcados durante el verano a dos escalas espaciales diferentes. El análisis se realizó en el noroeste de España, donde se producen concentraciones premigratorias de casi 1000 cernícalos primillas. Para estimar el uso del espacio se utilizó el método de kernel que tuvo en cuenta la autocorrelación espaciotemporal de las radiolocalizaciones. Para la selección de hábitat se usó el análisis composicional ponderado, que tuvo en cuenta la intensidad de uso. Los cernícalos primillas se desplazaron hasta $9 \mathrm{~km}$ del dormidero durante el día y retornaron al mismo dormidero al atardecer (comportamiento de refugio). Se alimentaron a $3.7 \mathrm{~km}$ del dormidero de promedio en un área de 346.8 ha (área de campeo), de las cuales usaron intensamente 92.7 ha ("core area"). Dentro de estas áreas, los primillas usaron más el área agrícola que cualquier otro hábitat a escala de paisaje. Dentro del hábitat agrícola, evitaron significativamente los cultivos de regadío. Esto puede ser debido a la dificultad de acceso y/o a la escasez de presas disponibles. Los planes de conservación del Cernícalo Primilla deberían considerar el periodo premigratorio mediante la protección legal de los lugares usados como dormideros y mediante el mantenimiento del sistema cerealista tradicional de secano en torno a ellos. 


\begin{abstract}
The conservation importance of the post-fledging period in migratory birds has been scarcely assessed. In this study, we examined the space use and habitat selection of radio-tagged lesser kestrels Falco naumanni at two spatial scales during summer in northwestern Spain, where premigratory aggregations of around 1,000 lesser kestrels occur. Space use was estimated by kernel accounting for the spatiotemporal autocorrelation of the radio-locations and habitat selection was analysed by weighted compositional analysis accounting for the intensity of use. Kestrels move within $9 \mathrm{~km}$ around roosts during daylight and returned daily during sunset to the same roosts, exhibiting refuging behaviour. They foraged on average $3.7 \mathrm{~km}$ from the roost in an area of 346.8ha (home range), 92.7ha of which were used intensively (core area). Within these areas, lesser kestrels intensively used more farmland than any land-scale habitat. Within farmland, kestrels significantly avoided the irrigated crops. This avoidance seemed to be due to the difficulty of prey access and/or scarcity of prey available. Conservation plans of lesser kestrel should include the post-fledging period by legally protecting roost sites and maintaining dry farmland systems around the communal roosts.
\end{abstract}

Keywords: Falco naumanni, post-fledging period, habitat use, radiotracking, irrigation, roosts 



\section{Introduction}

The post-fledging period in migratory birds is considered to be a part of the avian life-cycle scarcely known (Rappole \& Ballard, 1987; Baker, 1993; Rivera et al., 1998). It has been defined as the period ranging from fledging to departure on fall migration (Rivera et al., 1998; Rivera et al., 1999; Pagen et al., 2000) and can last several months in some bird species [e.g. up to two months for lesser kestrels Falco naumanni (Olea et al., 2004)]. The lack of knowledge of this period is mainly due to the difficulties of observing individuals either because they usually are more inconspicuous in their breeding areas (e.g. they stop singing (Rappole \& Ballard, 1987)] or because they leave their breeding areas prior to migration to remain in premigratory areas (Rappole \& Ballard, 1987; Rivera et al., 1999; Olea et al., 2004). Consequently, the ecological and conservation importance of the post-fledging period for migratory bird species is still not well known in spite of its importance due to birds must build up fat reserves (Rivera et al., 1999) and molt (at less partly; see Rivera et al., 1998) prior the fall migration. Because molting is a demanding process in terms of energy, the availability of sufficient food resources during molting is important not only for their survival but also for their conservation. However, conservation strategies of migratory birds usually regard only the breeding and wintering periods (e.g. Rivera et al., 1998; Mabey \& Watts, 2000), ignoring other stages in which individuals may move or disperse into others different areas (e.g. stopover areas [Petit, 2000] and premigratory areas [see Olea, 2001; Olea et al., 2004]). These areas could play an important role in survival, dispersal, and recruitment processes of the population (e.g., for post-fledging period see Penteriani et al., 2004; Sergio et al, 2004). However, the factors limiting and regulating the populations of migratory birds are still poorly known during these stages, jeopardizing consequently the efficacy of migratory bird conservation and management. For instance, the post-fledging period is not taken into account in the International Action Plan for the lesser kestrel (Biber, 1996). Here, we studied a population of a threatened migratory bird species, the lesser kestrel, during the post-fledging period. 
Lesser kestrel is considered to be a globally threatened species listed as Vulnerable (BirdLife International, 2007). This migratory species is a small falcon breeding in the Palaearctic and wintering mainly in Africa (Siegfried \& Skead, 1971; Cramp \& Simmons, 1980). After breeding the post-fledging dependence period of lesser kestrels is short, in which juveniles gain independence from their parents very soon after fledging (5 days; Bustamante \& Negro, 2004) and move large distances from natal sites prior to migration (Olea, 2001). Large aggregations of lesser kestrels occur during the post-fledging period (i.e. in summer) in several Spanish areas where population size attains to be several orders of magnitude larger than local breeding populations, suggesting that part of these postbreeding populations come from other areas (Olea, 2001; Ursúa \& Tella, 2001; Olea et al., 2004). The areas occupied during summer by lesser kestrels at least during 2-2.5 months have been suggested to be regular premigratory areas and have ecological and conservation importance for lesser kestrel populations (Olea et al., 2004). Spatial pattern of lesser kestrel abundance in the premigratory areas has been not clearly explained by landscape variables (De Frutos et al., 2007), highlighting the need of studies more detailed on habitat selection and space use at different scales to improve the understanding of the post-fledging biology and the efficacy of lesser kestrel conservation and management programmes.

In this study we radiotagged lesser kestrels in a premigratory area for examining the space use and habitat selection during the post-fledging period. We (1) examined the movements of lesser kestrels during the post-fledging using radiotracking, (2) we determined both their homerange and core-area sizes taking into account the autocorrelation of lesser kestrel locations, and (3) we evaluated habitat selection at multiple spatial scales taking into account the intensity of use for each habitat type using the Weighted Compositional Analysis. 


\section{Material and methods}

\section{Study area}

The study was conducted in a $1,200 \mathrm{~km}^{2}$ area in northwestern Spain (centred at $5^{\circ} 15^{\prime} \mathrm{W} 42^{\circ} 17^{\prime} \mathrm{N}$; Fig. 1). The landscape is flat with low hill and scarcely vegetated with little amounts of trees. The dominant habitat is extensive dry farmland, in rotation every other year. Dry cereals and ploughed fields dominate the agricultural landscape. When we carried out the study, almost all the dry cereal cultures had been harvested, remaining as stubbles and being exploited by a low grazing intensity (De Frutos et al., 2007). During summer this area holds a large post-breeding lesser kestrel population (800-1200 birds; Olea et al., 2004; pers. obs.) which gathers in 4 communal roosts at night (Fig.1); these roosts have been used each year for at least 7 years (Olea et al., 2004, obs. pers.).

\section{Trapping and marking}

We captured lesser kestrels at two roosts (A and B) of the four located in the study area (Fig. 1). Both roosts were separated by $24.5 \mathrm{~km}$ and were made up of scattered holm oaks (Quercus ilex) between 3-8 meters high. The maximum number of lesser kestrels counted in roost $A$ was 138 and 270 in 2004 and 2005 respectively, while in roost B was 280 in 2004 and 2005. Birds in roost A was trapped in summer of 2004 and 2005, whereas in roost B only in 2004. To capture lesser kestrels we set a net that partly covered the roosting trees 2 hours before sunset (i.e. before lesser kestrels gathered at the roost; see Olea et al., 2004). Lesser kestrels were captured by flushing out them at full night while roosting. We fitted VHF radio-transmitters to 17 lesser kestrels (8 in 2004 and 9 in 2005) over the synsacrum using a figure-8 harness with two loops that slide over the legs (Rappole \& Tipton, 1991). After radio-tagging the captured birds were released at the same trees that used as roost. Captured lesser kestrels used the same roost at the next days at that of its capture. Although no negative effects have been detected using tailattached transmitters (Donázar, Negro \& Hiraldo, 1993; Tella et al., 1998; Franco et al., 2004), studies on the impact of the transmitters mounted with body harness on lesser kestrel are lack. Transmitters (PD-2, Holohil System Ldt., Ontario, Canada) weighted $2.3 \mathrm{~g}$ (approximately $1.6 \%$ of mean lesser kestrel mass) and had a life expectancy of 3 months. 


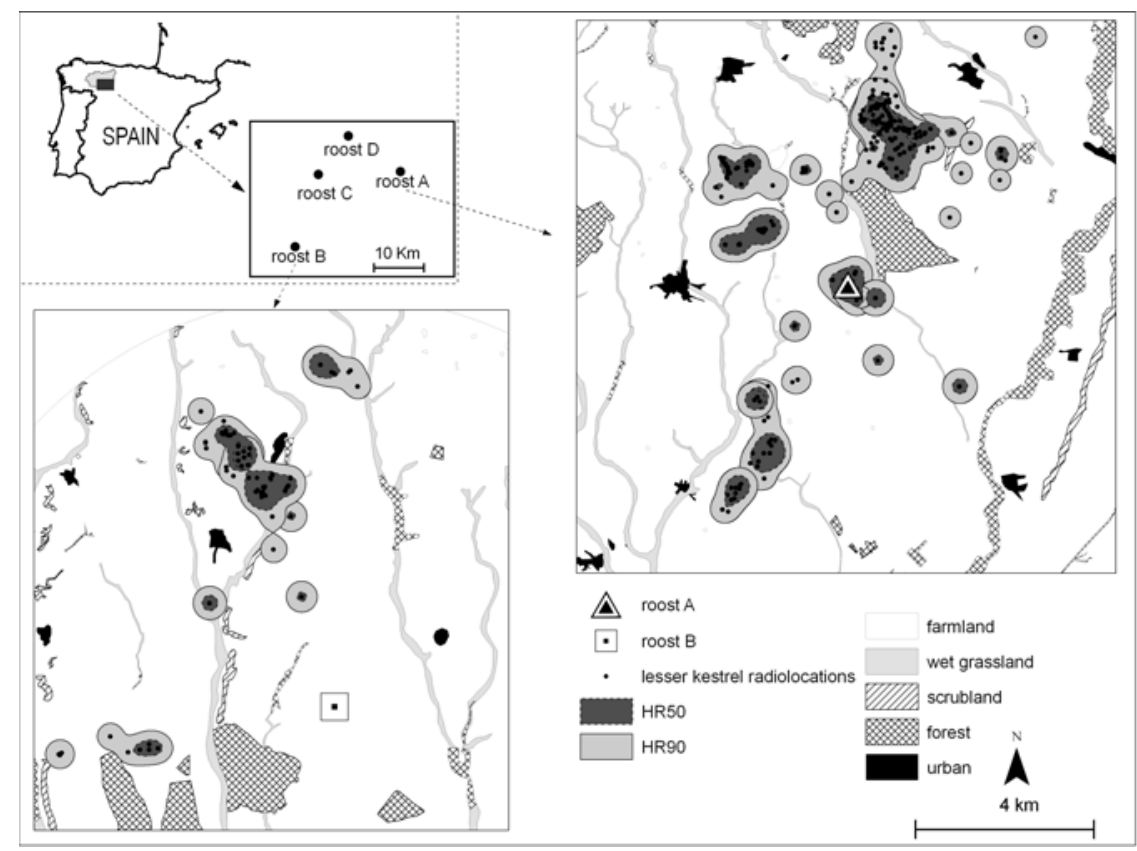

Figure 1. Location of the study area showing the communal roosts of lesser kestrels used during summers of 2004 and 2005. Radiolocations (black spots; $n=6546$; many of them are clumped) of the 9 tagged lesser kestrels in roost $A$ (triangle) and B (square), their home range 90\% (see text; shaded area with solid outline) and home range $50 \%$ (shaded area with dashed outline). Note that home ranges of lesser kestrels monitored during 2004 and 2005 at roost A are showed together.

\section{Radio-tracking}

We monitored radio-tagged lesser kestrels from first day after bird tagging until the transmitter failed to remain attached or bird dispersed from the study area (14 Aug-19 Sept in 2004, and 28 Jul-16 Sept in 2005; this accounts for a substantial portion $(>50 \%)$ of the post-fledging period; Table 1). Birds were tracked via ground-based homing-in (Kenward, 2001) using a receiver (RX-98E, Televilt, Lindesberg, Sweden) and two handheld or vehicle-mounted 2- or 4-element directional Yagi-antennas (Kenward, 2001). Homing-in technique allows obtaining direct observations and getting very accurate data compared to other tracking methods as triangulation (Mech, 1980). Lesser kestrels were observed directly away from us using binoculars and 20-60x telescopes. Each day two randomly selected birds were searched and followed by one person 
using a car for a $2-4 \mathrm{~h}$ period each bird, between 1 hour after sunrise and 1 hour before sunset (i.e. when the birds were active outside their roosts [Olea et al., 2004]). Once located the bird, we registered locations every 1 min until completing the 2-4 hour session. For each individual location, we recorded $x-y$-coordinate positions, time of detection, habitat type, and bird activity. For analytical purposes, we considered observations of foraging lesser kestrels, including whenthey were perching on posts or on ground (we frequently observed them capturing prey while perching). We only exclude all observations of high speed, directional flights due to birds may fly above unfavourable habitats.

Table 1. Summary of the monitoring for each radio-tagged lesser kestrel $(n=9)$ at two communal roosts in a Spanish farmland during summers of 2004 and 2005, including the day of tagging, the days of monitoring, the days in which each individual was sought but not located, and the amplitude of the monitoring period (number in days between the first and the last radiolocation day).

\begin{tabular}{|c|c|c|c|c|c|c|c|c|}
\hline Year & Roost & Individual & Sex & Age & Tagging & Monitoring & Unlocated & Amplitude \\
\hline \multirow{5}{*}{2004} & \multirow{3}{*}{ A } & 1 & female & adult & 17.08 .2004 & 14 & 8 & 18 \\
\hline & & 2 & female & adult & 17.08.2004 & 4 & 1 & 6 \\
\hline & & 3 & female & adult & 17.08 .2004 & 10 & 4 & 19 \\
\hline & \multirow{2}{*}{ B } & 4 & female & adult & 13.08.2004 & 5 & 0 & 8 \\
\hline & & 5 & male & adult & 13.08.2004 & 12 & 1 & 34 \\
\hline \multirow{4}{*}{2005} & \multirow{4}{*}{ A } & 6 & male & adult & 02.08 .2005 & 24 & 0 & 45 \\
\hline & & 7 & male & adult & 26.07 .2005 & 3 & 0 & 3 \\
\hline & & 8 & male & adult & 08.09 .2005 & 6 & 2 & 4 \\
\hline & & 9 & male & sub-adult & 05.08 .2005 & 25 & 5 & 37 \\
\hline
\end{tabular}

Additionally to the daylight tracking, the roost use at night by radiotagged lesser kestrels was verified by scanning them at night with the telemetry equipment. Since we unknown at first of our study if birds move between roosts, when a bird was not located at its roost we scanned the study area checking all the known roosts at night

\section{Space use}

To examine the space use of tagged lesser kestrels, we firstly estimate the Utilization Distribution (UD), which is a probability density function that quantifies the animal's relative use of space (Van Winkley, 
1975; Silverman, 1986). UD is commonly estimated using the kernel technique (Marzluff et al., 2004; Worton, 1989), which assumes that animal locations are temporally and spatially independent (i.e. not autocorrelated; Harris et al., 1990). As radio-tagged lesser kestrels were located and monitored in irregular time intervals (see below), animal locations were temporally and spatially aggregated, and likely autocorrelated. To overcome this, we used a novel spatiotemporal variant of the kernel technique (TK STW; Katajisto \& Moilanen, 2006) that gives less relative weight to both temporally and spatially aggregated locations. In TK STW analysis, there are two parameters (the temporal [ht] and spatial [hs] smoothing factors) that indicate the time or distance over which locations are temporally or spatially independent, respectively. Prior to TK STW calculations, these both factors must be set. According Katajisto \& Moilanen (2006), we set 0.5 day for $h t$ as tagged lesser kestrels daily left foraging areas to return at the same roost at night (see below, 1 day for time to independence [TTI], $h t \approx \mathrm{TTI} / 2=1$ day $/ 2=0.5$; Katajisto \& Moilanen, 2006). To set $h s$, we combined both the reference method (Silverman, 1986, Worton, 1995) and user-defined selection, as least square cross validation (LSCV) method fails to estimate $h s$ with location patterns with identical or quite clumped locations (as in our case; Seaman 1998; Gitzen \& Millspaugh, 2003). For this, we firstly calculated the median of the $h s$ of each tagged lesser kestrel (Katajisto \& Moilanen, 2006) with the reference method. We set the $0.4,0.5,0.6,0.8$ and 1 times the median $h s$ in TK STW to generate UDs for each lesser kestrel. After a visual exploration of these UDs, we decided which of these values estimated the more realistic UD relative to the observed animal locations (i.e. 0.5 times the median $h$ s which corresponded to $198.3 \mathrm{~m}$ ). This approach, when LSCV method fails, has been recommended by various authors (see forum in www.faunalia.com, C. Callenge, author of "adehabitat package" of R; J. Katajisto pers. com.). TK STW calculations were performed using the B-Range software (Katajisto \& Moilanen, 2006), which calculates the number of effective locations (Neff) by summing the spatiotemporal weighs of the original locations (i.e., the virtual number of spatiotemporally independent observations; Katajisto \& Moilanen, 2006) and yields a digital UD layer. Based on this layer, we calculated the smallest area associated with a $90 \%$ and $50 \%$ probability of the use intensity (HR90 and HR50, respectively), using ArcGis 9.0 (ESRI, 2007). We used HR90 and HR50, as they are considered robust estimators of 
animal space use (Borger et al., 2006). These parameters estimate specifically the home range of animals (Borger et al., 2006) and the area of frequent use (core area; Samuel et al., 1985). To calculate the size of both HR90 and HR50, we used tagged lesser kestrels with a Neff $\geq 10$ for each bird (see Borger et al., 2006, Table 2).

Table 2 Summary of telemetry data for each radio-tagged lesser kestrel $(n=9)$ at two communal roosts in a Spanish farmland during summers of 2004 and 2005, including number of telemetry locations acquired (radio locations), effective number of locations (Neff), home range size, and mean linear distance from the roost to the center of the home range.

\begin{tabular}{cccccc}
\hline \multirow{2}{*}{ Individual } & $\begin{array}{c}\text { Radio } \\
\text { locations }\end{array}$ & Neff & \multicolumn{2}{c}{ Home range size (ha) } & Distance from \\
\cline { 4 - 5 } & & $90 \%$ & $50 \%$ & roost to HR $(\mathrm{km})$ \\
\hline 1 & 600 & 13.12 & 234.2 & 60.1 & 1.7 \\
2 & 490 & 21.6 & 276.5 & 68.9 & 3.3 \\
3 & 189 & 11.65 & 344.5 & 112.8 & 2.9 \\
4 & 266 & 14.9 & 217.6 & 59.6 & 5.8 \\
5 & 1045 & 35.4 & 622.8 & 153.8 & 5.4 \\
6 & 1893 & 83.12 & 318.2 & 80.7 & 4.1 \\
7 & 966 & 68.6 & 434.8 & 135.8 & 2.6 \\
8 & 237 & 73.71 & 192.7 & 59.4 & 3.6 \\
9 & 860 & 49.8 & 480 & 103.5 & 3.4 \\
\hline mean & 727.3 & 41.3 & 346.8 & 92.7 & 3.7 \\
median & 600 & 35.4 & 318.2 & 80.7 & 3.4 \\
\hline
\end{tabular}

\section{Habitat selection}

\section{Spatial scales}

Johnson (1980) and Aebischer et al., (1993) recommended to asses the habitat selection at multiple spatial scales. This approach allows accounting for hierarchical differences in the selection process. Accordingly, we evaluated habitat selection at two scales: 1) at the studyarea scale (SA scale, hereafter), and 2) at the home-range scale (HR scale, hereafter). At the SA scale the analysis examines whether animal home ranges are placed randomly in the study area with respect to habitat composition; and at the HR scale the analysis examines the habitat selection within an individual home range relative to the habitat availability measured within that home range. 


\section{Measurement of habitat availability}

For the SA scale, available habitat for lesser kestrels was measured within the area delimited by a 9-km radius around each roost (i.e. the distance of the outermost radio location registered pooling all radio-tagged lesser kestrels; see below); whereas for the HR scale, available habitat was measured within HR of each bird.

The available habitat within each scale (SA and HR) was measured in turn at two scales: landscape-scale habitat and fine-scale habitat. Five landscape-scale habitats were considered: farmland, wet grassland (pastures associated mainly with river beds), forest, urban, and scrubland areas (Table 3). Available habitat was considered as the relative proportions of each habitat. For this, we estimated these proportions from a digital land-use layer obtained from aerial photographs using ArcGis 9.0. Regarding the fine-scale habitats, we only measured those within farmland due to this landscape-scale habitat was the most used (the intensity of use by tagged lesser kestrel was on average of $96.2 \% \pm 3.9$; see below). Thus, we considered crop types (dry cereal stubbles, plugged fields, fallows, leguminous crops, and irrigated crops; Table 4) and field margins (strips with grass vegetation separating fields from roads).

In our study area, farmland is made up by a large mosaic of crop fields meaning a logistic problem to measure on-ground this entire habitat on a large area. For this reason, at the SA scale, availability of each crop type and field margins (Table 4) was estimated by measuring it on-ground in $25-321 \mathrm{~km}^{2}$ squares emplaced randomly within the area delimited by a 9-km radius around each roost. To asses whether these sample sizes of squares were adequate to estimate the fine-scale habitat availability, we firstly created accumulation curves by plotting the relative proportion accumulated of each crop type and field margins as a function of number of sampled squares (Figure 2, only cereal stubble, fallow and irrigated crop are shown). This procedure showed to be adequate to measure the fine-scale habitat availability with a minimum sample size of $201-\mathrm{km}^{2}$ squares around each roost. 
Table 3. Proportion of used landscape-scale habitat (proportion of the intensity of use; see text) by lesser kestrels radio-tagged $(n=9)$ within their $90 \%$ home range at two communal roosts in a Spanish farmland during summers of 2004 and 2005. Roost $A$ and $B$ shows the available habitat measured within the area delimited by a $9-\mathrm{km}$ radius around each roost.

\begin{tabular}{cccccc}
\hline Individual & Farmland & Urban & Scrubland & Forest & Wet grassland \\
\hline 1 & 98.9 & 0.0 & 0.0 & 0.0 & 0.9 \\
2 & 99.6 & 0.0 & 0.0 & 0.0 & 0.2 \\
3 & 92.5 & 0.0 & 7.5 & 0.0 & 0.0 \\
4 & 98.1 & 0.0 & 0.0 & 0.5 & 1.4 \\
5 & 88.4 & 0.0 & 0.1 & 0.4 & 10.7 \\
6 & 98.9 & 0.0 & 1.0 & 0.1 & 0.0 \\
7 & 98.5 & 0.0 & 0.0 & 0.2 & 1.3 \\
8 & 98.2 & 0.0 & 0.0 & 0.1 & 1.6 \\
9 & 93.0 & 0.0 & 6.6 & 0.3 & 0.0 \\
\hline Roost A & 87.7 & 1.5 & 0.8 & 6.9 & 2.9 \\
Roost B & 87.9 & 0.9 & 0.6 & 6.5 & 4.1 \\
\hline
\end{tabular}

Table 4. Proportion of used fine-scale habitat (proportion of the intensity of use; see text) by lesser kestrels radio-tagged $\left(n=7^{*}\right)$ within their $50 \%$ home range (HR50) at two communal roosts in a Spanish farmland during summers of 2004 and 2005. Roost A and B shows the available habitat measured within the area delimited by a $9-\mathrm{km}$ radius around each roost for each year.

\begin{tabular}{ccccccc}
\hline Individual & $\begin{array}{c}\text { Plugged } \\
\text { fields }\end{array}$ & Fallows & $\begin{array}{c}\text { Leguminous } \\
\text { crops }\end{array}$ & $\begin{array}{c}\text { Dry cereal } \\
\text { stubbles }\end{array}$ & $\begin{array}{c}\text { Irrigated } \\
\text { crops }\end{array}$ & Field margins \\
\hline 1 & 27,0 & 20,7 & 0,0 & 43,8 & 6,4 & 0,8 \\
2 & 26,3 & 0,8 & 0,0 & 70,5 & 0,0 & 1,1 \\
3 & 28,9 & 10,5 & 0,0 & 49,0 & 0,0 & 1,3 \\
4 & 8,8 & 12,8 & 7,1 & 69,8 & 0,0 & 0,9 \\
5 & 19,2 & 5,9 & 3,7 & 56,0 & 0,0 & 1,1 \\
6 & 53,6 & 0,8 & 3,4 & 41,1 & 0,0 & 0,7 \\
9 & 36,9 & 6,4 & 3,5 & 46,5 & 0,0 & 1,0 \\
\hline Roost A (2004) & 25,5 & 6,4 & 0,6 & 41,9 & 3,4 & 1,6 \\
Roost A (2005) & 19,6 & 5,4 & 1,3 & 45,9 & 3,1 & 1,8 \\
Roost B (2004) & 32,5 & 6,3 & 1,5 & 33,7 & 2,1 & 1,2 \\
\hline
\end{tabular}



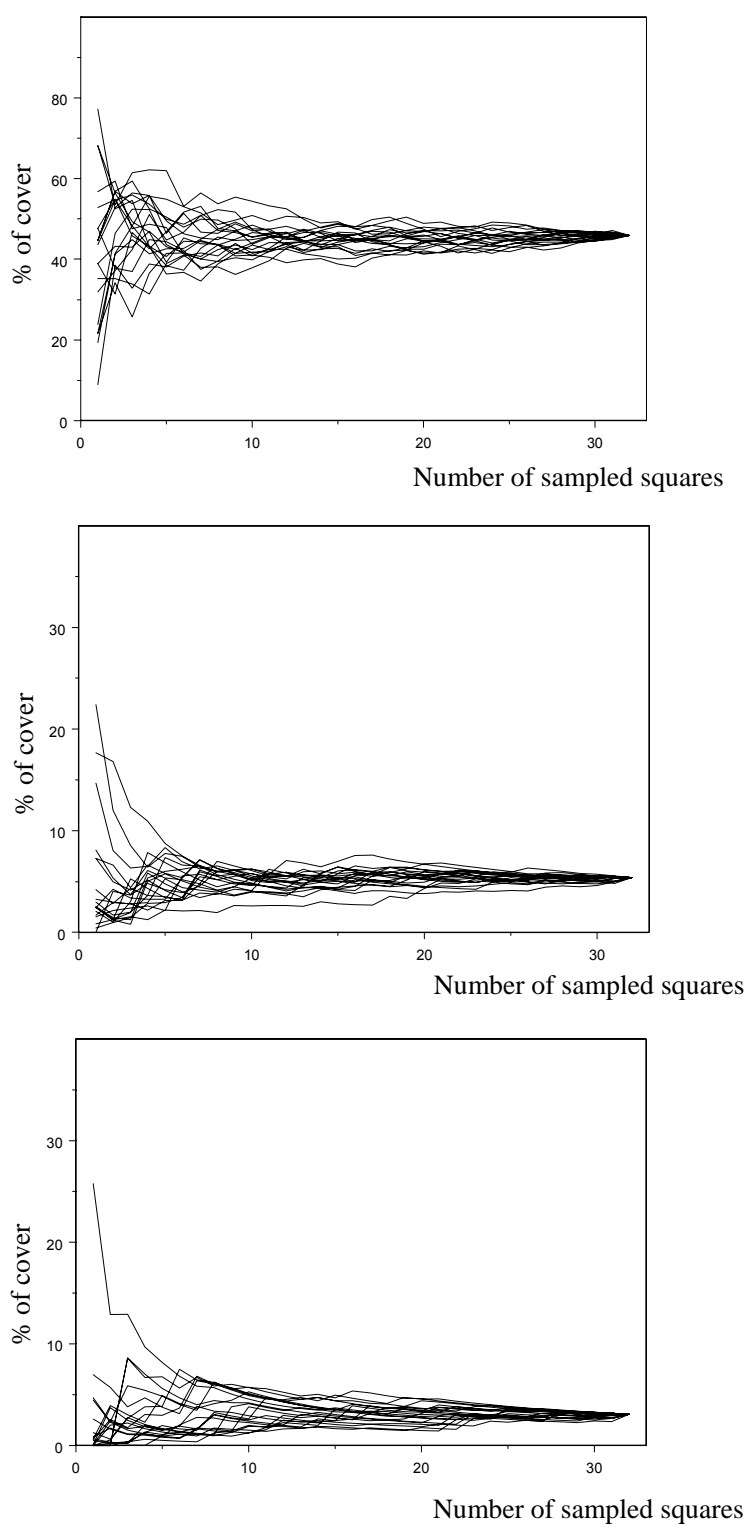

Figure 2. Accumulation curve of the relative proportion accumulated of a) dry cereal stubble crops, b) fallow, and c) irrigated crops as a function of the number of sampled squares ( $n$ total $=321 \mathrm{~km}^{2}$ squares) around the A communal roost of lesser kestrel in a Spanish farmland during summer 2005. Accumulation curves were created from 20 randomizations of sample order. Each line represents a randomization. 
The availability of fine-scale habitats at the HR scale was estimated on-ground only within HR50, since HR90 of all birds together comprised a large area meaning a logistic problem to measure completely the finescale habitat.

\section{Statistical analysis}

We evaluated habitat selection by radio-tagged lesser kestrels using a novel variant of the Compositional Analysis (CA, Aebischer et al., 1993), the Weighted Compositional Analysis (WCA; Millspaugh et al., 2006). WCA not only compares the proportions of each used habitat type with respect to their available proportions, but it also takes into account the intensity of use for each habitat type (Millspaugh et al., 2006). Used habitat by lesser kestrels was the proportion of the intensity of use (i.e. the value of UD). WAC analysis was performed using the "adehabitat package" version 1.4 (Calenge, 2006), which was run in the R statistical software $(R, 2006)$.

\section{Results}

\section{Radiotracking and space use}

We tracked successfully nine radio-tagged lesser kestrels (Table 1). They were monitored during an average of 9.1 days $(S D=7.8$; range 3-24 days; Table 1). Sizes of home range and core area were estimated using on average an Neff of 41.3 radio locations for each bird ( $S D=28.3$; range=11.65-83.12). When the spatio-temporal autocorrelation was taken into account, the Neff of radio locations averaged $7.8 \%$ (range $=2.2-31.1 \%$ ) of locations from the original data ( $n=6546$ original locations; mean $\pm S D$ : $727.3 \pm 542.0$ ), indicating thus the presence of high spatio-temporal autocorrelation. The Neff of locations was not significantly correlated to HR90 and HR50 sizes (for HR90: $r_{s}=0.065, P=0.87, n=9$ birds; for HR50: $r_{s}<0.001, P=1.0, n=9$ birds). HR90 and HR50 sizes were not significantly correlated to the amplitude of the monitoring period (number of days between the first and the last radiolocation day; for HR90: $r_{s}=0.511, P=0.08, n=9$ birds; for HR50: $r_{s}=0.293, P=0.22, n=9$ birds). We found no significant differences in HR90 and in HR50 sizes 
between male and female (Mann-Whitney $U$-tests; $p=0.33$ and $P=0.21$, respectively), between study years $(P=0.87$ and $P=1.0)$ nor between roosts $(P=0.77$ and $P=0.77$ ); thus, data for each sex, year and roost were pooled prior home-range analysis. Mean HR90 size of tagged lesser kestrel was 346.8 \pm 141.6 ha (range 622.8-127ha, $n=9$ birds), and 92.7 \pm 35.5 ha (range 153.8 - 59.4ha, $n=9$ birds) for mean HR50 size (Table 2; see Fig. 1). The mean linear distance from the roost to the center of the HR90 was $3.7 \pm 1.3 \mathrm{~km}$ (range $1.7-5.8 \mathrm{~km}, n=9$ birds). All lesser kestrel radio locations were registered within $9 \mathrm{~km}$ from the roost in all study years. In roost $A$, the maximum registered distance from roost to the foraging place was of $5.0 \mathrm{~km}$ in 2004 and of $8.9 \mathrm{~km}$ in 2005; whereas it was of $7.6 \mathrm{~km}$ in roost B in 2004 . Each monitored tagged lesser kestrel returned daily during sunset to the same roost where it was captured. No change of roost by tagged lesser kestrel was reported.

\section{Habitat selection by tagged kestrels}

\section{Landscape-scale habitats}

Lesser kestrels used mainly farmland within HR90 (mean farmland $=96.2 \pm 3.9 \%$ per used habitat). At the SA scale, WCA results showed that lesser kestrels did not establish their HR90 at random within a $9-\mathrm{km}$ radius from the center of any roost (Lambda $=0.00016, P=0.008$, see Table 5). The ranking habitat in decreasing order of selection by lesser kestrel was: farmland $>$ wet grassland $>$ scrubland $>$ forest $>$ urban areas (see Table 5). Farmland was significantly more used than any other habitat, while urban areas were significantly the least utilized habitat. There was no detectable significant difference in use among the other three habitats.

At the HR scale, urban areas were absent from the HR90 of all birds, while scrubland was it from the HR90 of $>50 \%$ of birds. To reduce effects of inflated Type I error rates on our results, urban areas and scrubland were excluded (see Aebischer et al., 1993; Bingham \& Brennan, 2004). At this scale, habitat selection by lesser kestrel was similar to the SA scale (Lambda=0.0418, $P=0.01$, Table 5), with farmland as the significantly more used habitat, and with no detectable differences between the use of wet grassland and forest (Table 5). 
Fine-scale habitats

At the SA scale, WCA results showed that habitat use was nonrandom (Lambda $=0.0084, P=0.028$, Table 6 ), with irrigated crops as the significantly less used habitat. The decreasing order of selection by lesser kestrel of the remaining five habitats was: dry cereal stubbles > plugged fields > fallows > field margins > leguminous crops (Table 6), although this ranking habitat was no significant.

At the HR scale, irrigated crops were absent from the HR50 of all birds except for one, so this habitat was dropped in the within-HR50 comparisons (see above). At this scale, WCA results indicated that radiotagged lesser kestrel were nonselective in their fine-scale habitat selection (Lambda=0.3924, $P=0.66$ ).

Table 5. Landscape-scale habitat selection at both the study-area and homerange $90 \%$ scales as determined by weighted compositional analysis of lesser kestrel radio-tagged $(n=9)$ at two communal roosts in a Spanish farmland during summers of 2004 and 2005.

\begin{tabular}{lccccc}
\hline \multirow{2}{*}{ Habitat type } & \multicolumn{2}{c}{ Study-area scale } & & \multicolumn{2}{c}{ Home-range 90\% scale } \\
\cline { 2 - 3 } \cline { 5 - 6 } & $\begin{array}{c}\text { Habitat } \\
\text { rank }^{a}\end{array}$ & $\begin{array}{c}\text { Rank } \\
\text { differences }\end{array}$ & & $\begin{array}{c}\text { Habitat } \\
\text { rank }^{\text {a }}\end{array}$ & $\begin{array}{c}\text { Rank } \\
\text { differences }^{b}\end{array}$ \\
\hline Farmland & 4 & $\mathrm{~A}$ & & 2 & $\mathrm{~A}$ \\
Wet grassland & 3 & $\mathrm{~B}$ & & 1 & $\mathrm{~B}$ \\
Scrubland & 2 & $\mathrm{~B}$ & & - & - \\
Forest & 1 & $\mathrm{~B}$ & & 0 & $\mathrm{~B}$ \\
Urban & 0 & $\mathrm{C}$ & & - & - \\
\hline
\end{tabular}

${ }^{a}$ Following Aebischer et al. 1993, habitat was ranked in order of increasing relative use, where 0 is the less used habitat.

${ }^{b}$ WCA analysis indicated that habitat types with the same letter code were not different $(p>0.05)$ from each other.

Note: "-" indicates that the habitat was excluded from the analysis (see text). 
Table 6. Selection of fine-scale habitat of farmland at both the study-area and home-range $50 \%$ scales as determined by weighted compositional analysis of lesser kestrel radio-tagged $\left(n=7^{*}\right)$ at two communal roosts in a Spanish farmland during summers of 2004 and 2005.

\begin{tabular}{|c|c|c|c|c|}
\hline \multirow[b]{2}{*}{ Habitat type } & \multicolumn{2}{|c|}{ Study-area scale } & \multicolumn{2}{|c|}{ Home-range $50 \%$ scale $^{c}$} \\
\hline & $\begin{array}{l}\text { Habitat } \\
\text { rank }^{\mathrm{a}}\end{array}$ & $\begin{array}{c}\text { Rank } \\
\text { differences }^{b}\end{array}$ & $\begin{array}{l}\text { Habitat } \\
\text { rank }^{a}\end{array}$ & $\begin{array}{c}\text { Rank } \\
\text { differences }^{b}\end{array}$ \\
\hline $\begin{array}{l}\text { Dry cereal } \\
\text { stubbles }\end{array}$ & 5 & $A$ & 3 & A \\
\hline Plugged fields & 4 & $A B$ & 1 & B \\
\hline Fallows & 3 & $A B$ & 0 & $A B$ \\
\hline Field margins & 2 & B & 2 & $A B$ \\
\hline $\begin{array}{l}\text { Leguminous } \\
\text { crops }\end{array}$ & 1 & $A B$ & 4 & $A B$ \\
\hline Irrigated crops & 0 & C & - & - \\
\hline
\end{tabular}

\section{Discussion}

\section{Space use}

Results from this study revealed that radio-tagged lesser kestrels returned daily to the sites used as communal roost at night and foraged in the area around them during daylight. This behaviour agrees with Hamilton's refuging theory, which states that animals would use a roost as a central place within the area of food supply and disperse from this roost daily to forage (Hamilton et al., 1967; Hamilton III \& Watt, 1970). The refuging behaviour exhibited by tagged lesser kestrels indicates high roost fidelity, especially because we did not report tagged lesser kestrels changing of roost within the study area in the same summer. This roost fidelity may suppose an advantageous process to the individual, as the lesser kestrels would be familiar with the area around roost and the local 
food resources, decreasing their search time (see Morrison \& Caccamise, 1990).

The lesser kestrels moved up to $9 \mathrm{~km}$ from the roost, which is in accordance with results of De Frutos et al. (2007), who found that abundance of summering lesser kestrel decreased monotonically with the increase of the distance from roosts up to $9 \mathrm{~km}$.

Lesser kestrels foraged on average $3.7 \mathrm{~km}$ from the roost in an area of 346.8ha. This suggests that home ranges in the premigratory and breeding periods are roughly similar (see Negro, Donázar \& Hiraldo, 1993; Tella et al., 1998; Reis \& Rocha 2001; Franco et al., 2004; LivenSchulman et al., 2004 ). Lesser kestrels (and migratory birds in general) need both to recover their energy reserves invested into breeding and fat for migration during the post-fledging period (Aparicio, 1990). Therefore it is probably that availability of areas with sufficient food supply during this period (e.g. with high densities of Orthoptera, the main preys of lesser kestrel during the post-fledging period [Franco and Andrada, 1977; Tejero, 1982; authors unpubl. data]) may be important for survival and conservation of post-breeding lesser kestrels (Olea et al., 2004). For example, the high postfledging mobility of lesser kestrel juveniles probably seeking food-rich areas (Olea, 2001) might increase their risk of mortality affecting thus population dynamics (see Hiraldo et al., 1996).

Therefore, investigation on post-fledging movements and survival as well as to ascertain the value of the areas used intensively (home ranges) as food resource during the premigratory period is a promising work that would aid to improve the understanding of the post-fledging biology and the efficacy of lesser kestrel conservation and management programmes.

\section{Habitat selection}

Our results revealed that tagged lesser kestrels showed clear preferences of habitat during summer. Lesser kestrels intensively used more farmland than any habitat. Excluding urban, the remaining landscape-scale habitats were used intermediately by lesser kestrels, and the decreasing order of preference: wet grassland, scrubland and forest could be characterized by an increase of cover and height of the vegetation in the study area (pers. obs.), decreasing thus their use by lesser kestrels. This could be due to the lesser accessibility of prey for 
aerial hunting lesser kestrels (see Vlachos et al., 2003; Donázar et al., 1993). The scarce use of scrubland by lesser kestrel is compatible with the negative selection by lesser kestrels during the breeding period reported in other areas (Tella et al., 1998; Franco \& Sutherland, 2004). Scrubland habitat is currently located in natural areas non-cultivated and, to a lesser extent in abandoned crops (pers. obs.). Crop abandonment, however, could also create fallow until the establishment of scrub species, from more or less the fifth year (pers. obs.). Fallow is positively selected by lesser kestrel during the breeding period in some areas (Tella et al., 1998; Franco \& Sutherland, 2004, García et al., 2006). Therefore, crop abandonment at long-term within the used areas by lesser kestrel is not recommended for conservation of lesser kestrel. On the other hand, the negative selection of forest habitat by lesser kestrels we found agrees with previous studies on the species during the breeding period (Donázar et al., 1993, Franco \& Sutherland, 2004). Forest habitat can be increased with the encouragement of the agri-environmental schemes, promoted by the Common Agriculture Policy to farmers to forest their farms (MAPA, 2007). Suggestions for avoiding land abandonment and afforestation have been highly recommended in breeding areas of lesser kestrel (Ursúa, Serrano \& Tella, 2005).

As farmland was the more used habitat, we carried out a detailed analysis within this habitat. Preferences of fine-scale habitat within farmland only showed a significant negative selection of irrigated crops. No significant selection of other crops could be due to the small sample size or to the fact that lesser kestrels use different crop types within farmland habitat according to their availability (with the exception of irrigated crops). Despite weak preferences, tagged lesser kestrels used all the fine-scale habitats (except irrigated crops), so that all these types of crops may be important in any time during the period prior to migration. The avoidance of the irrigated crops could be due to the dense and tall structure of the vegetation of both still unharvested maize $(\approx 200 \mathrm{~cm})$ and irrigated alfalfa $(\approx 60 \mathrm{~cm})$, that would difficult the prey access. Also, this type of crops has an intensive management with chemical treatments that may reduce the abundance of insects prey for lesser kestrel (Donázar et al., 1993; Rodríguez, 2004). Importantly, part of our study area, the surroundings roost $A$, is being transformed into an irrigated zone (MAPA, 2007). Currently, there are almost 863 ha devoted to irrigated crops (i.e., $3.4 \%$ of the total extent of the area around roost $A$ ), but it is expected to 
increase the surface of irrigated crops around this roost (up to 21-62\%) and thus foraging areas of lesser kestrels will be probably reduced. Therefore, irrigation may affect negatively to lesser kestrel numbers in the study area. Although lesser kestrels can select irrigated crops once they have been harvested (Ursúa et al., 2005), in general they are avoided during the winter (Tella \& Forero, 2000), breeding period (Tella et al., 1998 ) and summer (this study). In our area, maize accounts for almost $90 \%$ of the crops once the area is irrigated and remains unharvested throughout summer hampering use by lesser kestrel. Therefore, a significant fraction of this area could turn into unsuitable for use by lesser kestrel if their roosts (namely roost A, C and D; see Fig. 1) and surroundings are not protected against agricultural intensification. We know that roosts within our study area have been used each year by around of 800-1,200 lesser kestrels for at least 7 years (Olea et al., 2004, obs. pers.), but if these birds are flexible in their dispersing behaviours to find other suitable premigratory areas is still unknown. Therefore, given that this irrigation plan is unavoidable and applying the precautionary principle, special agri-environmental measures should be implemented around the lesser kestrel roosts affected (see Ursúa et al., 2005).

Conservation strategies of lesser kestrel should consider the postfledging period by: 1) legally protecting roosts and the area around them at least up to $9 \mathrm{~km}$ (i.e. about $260 \mathrm{~km}^{2}$ of surface), during summer especially from mid august up to migration in mid September coinciding with game period, 2) encouraging the establishment of the current agrienvironmental schemes focusing on agricultural extensification. These agri-environmental schemes may also benefit other farmland birds of our study area, several of which are threatened too (e.g., great bustard Otis tarda and little bustards Tetrax tetrax), 3) preventing the application of highly toxic pesticides that may affect both directly and/or indirectly (by reducing prey abundance) to lesser kestrel (e.g. Ortego et al. 2007), and 4 ) implementing monitoring programs of summer roosts of lesser kestrel and the investigation of other premigratory areas. 


\section{Acknowledgments}

We thank the persons that assisted with fieldwork especially to $E$. Osorio and G. Solano. Junta de Castilla y León provided the capturing and radiotracking licenses. This research was supported financially by the University of León (ULE 2005-08) and partially by Junta de Castilla y León (SEK02B06) and Ministerio de Educación y Ciencia (CGL200605047/BOS). A. F. was financed by FPU predoctoral fellowship of the University of León. C.L. Alados and P. Mateo reviewed earlier drafts of this manuscript. D. Serrano, V. Penteriani and an anonymous referee are acknowledged for the valuable and constructive comments they gave to improve the manuscript.

\section{References}

Aebischer, N.J., Robertson, P.A. \& Kenward, R.E. 1993. Compositional Analysis of Habitat Use from Animal Radio-Tracking Data. Ecology 74, 1313-1325.

Aparicio, J.M. 1990. Actividad, selección del método de caza y balance energético diario de Falco naumanni durante el periodo premigratorio. Ardeola 37, 163-178.

Baker, R.R. 1993. The function of postfledging exploration - a pilot-study of 3 species of passerines ringed in Britain. Ornis Scandinavica 24, 71-79.

Biber, J.P. 1996. International Action Plan for the Lesser Kestrel (Falco naumanni). Cambridge. UK.

Bingham, R.L. \& Brennan, L.A. 2004. Comparison of Type I error rates for statistical analyses of resource selection. Journal of Wildlife Management 68, 206-212.

BirdLife International 2007. Species factsheet: Falco naumanni, ed. BirdLife International. Downloaded from http://www.birdlife.org on 16/11/2007.

Borger, L., Franconi, N., De Michele, G., Gantz, A., Meschi, F., Manica, A., Lovari, S. \& Coulson, T. 2006. Effects of sampling regime on the mean and variance of home range size estimates. Journal of Animal Ecology 75, 1493-1405.

Bustamante, J. \& Negro, J.J. 1994. The postfledging dependence period of the Lesser Kestrel (Falco naumanni) in Southwestern Spain. Journal of Raptor Research 28, 158-163.

Calenge, C. 2006. The package "adehabitat" for the R software: A tool for the analysis of space and habitat use by animals. Ecological Modelling 197, 516-519. 
Cramp, S. \& Simmons, K.E.L. 1980. The Birds of the Western Paleartic. Vol II. Oxford University Press, Oxford.

De Frutos, A., Olea, P.P. \& Vera, R. 2007. Analyzing and modelling spatial distribution of summering lesser kestrel: The role of spatial autocorrelation. Ecological Modelling 200, 33-44.

Donázar, J.A., Negro, J.J. \& Hiraldo, F. 1993. Foraging habitat selection, land-use changes and population decline in the lesser kestrel Falco naumanni. Journal of Applied Ecology 30, 515-522.

ESRI 2007. Environmental Systems Research Institute Inc., Redlands, CA, USA.

Franco, A. \& Andrada, J.A. 1977. Alimentación y selección de presa en Falco naumanni. Ardeola 23, 137-187.

Franco, A.M.A., Catry, I., Sutherland, W.J. \& Palmeirim, J.M. 2004. Do different habitat preference survey methods produce the same conservation recommendations for lesser kestrels? Animal Conservation 7, 291-300.

Franco, A.M.A. \& Sutherland, W.J. 2004. Modelling the foraging habitat selection of lesser kestrels: conservation implications of European Agricultural Policies. Biological Conservation 120, 63-74.

García, J.T., Morales, M.B., Martínez, J., Iglesias, L., De la Morena, E.G., Suárez, F. \& Viñuela, J. 2006. Foraging activity and use of space by Lesser Kestrel Falco naumanni in relation to agrarian management in central Spain. Bird Conservation International 16, 83-95.

Gitzen, R.A. \& Millspaugh, J.J. 2003. Comparison of least-squares crossvalidation bandwidth options for kernel home-range estimation. Wildlife Society Bulletin 31, 823-831.

Hamilton III, W.J., Gilbert, W.M., Heppner, F.H. \& Planck, R.J. 1967. Starling Roost Dispersal and A Hypothetical Mechanism Regulating Rhythmical Animal Movement to and from Dispersal Centers. Ecology 48, 825-833.

Hamilton III, W.J. \& Watt, K.E.F. 1970. Refuging. Annual Review of Ecology and Systematics 1, 263-287.

Harris, S., Cresswell, W.J., Forde, P.G., Trewhella, W.J., Woollard, T. \& Wray, S. 1990. Home-range analysis using radio-tracking data - a review of problems and techniques particularly as applied to the study of mammals. Mammal Review 20, 97-123.

Hiraldo, F., Negro, J.J., Donázar, J.A. \& Gaona, P. 1996. A demographic model for a population of the endangered lesser kestrel in southern Spain. Journal of Applied Ecology 33, 1085-1093.

Johnson, D.H. 1980. The Comparison of Usage and Availability Measurements for Evaluating Resource Preference. Ecology 61, 65-71.

Katajisto, J. \& Moilanen, A. 2006. Kernel-based home range method for data with irregular sampling intervals. Ecological Modelling 194, 405-413.

Kenward, R. 2001. A manual for wildlife radio tagging. Academic Press, San Diego. 
Liven-Schulman, I., Leshem, Y., Alon, D. \& Yom-Tov, Y. 2004. Causes of population declines of the Lesser Kestrel Falco naumanni in Israel. Ibis 146, 145-152.

Mabey, S.E. \& Watts, B.D. 2000. Conservation of landbird migrants: addressing local policy. Studies in Avian Biology 20, 99-108.

MAPA 2007. Ministry of Agriculture, Fisheries and Food., In http://www.mapa.es.

Marzluff, J.M., Millspaugh, J.J., Hurvitz, P. \& Handcock, M.S. 2004. Relating resources to a probabilistic measure of space use: Forest fragments and Steller's Jays. Ecology 85, 1411-1427.

Mech, L.D. 1980. Making the most of radiotracking., In A handbook on biotelemetry and radio tracking: proceedings of an International Conference on Telemetry and Radio Tracking in Biology and Medicine, Oxford, 20-22 March 1979. eds C.J. Amlaner, D.W. Macdonald, pp. 85-95. Pergamon Press, Oxford.

Millspaugh, J.J., Nielson, R.M., McDonald, L., Marzluff, J.M., Gitzen, R.A., Rittenhouse, C.D., Hubbard, M.W. \& Sheriff, S.L. 2006. Analysis of resource selection using utilization distributions. Journal of Wildlife Management 70, 384-395.

Morrison, D.W. \& Caccamise, D.F. 1990. Comparison of Roost Use by 3 Species of Communal Roostmates. Condor 92, 405-412.

Negro, J.J., Donázar, J.A. \& Hiraldo, F. 1993. Home range of lesser kestrels (Falco naumanni) during the breeding season, In Biology and conservation of small falcons. eds M.K. Nicholls, R. Clarke, pp. 144-150. The Hawk and Owl Trust, Canterbury, London.

Olea, P.P. 2001. Postfledging dispersal in the endangered Lesser Kestrel Falco naumanni. Bird Study 48, 110-115.

Olea, P.P., Vera, R., De Frutos, A. \& Robles, H. 2004. Premigratory communal roosts of the Lesser Kestrel in the boreal summer. Journal of Raptor Research 38, 278-282.

Ortego, J., Aparicio, J.M., Muñoz, A. \& Bonal, R. 2007. Malathion applied at standard rates reduces fledgling condition and adult male survival in a wild lesser kestrel population. Animal Conservation 10, 312-319.

Pagen, R.W., Thompson, F.R. \& Burhans, D.E. 2000. Breeding and post-breeding habitat use by forest migrant songbirds in the Missouri Ozarks. Condor 102, 738-747.

Penteriani, V., Delgado, M.M., Maggio, C., Aradis, A. \& Sergio, F. 2005. Development of chicks and predispersal behaviour of young in the Eagle Owl Bubo bubo. Ibis 147, 155-168.

Petit, D.R. 2000. Habitat use by landbirds along nearctic-neotropical migration routes: Implications for conservation of stopover habitats. Studies in Avian Biology 20, 15-33.

$R$ 2006. R: A language and environment for statistical computing. $R$ Foundation for Statistical Computing. R Development Core Team, Vienna, Austria. 
Downloaded on http://www.rproject.org.

Rappole, J.H. \& Ballard, K. 1987. Postbreeding Movements of Selected Species of Birds in Athens, Georgia. Wilson Bulletin 99, 475-480.

Rappole, J.H. \& Tipton, A.R. 1991. New Harness Design for Attachment of Radio Transmitters to Small Passerines. Journal of Field Ornithology 62, 335-337.

Reis, S. \& Rocha, P.N.A. 2001. Home-range, reproduction and habitat selection of radio-tagged lesser kestrel (Falco naumanni) in Mertola (Portugal), In Abstracts of the $4^{\text {th }}$ Eurasian Congress on Raptors. eds J. Bustamante, G. Crema, E. Casado, J. Seoane, C. Alonso, C. Rodríguez, M. de Lucas, G. Janss, p. 155. Estación Biológica de Doñana and Raptor Research Foundation, Sevilla, Spain.

Rivera, J.H.V., McShea, W.J., Rappole, J.H. \& Haas, C.A. 1999. Postbreeding movements and habitat use of adult wood thrushes in northern Virginia. Auk 116, 458-466.

Rivera, J.H.V., Rappole, J.H., McShea, W.J. \& Haas, C.A. 1998. Wood thrush postfledging movements and habitat use in northern Virginia. Condor 100, 69-78.

Rodríguez, C. 2004. Factores ambientales relacionados con el éxito reproductivo del cernícalo primilla. Cambio climático e intensificación agraria. $\mathrm{PhD}$ Thesis, University of Salamanca, Spain.

Samuel, M.D., Pierce, D.J. \& Garton, E.O. 1985. Identifying Areas of Concentrated Use Within the Home Range. Journal of Animal Ecology 54, 711-719.

Seaman, D.E., Griffith, B. \& Powell, R.A. 1998. KERNELHR: a program for estimating animal home ranges. Wildlife Society Bulletin 26, 95-100.

Sergio, F., Marchesi, L., Pedrini, P., Ferrer, M. \& Penteriani, V. 2004. Electrocution alters the distribution and density of a top predator, the eagle owl Bubo bubo. Journal of Applied Ecology 41, 836-845.

Siegfried, W.R. \& Skead, D.M. 1971. Status of the Lesser Kestrel in South Africa. Ostrich 42, 1-4.

Silverman, B.W. 1986. Density estimation for statistics and data analysis. Chapman and Hall, London.

Tejero, E., Soler, M., Camacho, I. \& Ávila, J.M. 1982. Contribución al conocimiento del régimen alimenticio del Cernícalo Primilla (Falco naumanni Fleish 1758). Boletín de la Estación Central de Ecología 22, 7782.

Tella, J.L. \& Forero, M.G. 2000. Farmland habitat selection of wintering lesser kestrels in a Spanish pseudosteppe: implications for conservation strategies. Biodiversity and Conservation 9, 433-441.

Tella, J.L., Forero, M.G., Hiraldo, F. \& Donázar, J.A. 1998. Conflicts between lesser Kestrel conservation and European agricultural policies as identified by habitat use analyses. Conservation Biology 12, 593-604.

Ursúa, E., Serrano, D. \& Tella, J.L. 2005. Does land irrigation actually reduce foraging habitat for breeding lesser kestrels? The role of crop types. 
Biological Conservation 122, 643-648.

Ursúa, E. \& Tella, J.L. 2001. Unusual large communal roosts of Lesser Kestrel in two electric substations of Northern Spain: implications for the conservation of Spanish population, In Abstracts of the $4^{\text {th }}$ Eurasian Congress on Raptors. eds J. Bustamante, G. Crema, E. Casado, J. Seoane, C. Alonso, C. Rodríguez, M. de Lucas, G. Janss, p. 188. Estación Biológica de Doñana and Raptor Research Foundation, Sevilla, Spain.

Van Winkle, W. 1975. Comparison of Several Probabilistic Home-Range Models. Journal of Wildlife Management 39, 118-123.

Vlachos, C., Bakaloudis, D., Chatzinikos, E., Papadopoulos, T. \& Tsalagas, D. 2003. Aerial hunting behaviour of the Lesser Kestrel Falco naumanni during the breeding season in Thessaly (Greece). Acta Ornithologica 38, 129-134.

Worton, B.J. 1989. Kernel methods for estimating the utilization distribution in home-range studies. Ecology 70, 164-168. 


\section{Capítulo 2.3}

\section{El papel del barbecho en el uso del}

hábitat por el Cernícalo Primilla durante el periodo premigratorio: implicaciones en la conservación de la abolición del barbecho obligatorio

The role of fallow in habitat use by the Lesser kestrel during the postfledging period: conservation implications of the abolition of obligatory setaside. De Frutos, A., Olea, P.P. Mateo-Tomás, P. \& Purroy, F.J. Submitted to European Journal of Wildlife Research. 


\section{Resumen}

Se ha demostrado que los barbechos mitigan la pérdida de biodiversidad agrícola, causada por la intensificación agrícola. Los barbechos son implementados principalmente por los programas de "retirada obligatoria" y de "barbecho voluntario". Sin embargo, la medida de "retirada obligatoria de tierras" ha sido recientemente eliminada por la "Health Check" de la PAC (Política Agraria Comunitaria). En este estudio, se examina el papel del barbecho en el uso del hábitat por un ave esteparia amenazada (el Cernícalo Primilla) durante el verano en el noroeste de España. Se analizó la presencia de la especie usando modelos lineales generalizados (GLM). El mejor modelo, basado en el AIC, que explicó la presencia de Cenícalo Primilla demostró que el hábitat más importante fue el barbecho y, en menor medida, el rastrojo de cereal de secano y el lindero. En contraste, los cultivos de regadío influyeron negativamente en la presencia de primillas. La heterogeneidad del mosaico de cultivos no fue importante para explicar la presencia de la especie. Los barbechos, al igual que los rastrojos de cereal de secano y los linderos, parecen ser idóneos para la alimentación debido a la abundancia de presas y a la baja cobertura vegetal. La abolición de la "retirada obligatoria de tierras" puede reducir la superficie total de barbecho (aprox. un 40.9\%), afectando posiblemente al uso de hábitat por parte del Cernícalo Primilla a través de un incremento de cultivos "no preferidos" (por ejemplo, cultivos de regadío) o mediante una reducción de alimento. La conservación del Cernícalo Primilla en las áreas premigratorias pasa por promover en ellas las ayudas agroambientales que fomentan el mantenimiento del sistema cerealista tradicional de secano caracterizado por un mosaico de cultivos con parches de hábitat semi-natural. 


\begin{abstract}
Fallows have been showed to correct loss of farmland biodiversity, caused by agricultural intensification. They are mainly introduced as part of both obligatory and voluntary set-aside schemes. However, the obligatory set-aside has recently been abolished by the Common Agricultural Policy (CAP) Health Check. In this study, we examine the role of fallow in fine-grained habitat use by a threatened farmland bird (Lesser kestrel) during summer in north-western Spain. To analyze lesser kestrel occurrence, we used generalized linear models (GLM), a theoreticinformation approach and a hierarchical partitioning (HP) analysis. The best AIC-based models explaining occurrence of Lesser kestrels showed that fallow was the more important habitat type and, to a lesser extent, dry cereal stubble and field margin. In contrast, irrigated crops negatively influenced occurrence. Heterogeneity of crop mosaic was not important in explaining occurrence of Lesser kestrel. Fallows, like dry cereal stubbles and field margins, seem to be suitable for foraging because of the high food resources and short vegetation cover. The abolition of the obligatory set-aside could reduce the total surface of fallow land (approx. 40.9\%), likely affecting habitat use by lesser kestrel through an increase of other non-preferred crops (e.g. irrigated crops) or by decreasing food resources. Agri-environment schemes focusing on the maintenance of low-intensive farming system with a mosaic of crops and semi-natural habitats interspersed should be promoted in premigratory areas to maintain Lesser kestrel.
\end{abstract}

Keywords: Obligatory set-aside, Fallow, Health Check, Falco naumanni, Post-fledging period, Habitat selection 



\section{Introduction}

The loss of biodiversity in the European farmlands during the last decades is well documented (Krebs et al. 1999; Donald et al. 2001; see review of Benton et al. 2003). Erosion of biodiversity is mainly consequence of the agricultural intensification (Donald et al. 2001), which is promoted by the Common Agricultural Policy (CAP). The increased agricultural intensity has produced profound changes in farming practices such as the crop homogenization, simplified rotations and removal of semi-natural habitats, such as fallows (Petit and Firbank 2006). In order to minimize the environmental impact of intensive agriculture, voluntary agrienvironmental schemes were introduced (Kleijn and Sutherland 2003). Some of these measures, such the voluntary set-aside, target on protecting biodiversity and restoring landscape (Kleijn and Sutherland 2003). Additionally, some agriculture obligations, such as the compulsory set-aside (European Commission 2003), have been showed to correct loss of biodiversity (review of Van Buskirk and Willi 2004; MacDonald et al. 2007). The compulsory set-aside obligated to farmers to leave 10 percent of their cultivated land as fallow each year to reduce agricultural surpluses (Buckingham et al. 1999). However, the CAP Health Check has recently approved the abolition of this obligatory set-aside in respond to both the current high cereal prices and the low cereal yields (European Commission 2009). This abolition is thus expected to reduce the surface of fallow land. Fallows as well as the field margins have demonstrated to be reservoirs of farmland biodiversity (Wilson et al. 1999; Marshall and Moonen 2002; Duelli and Obrist 2003). These semi-natural habitats increase also farmland heterogeneity, which have a key role in maintaining biodiversity in agricultural landscapes (Benton et al. 2003). In order to correctly establish recommendations of changing agricultural management practices in conservation is essential to know how these practices affect farmland biodiversity.

The detailed knowledge of a species' habitat needs is essential in developing effective habitat management strategies, especially for species of high conservation concern such as the Lesser kestrel (Falco 
naumanni) in Europe (BirdLife International 2009), considered as a potential flagship species for the farmland biodiversity (Biber 1996; Rodríguez and Wiegand 2009). Numerous studies on habitat use in migratory farmland birds have showed that fallow is an important habitat during the breeding and winter seasons (e.g. Delgado and Moreira 2000; Silva et al. 2004; Wretenberg et al. 2007). If fallow is also important during the post-fledging period is not known. The post-fledging period, which ranges from fledging to departure on fall migration (e.g. Rivera et al. 1998), is considered to be important for migratory birds due to they must build up fat reserves (Rivera et al. 1999) and moult (at less partly; see Rivera et al. 1998) prior the fall migration. In a study carried out by De Frutos and Olea (2008), lesser kestrel did not selected fallow at both home-range and core-area extents (346.8 ha and 92.7 ha, respectively). However, lesser kestrel may look at a smaller spatial extent, as shown in other bird species (Johnson 1980; Aebischer et al. 1993). Knowing the role of fallow at a finer scale can be relevant to predict both the effects of the imminent abolition of the compulsory set-aside and to plan efficiently management practices for conservation of Lesser kestrel, and of farmland biodiversity in general.

In this study, we aimed to examine the role of fallow in habitat use by Lesser kestrel during the post-fledging period at a fine scale in a extensive farmed area. Also we assessed heterogeneity of crop mosaic and identified which elements of fine-grained habitat (i.e., types of crops) of the crop mosaic are significant for habitat management strategies designed to maintain viable populations of Lesser kestrels during the postfledging period.

\section{Material and Methods}

\section{Study area}

The study was carried out in a $1,200 \mathrm{~km}^{2}$ area in the province of León, NW Spain (centred at $5^{\circ} 15^{\prime} \mathrm{W} 42^{\circ} 21^{\prime} \mathrm{N}$; annual average temperature: 11.7 ${ }^{\circ} \mathrm{C}$ and mean annual rainfall: 486mm; see details in De Frutos et al. 2007). The landscape is mainly flat and open, with scarce natural vegetation. The area is broken up by a number of small seasonal streams flowing northsouth; here are located most semi-natural grassland and poplar groves. 
Deciduous-mixed forests are scarce and scattered. The habitat consists mainly on extensive farmland (81.7\% of the study area surface), in rotation every other year. Dry cereals $(50.4 \%$ of the farmland surface) and ploughed fallow (30.8\%) constituted the main crops. We carried out the study when almost all the cereal cultures had been harvested $(99.9 \%$ of the dry cereal surface), remaining as stubbles and being exploited by a low grazing intensity while ploughed fields had not been sown yet. At a lesser extent, the leguminous crops (bean, lupine, pea and dry alfalfa; $8.4 \%$ of the farmland surface), non-ploughed fallow (5.3\%), irrigated crops (maize, beet, horticulture and irrigated alfalfa; $2.8 \%$ ), vineyard (1.5\%) and sunflower $(0.8 \%)$ were present in the study area.

In 2002, when this study was done, 23 breeding pairs of Lesser kestrel were documented in the study area (De Frutos and Olea 2008). During summer (July to September) this area holds yet a large postbreeding Lesser kestrel population, close to 1,000 individuals (Olea et al. 2004), which gathers in communal roosts from where they disperse daily to forage (De Frutos and Olea 2008).

\section{Data collection}

Lesser kestrel observations were obtained by surveys carried out between $11^{\text {th }}$ August and $7^{\text {th }}$ September of 2002 when Lesser kestrel abundance in the area peaked (i.e., between $15^{\text {th }}$ August and $15^{\text {th }}$ September; see Olea et al. 2004). Survey routes of $350 \mathrm{~km}$ in total $(n=16$ routes adequately distributed through the study area, see De Frutos et al. 2007) were covered in car at a low speed (approx. $20 \mathrm{~km} / \mathrm{h}$ ) for censusing kestrels. Censuses by car have been considered as a reliable method to count raptors at least in open landscape (Viñuela 1997). We counted Lesser kestrels localized within a strip $250 \mathrm{~m}$ wide at each side of the itinerary (see De Frutos et al. 2007) using binoculars and spotting scope. Windy and rainy conditions were avoided for censusing. For each Lesser kestrel registration, we recorded $x$-y coordinates, time of detection, habitat type and bird activity (Table 1). To avoid circadian rhythms of activity, kestrels were surveyed during all day (Tella et al. 1998) since kestrels are active throughout the day (see Donázar et al. 1993; Parr et al. 1997; Tella et al. 1998; Vlachos et al. 2003). To avoid counting Lesser kestrel associated with roosting, we did not census during $2 \mathrm{~h}$ after sunrise and $2 \mathrm{~h}$ before sunset (see Olea et al. 2004). 
Table 1. Habitat characteristics used for analyzing the role of fallows in habitat use by Lesser kestrel in a Spanish extensive farmland during the post-breeding period. These variables were measured within plots of 50,150 and 250 meters of radius centered on lesser kestrel and random locations.

\begin{tabular}{|c|c|}
\hline Variable & Definition \\
\hline \multicolumn{2}{|l|}{ Habitat cover: } \\
\hline Field margin & Surface in \% of field margins \\
\hline \multicolumn{2}{|l|}{ Crop type: } \\
\hline Dry cereal stubble & Surface in \% of dry cereal stubbles \\
\hline Ploughed fallow & Surface in \% of ploughed fallows \\
\hline Fallow & Surface in \% of non-ploughed fallows \\
\hline Leguminous crop & Surface in \% of leguminous crops \\
\hline Irrigated crop & Surface in \% of irrigated crops \\
\hline \multicolumn{2}{|l|}{ Heterogeneity of crop mosaics: } \\
\hline Habitat edge density (Edge) & $\begin{array}{l}\text { Total edge length in } \mathrm{m} \text { of all crop types including field } \\
\text { margins per } \mathrm{km}^{2}\end{array}$ \\
\hline $\begin{array}{l}\text { Landscape heterogeneity of } \\
\text { crops (Cropheter) }\end{array}$ & Crop habitat diversity using Shannon’s diversity index \\
\hline Richness & Number of different types of crops \\
\hline $\begin{array}{l}\text { Distance to the nearest colony } \\
\text { (Dcolony10) }\end{array}$ & $\begin{array}{l}\text { Distance in } m \text { to the nearest colony with more than } 10 \\
\text { breeding pairs from the centre of each grid square }\end{array}$ \\
\hline $\begin{array}{l}\text { Distance to the nearest roost } \\
\text { (Droost) }\end{array}$ & $\begin{array}{l}\text { Distance in } m \text { to the nearest roost from the centre of each } \\
\text { grid square }\end{array}$ \\
\hline Electrical wires (Wire) & Total length in $\mathrm{m}$ of electrical wires \\
\hline
\end{tabular}

\section{Data analysis}

To analyze the habitat use, we used a "use versus available" approach (see advantages in Klar et al. 2008). Firstly, we generated two sets of points (i.e., use and available). Use locations corresponded to Lesser kestrels detected during the surveys (see above; $n=127$ ). As a sample of availability, we randomly distributed as many additional points (i.e., the available locations; $n=127$ ) as use locations within a strip $250 \mathrm{~m}$ wide at each side of the survey routes. The available locations did not overlap with the use locations. Because we aimed to look at the spatial extent at which environmental variables better explained selection by Lesser kestrel, each use and available location was buffered with 50, 150 and $250 \mathrm{~m}$-radii. Thus, habitat predictor variables were measured within these buffers using ARCGIS 9.2 (Environmental Systems Research 
Institute Inc.). Given that De Frutos and Olea (2008) found that the landscape-scale habitat covers of farmland was far the most important habitat for foraging Lesser Kestrel during summer in this study area, we only focused on fine-grained habitat covers within farmland, including fallows and field margins. For this, we measured the more frequent crop types (dry cereal stubbles, leguminous crops and irrigated crops), field margins (strips with grass vegetation separating fields from roads, but almost non-existent between fields; Table 1) and fallows. These habitat covers were measured as the relative proportions of each habitat within the buffers from a digital land-use layer obtained from georeferenced aerial photographs $(0.7 \mathrm{~m}$ pixel resolution), which were validated by field observations. In our study area fallows resulted from the voluntary and the obligatory set-asides (Table 1) and they were grouped. The identification in situ of each type of set-aside was not clear; and access to the official data at the municipal scale was unavailable due to their confidentiality. Therefore, instead of classifying fallows according to the set-aside types, we assigned them to one of the following cover classes according to the vegetation cover: ploughed fallow (recently ploughed fields without a significant herbaceous vegetation cover) and fallow (old fallow over 1year; Table 1). Three variables quantifying heterogeneity of crop mosaics were calculated: two variables relating to the crop heterogeneities (Cropheter: habitat diversity of crop types using Shannon's diversity index; Heikkinen et al. 2004; Richness: number of different types of crops; Table 1 ); and one relating to the habitat edge densities (Edge; total edge length of all crop types including field margins per $\mathrm{km}^{2}$; Heikkinen et al. 2004; Table 1). Kestrels may select perches as look-out posts (Aparicio 1990; personal observations), so total length of electrical wires (Wire, see Table 1) within each buffer was also considered as an explanatory variable. It was measured from a digital cartographic map and validated by field observations. Since distribution of both breeding colonies and communal roosts of Lesser kestrel influences its abundance within the study area (see De Frutos et al. 2007), breeding colonies and communal roosts within and outside the study area were mapped. Based on this information, we generated two raster layers: "distance to the nearest roost" (Droots) and "distance to the nearest colony with more than 10 breeding pairs" (Dcolony10) both calculated from the centre of each buffer (Table 1). 
Statistical analysis

First, we used the Spearman's rank correlation to explore the correlations between the variables measured at each spatial extent (Table 1 , Table $\mathrm{S} 1$ in supplementary material). The highly correlated variables $\left(\left|r_{s}\right|>0.5\right)$ were included separately in the models (i.e., they were not put together in the same model) in the multivariate regression analyses (Table 2 ). The models were performed to identify the environmental variables that influenced presence of Lesser kestrel and the spatial extent at which were selected. We modelled the presence of Lesser kestrel as a function of the explanatory variables at each spatial extent using GLM with a logistic link function and a binomial error distribution. We performed all possible model permutations of the explanatory variables for each spatial extension. Resultant models for each spatial extent were ranked altogether using the AICc and the Akaike weight of each model $\left(\omega_{\mathrm{m}}\right)$ (Olea 2009), estimated following Burnham and Anderson (2002). Akaike weight is the relative likelihood of that model being the Kullback-Leibler best model within a set of $n$ models, with $\omega_{m}>0.9$ indicating a high level of support for a given model. We constructed a $95 \%$ confidence set of models by starting with the highest Akaike weight and adding the model with the next highest weight until the cumulative sum of weights exceeded 0.95 (Burnham and Anderson 2002). A model filtering procedure was then applied by removing the more complex models that did not have an AICvalue which was lower than all the simpler models within which they were nested (i.e. the same model with at least one additional variable; Richards 2008). The filtered models for each spatial extent were pulled together and ranked according to their AICC values. To know the relative contribution of each variable we calculated their Akaike weights. The Akaike weight for each variable $\left(\omega_{\mathrm{i}}\right)$ was calculated by summing, from the set of models within the $95 \%$ probability, the weights of those containing the variable, with the variables with the highest weight $\left(\sum \omega_{m}\right)$ being more important relative to the others. Additionally, we examined models with non-linear variables (second-order polynomial), which were no better than those with linear variables, so only linear variables were considered.

We also checked the assumption of independent errors by examining Moran's correlograms of residuals of the best models (see De Frutos et al. 2007). Correlograms plot the Moran's Index (I) coefficients against distances between localities (Legendre and Fortin 1989). This index indicates the degree of similarity/dissimilarity between the values of the 
residuals in this case. Distance classes for the correlogram were defined maximizing the similarity in the number of interactions between pairs of localities (Diniz et al. 2003). To test the significance of these Moran's coefficients for each lag distance, 9999 Monte Carlo permutations of the model residuals were performed and its $P$-values were calculated (Heikkinen et al. 2004). The Moran's correlogram as a whole is considered significant if at least one of its coefficients is significant at the probability level after progressive Bonferroni correction (here $\mathrm{P} \leq 0.01$ ). The distance classes, Moran's I statistics and correlograms were computed using the freeware package SAM (Spatial Analysis in Macroecology; Rangel et al. 2006).

Additionally, a hierarchical partitioning analysis (HP; Mac Nally 2002) was also performed using the explanatory variables included in the best AIC-based models (95\% confidence, see above) explaining occurrence of Lesser kestrels. This HP procedure calculates the independent contribution that each explanatory variable has on the response variable and separates it from the conjoint contribution, resulting from correlation with other variables. The method of fitting the model to data was by least squares (i.e., the goodness-of-fit measures were calculated by $\mathrm{R}^{2}$; Walsh and Mac Nally 2004).

All the modelling analyses were run in the $R$ statistical software $(R$ Version 2.6.2; The R Foundation for Statistical Computing, 2008) using the "hier.part" package (Walsh and Mac Nally 2004).

\section{Results}

The best AIC-based models ( $\Sigma \omega_{m}=95 \%$ confidence) explaining occurrence of Lesser kestrels were performed at the $50 \mathrm{~m}$-radius spatial extent (Table 2). These best models included together 7 variables, appearing three variables (Droost, Dcolony 10 and Wire) in all of them (i.e., $\omega_{i}=1$, Fig. 1a, Table 2). Wire was the most important variable explaining occurrence of Lesser kestrel $(70.7 \%$ of independent explained variability according to the HP results, Fig. 1b), which positively influenced occurrence. It increased in areas near to the breeding colony $(15.0 \%$ of independent explained variability, Fig. $1 \mathrm{~b})$ and to the roost $(14.3 \%)$. 
Fallow and Dry cereal stubble positively influenced occurrence and had a moderate-high relative contribution to the models $\left(\omega_{i}=0.8\right.$ and $8.2 \%$ of independent explained variability for Fallow; and $\omega_{i}=0.6$ and $4.2 \%$ for Dry cereal stubble).

Table 2. Ranking of the best models $\left(\Sigma \omega_{m}=95 \%\right)$ explaining occurrence of Lesser kestrels according to their AICc values after applying the filtering procedure; $\omega_{\mathrm{m}}$ : Akaike weight of each model. Note: bolder variables influenced negatively in the occurrence of Lesser kestrel.

\begin{tabular}{lcccc}
\hline Models & $\begin{array}{c}\text { Spatial } \\
\text { extent }\end{array}$ & AICc & $\omega_{\mathrm{m}}$ & Ranking \\
\hline Droost+Dcolony10+Wire+Field margin+Dry cereal stubble+Fallow & 50 & 0.00 & 0.324 & 1 \\
Droost+Dcolony10+Wire+Dry cereal stubble+Irrigated crop+Fallow & 50 & 0.78 & 0.219 & 2 \\
Droost+Dcolony10+Wire+Dry cereal stubble+Fallow & 50 & 0.82 & 0.215 & 3 \\
Droost+Dcolony10+Wire+Irrigated crop+Fallow & 50 & 2.81 & 0.079 & 4 \\
Droost+Dcolony10+Wire+Field margin+Fallow & 50 & 4.05 & 0.043 & 5 \\
Droost+Dcolony10+Wire+Fallow & 50 & 4.06 & 0.043 & 6 \\
Droost+Dcolony10+Wire+Field margin+Dry cereal stubble & 50 & 5.71 & 0.019 & 7 \\
Droost+Dcolony10+Wire+Dry cereal stubble+Irrigated crop & 50 & 5.95 & 0.017 & 8 \\
\hline
\end{tabular}

Field margin (3.6\% of independent explained variability) and Irrigated crop $(2.8 \%)$ had a lesser relative importance $\left(\omega_{i}=0.37\right.$ in both cases). Irrigated crop negatively influenced occurrence.

Results of the hierarchical partitioning (Fig. 1b) were consistent with the relative contributions from the best AIC-based models $\left(\Sigma \omega_{m}=95 \%\right.$ confidence; Fig. 1a).

Among the habitat variables, Fallow was the best predictor to explain occurrence, being significantly more abundant in areas used by Lesser kestrels (Fig. 1a, 1b, 2; ANOVA test; $F=4.07 ; P=0.048$ ).

Residuals from the best AIC-based models (95\% confidence; $n=8$ models; Table 2) did not show a significant spatial pattern (Figure S1 in supplementary material). 
(a)

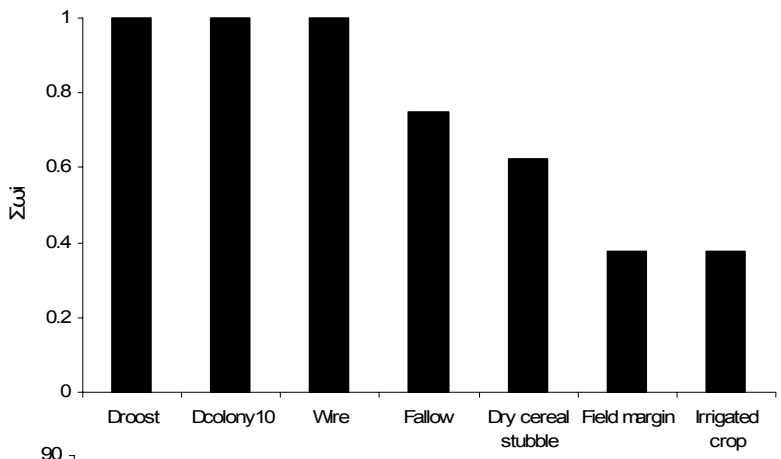

(b)

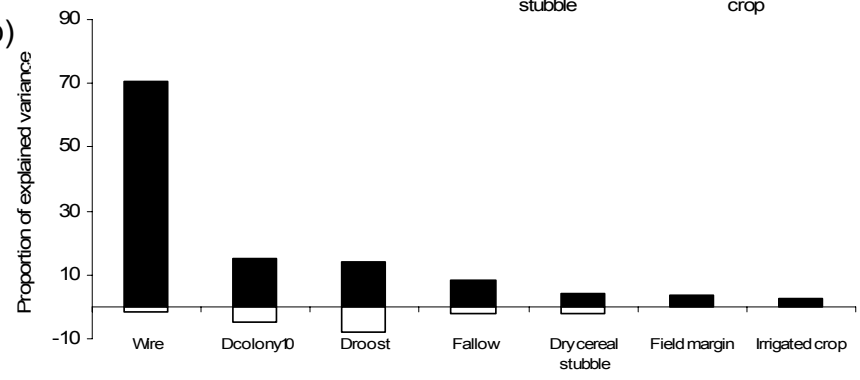

Figure 1. (a) Relative contribution of each variable in the best models $\left(\Sigma \omega_{m}=95 \%\right)$ explaining occurrence of Lesser kestrels (see Table 2) according to the sum of its Akaike weights $\left(\Sigma \omega_{i}\right)$. Note: Droost, Dcolony10 and Irrigated crop influenced negatively in the occurrence of Lesser kestrel. (b) Results of the hierarchical partitioning analysis. Percentage of independent and joint contribution to the total explanatory power of each variable included in the best AIC-based models ( $\Sigma \omega m=95 \%$ confidence; $n=8$ models; see Table 2) explaining occurrence of Lesser kestrels in a $384 \mathrm{~km}^{2}$ Spanish farmland during summer of 2002. Note that negative joint contribution of one variable in HP indicates that the other variables act as suppressor on the particular variable.

\section{Discussion}

This study revealed that fallow, dry cereal stubble and field margin positively influenced on the occurrence of Lesser kestrel during the postfledging period, with fallow being the habitat type more important. In contrast, irrigated crops influenced negatively the occurrence of Lesser kestrel. Like previously documented (De Frutos et al. 2007; De Frutos and Olea 2008), occurrence of Lesser kestrel diminished with the distance to both the nearest roost and the breeding colony. The positive association 
between occurrence of Lesser kestrel and wires, which was the best predictor, is concordant with that observed by De Frutos et al. (2007). Lesser kestrels are easier detectable when perching than when standing on the ground. Alternatively, these human structures are also quite used as look-out posts (Aparicio 1990; authors, unpubl. data), suggesting to be an important factor determining the foraging Lesser kestrel distribution during summer.

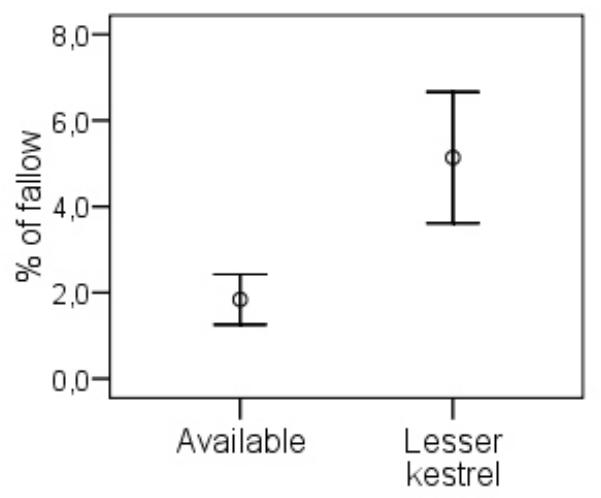

Figure 2. Means $( \pm 1 \mathrm{SE})$ of percentage of fallow in the available and used plots by lesser kestrel at the $50 \mathrm{~m}$-radius spatial extent.

Results demonstrate the importance of the low-intensity farming system, which allows the coexistence of crop fields with patches of seminatural habitats such as fallows and field margins. There was no significant effect of the variables used to measure heterogeneity of crop mosaic in our models. This suggests that lesser kestrel occurrence depend more on the abundance and distribution of particular habitats that habitat heterogeneity per se, as has been suggested for other farmland bird species (Heikkinen et al. 2004; Brambilla et al. 2008).

The positive effect of fallow on Lesser kestrels occurrence might be related to the food resources, which might be also the case for dry cereal stubble and field margin. Arthropod species, mainly Orthoptera, are known to be the main part of Lesser kestrel's diet during the post-fledging period (Franco and Andrada 1977; Tejero et al. 1982; authors unpublished data). Many studies have showed that higher diversity and 
abundance of arthropods are associated with these habitats in the farmed landscape not only during summer (e.g. Tellería 1988; Henderson et al. 2000a) but also during other seasons (e.g. breeding season, Rodríguez et al. 2006; Traba et al. 2008). Moreover, these habitats presumably are suitable for foraging because they have short vegetation (Henderson et al. 2000 b; Rodríguez et al. 2006, authors, unpubl. data) providing good prey accessibility (Rodríguez et al. 2006, authors, unpubl. data) and hunting areas (unpublished data). De Frutos and Olea (2008) found that these habitats were not selected by summering Lesser kestrels at both home range and core-area scale. Here, we studied habitat use by lesser kestrel at a smaller scale (50m-radius plot), i.e. a small percentage (namely, $1 \%$ ) of the surface covered by the core area of Lesser kestrel. This suggests that habitat requirements can vary between different spatial scales, agreeing to Johnson (1980).

In our study area, part of fallow land has been encouraged by agrienvironmental schemes oriented to enhance biodiversity conservation, especially farmland birds (see Llusía and Oñate 2004, pers. obs.). However, the total surface of fallow land is expected to be reduced (approx. 40.9\%, see European Commission 2009; Vanni 2009) due to the recent abolition of the obligatory set-aside. The consequences of this abolition are not clear at all, but it could increase the surface of arable land by sowing the fallows (i.e., both ploughed and non-ploughed fallows). Surface values of other crop types, non-used by lesser kestrel, might also increase (e.g. increase of the surface of irrigated crops, see below). In addition, a reduction of non-ploughed fallow could also has an indirect effect on lesser kestrel through a decrease in food source such as Orthoptera (main resource in summer, see above, unpublished data), whose highly mobile species can disperse from fallow to other crops (e.g. dry cereal stubble; see Douglas et al. 2009), like a source-sink system. Fallow has been proved to be a preferred habitat for foraging in other farmland birds during summer (Henderson et al. 2000a; Henderson et al. 2000b), including many endangered species [e.g. Great bustard Otis Tarda (Moreira et al. 2004), Little bustard Tetrax tetrax and Black bellied sandgrouse Pterocles orientalis (Delgado and Moreira 2000)]. Fallow is a particularly important habitat for farmland birds and, according to other studies, for other taxonomic groups (e.g., weed seeds, plants and invertebrates; see Henderson et al. 2000a; Henderson et al. 2000b; Van 
Buskirk and Willi 2004; Traba et al. 2008), acting like reservoirs of farmland biodiversity.

The negative effect of irrigated crops on occurrence of Lesser kestrel during summer agrees with that observed with De Frutos and Olea (2008), which suggested that the avoidance of these crops by Lesser kestrel may be related with the low availability and accessibility of preys for the aerial hunting Lesser kestrels. In our study area irrigated crops are characterized by dense and tall vegetation and higher pesticides inputs (Tejedo et al. 2008), being maize the main irrigated crop type (approx. $90 \%$ ). Our study area will be inevitably transformed into irrigated crops (up to $40-52 \%$ of the surface of the study area), involving a field enlargement, in detriment of field margins, and a crop homogenization. This increased irrigated surface is likely to affect negatively to Lesser kestrel occurrence in the study area. Therefore, agri-environment schemes focusing on the maintenance of low-intensive farming system with a mosaic of crops, particularly with dry cereal fields, and semi-natural habitats interspersed are, a priori, expected to maintain Lesser kestrel persistence and thus farmland biodiversity in general (Stoate and Parish 2001; Tilman et al. 2001; Benton et al. 2003; Green et al. 2005). In our study area Lesser kestrels used areas formed by a mosaic of habitats dominated by dry cereal stubbles ( $54.8 \%$ relative to the surface covered by the $50 \mathrm{~m}$-radius plot), followed by non-ploughed fallows (5.1\%) and field margins (3.4\%). Currently, compensation payments for conservation measures are on a voluntary basis, and they should be highly prioritized in premigratory areas, where Lesser kestrel survival may be highly dependent on how these areas are managed. This issue can be particularly relevant in summer during which a significant fraction of the Spanish Lesser kestrel population can gather in only a few roost sites (see Ursúa and Tella 2001; Olea et al. 2004). Therefore, the persistence of fallow around communal roosts in premigratory areas of Lesser kestrel should be promoted.

\section{Acknowledgments}

We are grateful to Olga Mora, Hugo Robles, Enrique Osorio and Rubén Vera for their help during the fieldwork. The georeferenced aerial photographs were provided by the Junta de Castilla y León. This research 
was partially supported by Monteleón-Caja España Foundation, University of León (project ULE 2005-08), Junta de Castilla y León (project SEK02B06) and Ministerio de Educación y Ciencia (project CGL200605047/BOS). A.F. was financed by FPU predoctoral fellowship of the University of León. P.M.T. was supported by a PhD scholarship funded by the Spanish Ministerio de Educación y Ciencia.

\section{References}

Aebischer, N.J., Robertson, P.A. \& Kenward, R.E. 1993. Compositional Analysis of Habitat Use from Animal Radio-Tracking Data. Ecology 74, 1313-1325.

Aparicio, J.M. 1990. Actividad, selección del método de caza y balance energético diario de Falco naumanni durante el periodo premigratorio. Ardeola 37, 163-178.

Benton, T.G., Vickery, J.A. \& Wilson, J.D. 2003. Farmland biodiversity: is habitat heterogeneity the key? Trends in Ecology \& Evolution 18, 182-188.

Biber, J.P. 1996. International Action Plan for the Lesser Kestrel (Falco naumanni). Cambridge. UK.

BirdLife International 2009. Falco naumanni, In 2009 IUCN Red List of Threatened Species. Available at http://www.redlist.org. Accessed 03 Feb 2009. ed. IUCN.

Brambilla, M., Guidali, F. \& Negri, I. 2008. The importance of an agricultural mosaic for Cirl Buntings Emberiza cirlus in Italy. Ibis 150, 628-632.

Buckingham, D.L., Evans, A.D., Morris, A.J., Orsman, C.J. \& Yaxley, R. 1999. Use of set-aside land in winter by declining farmland bird species in the UK. Bird Study 46, 157-169.

Burnham, K.P. \& Anderson, D.R. 2002. Model selection and multimodel inference : a practical information-theoretic approach, 2nd edn. Springer, New York.

De Frutos, A. \& Olea, P.P. 2008. Importance of the premigratory areas for the conservation of lesser kestrel: space use and habitat selection during the post-fledging period. Animal Conservation 11, 224-233.

De Frutos, A., Olea, P.P. \& Vera, R. 2007. Analyzing and modelling spatial distribution of summering lesser kestrel: The role of spatial autocorrelation. Ecological Modelling 200, 33-44.

Delgado, A. \& Moreira, F. 2000. Bird assemblages of an Iberian cereal steppe. Agriculture Ecosystems \& Environment 78, 65-76.

Diniz, J.A.F., Bini, L.M. \& Hawkins, B.A. 2003. Spatial autocorrelation and red herrings in geographical ecology. Global Ecology and Biogeography 12, 5364. 
Donald, P.F., Green, R.E. \& Heath, M.F. 2001. Agricultural intensification and the collapse of Europe's farmland bird populations. Proceedings of the Royal Society of London Series B-Biological Sciences 268, 25-29.

Donázar, J.A., Negro, J.J. \& Hiraldo, F. 1993. Foraging habitat selection, land-use changes and population decline in the lesser kestrel Falco naumanni. Journal of Applied Ecology 30, 515-522.

Douglas, D.J.T., Vickery, J.A. \& Benton, T.G. 2009. Improving the value of field margins as foraging habitat for farmland birds. Journal of Applied Ecology 46, 353-362.

Duelli, P. \& Obrist, M.K. 2003. Regional biodiversity in an agricultural landscape: the contribution of seminatural habitat islands. Basic and Applied Ecology 4, 129-138.

European Commission 2009. Agriculture and Rural Development, In http://ec.europa.eu/agriculture/index_en.htm Downloaded on 02 Feb 2009.

Franco, A. \& Andrada, J.A. 1977. Alimentación y selección de presa en Falco naumanni. Ardeola 23, 137-187.

Green, R.E., Cornell, S.J., Scharlemann, J.P.W. \& Balmford, A. 2005. Farming and the fate of wild nature. Science $307,550-555$.

Heikkinen, R.K., Luoto, M., Virkkala, R. \& Rainio, K. 2004. Effects of habitat cover, landscape structure and spatial variables on the abundance of birds in an agricultural-forest mosaic. Journal of Applied Ecology 41, 824-835.

Henderson, I.G., Cooper, J., Fuller, R.J. \& Vickery, J. 2000a. The relative abundance of birds on set-aside and neighbouring fields in summer. Journal of Applied Ecology 37, 335-347.

Henderson, I.G., Vickery, J.A. \& Fuller, R.J. 2000b. Summer bird abundance and distribution on set-aside fields on intensive arable farms in England. Ecography 23, 50-59.

Johnson, D.H. 1980. The Comparison of Usage and Availability Measurements for Evaluating Resource Preference. Ecology 61, 65-71.

Klar, N., Fernandez, N., Kramer-Schadt, S., Herrmann, M., Trinzen, M., Buttner, I. \& Niemitz, C. 2008. Habitat selection models for European wildcat conservation. Biological Conservation 141, 308-319.

Kleijn, D. \& Sutherland, W.J. 2003. How effective are European agri-environment schemes in conserving and promoting biodiversity? Journal of Applied Ecology 40, 947-969.

Krebs, J.R., Wilson, J.D., Bradbury, R.B. \& Siriwardena, G.M. 1999. The second silent spring? Nature 400, 611-612.

Legendre, P. \& Fortin, M.J. 1989. Spatial Pattern and Ecological Analysis. Vegetatio 80, 107-138.

Llusía, D. \& Oñate, J.J. 2004. Are the conservation requirements of pseudosteppe birds adequately covered by Spanish agri-environmental schemes? An ex-ante assessment, In International Symposium on Ecology and Conservation of Steppe Land Birds. pp. 31-42. Sociedad Espanola 
Ornitolgia, Lleida, Spain.

Mac Nally, R. 2002. Multiple regression and inference in ecology and conservation biology: further comments on identifying important predictor variables. Biodiversity and Conservation 11, 1397-1401.

MacDonald, D.W., Tattersall, F.H., Service, K.M., Firbank, L.G. \& Feber, R.E. 2007. Mammals, agri-environment schemes and set-aside - what are the putative benefits? Mammal Review 37, 259-277.

Marshall, E.J.R. \& Moonen, A.C. 2002. Field margins in northern Europe: their functions and interactions with agriculture. Agriculture Ecosystems \& Environment 89, 5-21.

Moreira, F., Morgado, R. \& Arthur, S. 2004. Great bustard Otis tarda habitat selection in relation to agricultural use in southern Portugal. Wildlife Biology 10, 251-260.

Olea, P. 2009. Analysing spatial and temporal variation in colony size: an approach using autoregressive mixed models and information theory. Population Ecology 51, 161-174.

Olea, P.P., Vera, R., De Frutos, A. \& Robles, H. 2004. Premigratory communal roosts of the Lesser Kestrel in the boreal summer. Journal of Raptor Research 38, 278-282.

Parr, S.J., Naveso, M.A. \& Yarar, M. 1997. Habitat and potential prey surrounding lesser kestrel Falco naumanni colonies in central Turkey. Biological Conservation 79, 309-312.

Petit, S. \& Firbank, L. 2006. Predicting the risk of losing parcels of semi-natural habitat to intensive agriculture. Agriculture Ecosystems \& Environment 115, 277-280.

Rangel, T., Diniz-Filho, J.A.F. \& Bini, L.M. 2006. Towards an integrated computational tool for spatial analysis in macroecology and biogeography. Global Ecology and Biogeography 15, 321-327.

Richards, S.A. 2008. Dealing with overdispersed count data in applied ecology. Journal of Applied Ecology 45, 218-227.

Rivera, J.H.V., McShea, W.J., Rappole, J.H. \& Haas, C.A. 1999. Postbreeding movements and habitat use of adult wood thrushes in northern Virginia. Auk 116, 458-466.

Rivera, J.H.V., Rappole, J.H., McShea, W.J. \& Haas, C.A. 1998. Wood thrush postfledging movements and habitat use in northern Virginia. Condor 100, 69-78.

Rodríguez, C., Johst, K. \& Bustamante, J. 2006. How do crop types influence breeding success in lesser kestrels through prey quality and availability? A modelling approach. Journal of Applied Ecology 43, 587-597.

Rodríguez, C. \& Wiegand, K. 2009. Evaluating the trade-off between machinery efficiency and loss of biodiversity-friendly habitats in arable landscapes: The role of field size. Agriculture Ecosystems \& Environment 129, 361-366.

Silva, J.P., Pinto, M. \& Palmeirim, J.M. 2004. Managing landscapes for the little 
bustard Tetrax tetrax: lessons from the study of winter habitat selection. Biological Conservation 117, 521-528.

Stoate, C. \& Parish, D. 2001. Crops grown on set-aside land bring wild birds back to the fields - Monitoring is under way, and results so far are promising. Nature 414, 687-687.

Tejedo, P., Mateo-Tomás, P., De Frutos, A., Pouillard, E., Gómez, D., Barja, I., Sanz, M.J., Purroy, F.J. \& Olea, P.P. 2008. Impacto de la intensificación agraria sobre la biodiversidad. Implicaciones para una gestión agrícola sostenible., In Congreso Nacional del Medio Ambiente. Cumbre del Desarrollo Sostenible. Madrid. España.

Tejero, E., Soler, M., Camacho, I. \& Ávila, J.M. 1982. Contribución al conocimiento del régimen alimenticio del Cernícalo Primilla (Falco naumanni Fleish 1758). Boletín de la Estación Central de Ecología 22, 7782.

Tella, J.L., Forero, M.G., Hiraldo, F. \& Donázar, J.A. 1998. Conflicts between lesser Kestrel conservation and European agricultural policies as identified by habitat use analyses. Conservation Biology 12, 593-604.

Tellería, J.L. 1988. Avifauna de los campos de cereales del interior de España. Sociedad Española de Ornitología, Madrid, Spain.

Tilman, D., Fargione, J., Wolff, B., D'Antonio, C., Dobson, A., Howarth, R., Schindler, D., Schlesinger, W.H., Simberloff, D. \& Swackhamer, D. 2001. Forecasting agriculturally driven global environmental change. Science 292, 281-284.

Traba, J., Morales, M.B., de la Morena, E.L.G., Delgado, M.P. \& Kristin, A. 2008. Selection of breeding territory by little bustard (Tetrax tetrax) males in Central Spain: the role of arthropod availability. Ecological Research 23, 615-622.

Ursúa, E. \& Tella, J.L. 2001. Unusual large communal roosts of Lesser Kestrel in two electric substations of Northern Spain: implications for the conservation of Spanish population, In Abstracts of the $4^{\text {th }}$ Eurasian Congress on Raptors. eds J. Bustamante, G. Crema, E. Casado, J. Seoane, C. Alonso, C. Rodríguez, M. de Lucas, G. Janss, p. 188. Estación Biológica de Doñana and Raptor Research Foundation, Sevilla, Spain.

Van Buskirk, J. \& Willi, Y. 2004. Enhancement of farmland biodiversity within setaside land. Conservation Biology 18, 987-994.

Vanni, F. 2009. L'abolizione del set aside obbligatorio: le implicazioni ambientali e gli strumenti sostitutivi proposti nell'ambito dell'Health Check della PAC. Istituto Nazionale di Economia Agraria, Italia.

Viñuela, J. 1997. Road transects as a large-scale census method for raptors: The case of the Red Kite Milvus milvus in Spain. Bird Study 44, 155-165.

Vlachos, C., Bakaloudis, D., Chatzinikos, E., Papadopoulos, T. \& Tsalagas, D. 2003. Aerial hunting behaviour of the Lesser Kestrel Falco naumanni during the breeding season in Thessaly (Greece). Acta Ornithologica 38, 129-134.

Walsh, C. \& Mac Nally, R. 2004. "The hier.part Package" version 1.0. Hierarchical 
Partitioning. Documentation for $\mathrm{R}$ : A language and environment for statistical computing. $\mathrm{R}$ Foundation for statistical Computing, http://www.rproject.org.

Wilson, J.D., Morris, A.J., Arroyo, B.E., Clark, S.C. \& Bradbury, R.B. 1999. A review of the abundance and diversity of invertebrate and plant foods of granivorous birds in northern Europe in relation to agricultural change. Agriculture Ecosystems \& Environment 75, 13-30.

Wretenberg, J., Lindstrom, A., Svensson, S. \& Part, T. 2007. Linking agricultural policies to population trends of Swedish farmland birds in different agricultural regions. Journal of Applied Ecology 44, 933-941. 


\section{Supplementary material}

Table S1. Occurrence of variables highly correlated (Spearman's rank correlation coefficients larger than 0.5; i.e., $\left|r_{\mathrm{s}}\right|>0.5$ ) in each spatial extent.

\begin{tabular}{lcccc}
\hline \multirow{2}{*}{ Pairs of correlated variables } & \multicolumn{3}{c}{ Spatial extent } \\
\cline { 2 - 4 } & $50 \mathrm{~m}$ & $150 \mathrm{~m}$ & $250 \mathrm{~m}$ \\
\hline Dry cereal stubble vs. Ploughed fallow & $\mathrm{X}$ & $\mathrm{X}$ & $\mathrm{X}$ \\
Habitat edge density (Edge) vs. Field margin & $\mathrm{X}$ & $\mathrm{X}$ & \\
Edge vs. Landscape heterogeneity of crops (Cropheter) & $\mathrm{X}$ & & \\
Edge vs. Richness & $\mathrm{X}$ & & \\
Richness vs. Cropheter & $\mathrm{X}$ & $\mathrm{X}$ & $\mathrm{X}$ \\
Richness vs. Fallow & & $\mathrm{X}$ & $\mathrm{X}$ \\
\hline
\end{tabular}

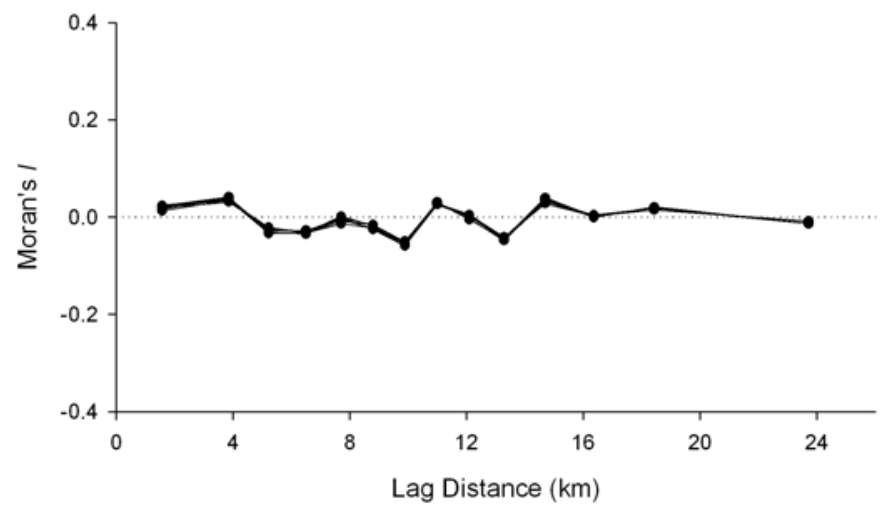

Figure S1. Spatial correlogram of Moran's / for residuals from the best AIC-based models (95\% confidence; $n=8$ models; see Table 2 ) explaining occurrence of Lesser kestrels. All Moran's I values were insignificant at the probability level after sequential Bonferroni correction (here $P<0.01$ ). Note that the lines of the residuals of the 8 models are superimposed. 


\section{Capítulo 2.4}

Selección de hábitat de caza por el

Cernícalo Primilla Falco naumanni durante el periodo premigratorio

Hunting habitat selection by the Lesser kestrel during the post-fledging period. Manuscrito en preparación. 


\section{Resumen}

El Cernícalo Primilla (Falco naumanni) es una especie globalmente amenazada. El drástico declive poblacional de la especie en las últimas décadas se ha asociado principalmente con la pérdida del hábitat de alimentación, debido principalmente a la intensificación agraria. Sin embargo se desconoce los requerimientos de hábitat de alimentación durante el periodo premigratorio. En este estudio se examina la selección de hábitat de alimentación por el Cernícalo Primilla comparando lo disponible en el área con lo usado por los primillas para cazar durante el verano. Los valores del índice de Savage mostraron que los primillas seleccionaron positivamente las parcelas de rastrojo de cereal de secano y evitaron negativamente los barbechos arados, regadíos y pastizales. La reciente aprobación como zona regable proyectada en esta área de estudio puede afectar negativamente a las áreas de caza de la población de primillas estudiada. 


\section{Introducción}

El Cernícalo Primilla (Falco naumanni) está actualmente catalogado como especie amenazada a nivel mundial ("Vulnerable"; BirdLife International 2009). Sus poblaciones han sufrido un gran declive durante las últimas décadas. Algunos autores sugieren que la principal causa responsable de este declive es la pérdida de hábitat de alimentación, debido principalmente a la intensificación agrícola (Donázar et al. 1993; Tella et al. 1998; Atienza \& Tella 2004). Estas prácticas agrícolas modernas, promovidas por la PAC (Política Agraria Comunitaria), han supuesto cambios en la rotación de cultivos, transformación de cultivos de secano a regadío, una mayor homogeneidad paisajística, un mayor uso de biocidas y la eliminación de hábitat semi-naturales (linderos y barbechos) (Petit \& Firbank 2006), afectando todo ello a sus áreas de alimentación. Por otro lado, estos cambios agrícolas han implicado la reducción en la disponibilidad de alimento del Primilla (Donázar et al. 1993). Las principales áreas de alimentación se incluyen en un paisaje abierto, principalmente áreas agrícolas con cultivos extensivos, sobre todo de secano, dónde sus presas terrestres son abundantes y fáciles de cazar. Se alimenta básicamente de insectos, particularmente ortópteros, en especial saltamontes y grillos, y con menor frecuencia, sobre todo en la época reproductora, de ratones, topillos y lagartijas (Franco \& Andrada 1977; Heredia et al. 1996). El estudio de los requerimientos de hábitat de una especie a lo largo del ciclo anual permite comprender su biología e incrementar la eficacia de los programas de su gestión y conservación, garantizando así su supervivencia (Steenhof et al. 1984; Blanco \& Tella 1999). Existe mucha evidencia científica sobre la selección de hábitat de alimentación del Cernícalo Primilla durante el periodo de cría (Franco 1980; Donázar et al. 1993; Franco \& Sutherland 2004; García et al. 2006) y en menor medida durante el periodo invernal (Tella \& Forero 2000). Sin embargo esta información es desconocida para el periodo premigratorio. En este estudio se analiza la selección de hábitat usado para cazar por el Cernícalo Primilla en un área premigratoria durante dos veranos consecutivos (2001 y 2002). 


\section{Métodos}

Área de estudio

El área de estudio está situada al Sureste de la provincia de León a 800 m.s.n.m. (centrada geográficamente a $5^{\circ} 15^{\prime} \mathrm{W}$ y $42^{\circ} 21^{\prime} \mathrm{N}$ ). Abarca una extensión aproximada de $412 \mathrm{~km}^{2}$ y se corresponde prácticamente con el de los capítulos 2.1 y 2.3 de la presente tesis (ver detalles en los capítulos 2.1 y 2.3 ).

\section{Disponibilidad de hábitat de alimentación}

Para el análisis de la selección de hábitat de alimentación, fueron considerados únicamente aquellos usos del suelo potencialmente disponibles para la alimentación del Cernícalo Primilla (cereal sin segar, rastrojo de cereal, barbecho no arado, barbecho arado, leguminosas [guisantes, garbanzos y altramuz], girasol, viñedo, alfalfa de secano, regadío [maíz, alfalfa de regadío y hortofruticultura], eriales, pastizales, matorrales y linderos; ver tabla 1). Para cuantificar la disponibilidad de hábitat de alimentación, se midieron estos usos de suelo en todo el área de estudio usando 3 métodos diferentes:

a) para los usos de suelo de pastizal y matorral han sido calculadas sus proporciones con un planímetro digital sobre mapas de cultivo y aprovechamientos a escala 1:50.000, editados por el Ministerio de Agricultura de España

b) para obtener las proporciones de los linderos se ha usado un curvímetro para medir sus longitudes sobre mapas topográficos a escala 1:25.000. Para el cálculo de la superficie de los linderos se ha tomado como anchura $3,3 \mathrm{~m}$ (media=3,3; SD=1,3; $=94$ medidas aleatorias)

c) los tipos de cultivo han sido muestreados a través del índice kilométrico de abundancia (IKA), que indica la proporción del tipo de parcela por kilómetro de transecto recorrido. Para ello se realizaron medidas lineales con el coche a ambos lados del camino (Parr et al. 1997 ) usando un GPS, con una precisión $\pm 3 \mathrm{~m}$ (otros autores usan el cuentakilómetros del coche para medir las parcelas de cultivo, con una precisión $\pm 50 \mathrm{~m}$; Parr et al. 1997; Tella \& Forero 2000). A medida que se avanzaba con el coche, se registraban en una grabadora tanto el tipo de cultivo a ambos lados del camino como sus longitudes (medido con el GPS). Dado que el GPS mide sólo distancias lineales, se reiniciaba poniendo a cero éste al final de cada recta. 
Para determinar los IKAs de cultivos se recorrieron los mismos itinerarios del siguiente apartado.

Tabla 1. Variables de características del hábitat consideradas en el análisis de la selección de hábitat usado por el Cernícalo Primilla para cazar en un área agrícola extensivo de secano durante el periodo premigratorio. IKA: Índice Kilométrico de Abundancia.

\begin{tabular}{ll}
\hline Variable & Definición \\
\hline Linderos & Superficie de linderos en \% \\
Pastizal & Superficie de pastizal en \% \\
Matorral & Superficie de matorral en \% \\
Alfalfa & IKA de alfalfa \\
Barbecho arado & IKA de barbecho arado \\
Cereal sin segar & IKA de cereal sin segar \\
Erial & IKA de erial \\
Girasol & IKA de girasol \\
Leguminosas & IKA de leguminosas \\
Rastrojo de cereal & IKA de rastrojo de ceral \\
Regadío & IKA de regadío \\
Barbecho no arado & IKA de barbecho no arado \\
Viñedo & IKA de viñedo \\
\hline
\end{tabular}

Muestreo de cernícalos primillas cazando

En el año 2001 se recorrieron 37 itinerarios (609 km en total) entre la segunda quincena de agosto y la segunda quincena de septiembre; y en el año 2002, 8 itinerarios (193,2 km en total) realizados en la primera quincena de septiembre. Los recorridos se realizaron en coche a velocidad lenta y en días sin lluvia y sin fuerte viento. Los itinerarios se llevaron a cabo tanto por la mañana (dos horas después de la salida del sol) como por la tarde pero antes de las 19:00h (hora local), a partir de la cual los individuos se reúnen para acudir a los dormideros comunales (Olea 2001; Olea et al. 2004, obs. pers.).

Para el análisis de la selección de hábitat de alimentación, fueron considerados únicamente los individuos de Primilla que cazaban activamente (cernidos o cazas desde posaderos) detectados durante los recorridos en coche. El tipo de parcela donde cazaba cada individuo se registró en una grabadora. Se tomó una única observación para cada individuo con el fin de evitar sesgos por pseudo-replicación. No se 
consideraron los primillas que tenían otro tipo de conducta (vuelos direccionales o reposo; Tella \& Forero 2000).

Para la identificación de los primillas, se usaron prismáticos y telescopio 20-60x, ya que la diferencia entre especies (Vulgar $F$. tinnunculus y Primilla) no siempre es clara (Negro 1991; Hiraldo et al. 1995). Se realizaron numerosas paradas durante el recorrido del transecto para distinguir de forma fiable las 2 especies: Cernícalo Primilla y Cernícalo Vulgar.

Posteriormente, se calcularon las proporciones relativas de las observaciones de caza en cada tipo de hábitat usado (ver tabla 4) y las proporciones de los hábitats respecto a su disponibilidad (ver figuras 1 y 2).

\section{Análisis estadístico}

Para determinar si existe selección de hábitat usado, se utilizó el índice de Savage $w_{i}=U_{i} / p_{i}$, donde $U_{i}$ es la proporción de los individuos cazando registradas en cada tipo de hábitat y pi es la proporción de ese hábitat en el total de hábitat disponible. Este índice varía de 0 (máxima selección negativa) a infinito (máxima selección positiva). Para ver el significado estadístico del valor obtenido del índice de Savage se aplica el el estadístico $\left(w_{i}-1\right)^{2} /$ s.e. $\left(w_{i}\right)^{2}$ con el valor crítico de la prueba de Chicuadradado con un grado de libertad. Se consideró como significativo con una probabilidad de $p<0,05$. El valor 1 del índice de Savage indica que no existe selección, es decir, usan el hábitat en proporción a lo disponible, lo cual es considerado como hipótesis nula.

El error estándar del índice [s.e. $\left.\left(W_{i}\right)\right]$ se calcula a partir de la raíz cuadrada de $\left[\left(1-p_{i}\right) /\left(u_{+} \times p_{i}\right)\right]$, donde $u_{+}$es el número de observaciones registradas (Manly et al. 1993).

\section{Resultados}

Disponibilidad de hábitat de alimentación

Dentro del área cultivada $(86,6 \%$ de la superficie del área de estudio en el 2001 y $87,6 \%$ en el 2002), el rastrojo de cereal representa la mayor proporción (47,7\% en el 2001 y $48,8 \%$ en el 2002; Tabla 2). Las proporciones relativas para el resto de cultivos se indican en la tabla 2. 
Tabla 2. Proporciones relativas para cada uso del suelo respecto al área cultivada en los años 2001 y 2002.

\begin{tabular}{lrr}
\hline \multirow{2}{*}{ Tipos de cultivo } & \multicolumn{2}{c}{$\%$ relativa } \\
\cline { 2 - 3 } & año 2001 año 2002 \\
\hline lindero & 2,0 & 1,6 \\
pastizal & 0,2 & 0,03 \\
matorral & 0,2 & 0,03 \\
rastrojo de cereal & 47,7 & 48,8 \\
barbecho arado & 33,3 & 31,5 \\
regadío & 2,4 & 5,0 \\
barbecho no arado & 3,0 & 4,9 \\
alfalfa de secano & 3,2 & 4,1 \\
leguminosas & 3,3 & 3,4 \\
erial & 4,0 & 1,4 \\
viñedo & 1,3 & 0,9 \\
girasol & 1,0 & 0,1 \\
cereal sin cosechar & 0,9 & 0,02 \\
\hline
\end{tabular}

Uso de hábitat para cazar

Para el análisis de selección de hábitat de alimentación, se consideraron 218 individuos cazando (focalizaciones) registrados en el año 2001 y 78 focalizaciones en el año 2002.

Las proporciones de las parcelas usadas por los cernícalos primillas en los años 2001 y 2002 se indican en la tabla 3.

Cazaron en mayor proporción sobre los rastrojos de cereal. En menor medida sobre los barbechos arados y barbechos no arados. De manera escasa sobre la alfalfa de secano, los linderos y las leguminosas. Además, en el 2001 cazaron en eriales, pastizales y cereal sin cosechar. En ambos años no se registraron observaciones de caza en los regadíos, viñedos, girasoles y matorrales.

Las proporciones de las parcelas de cultivo usadas por los primillas frente a lo disponible se indican en las figuras 1 y 2 . En ambos años, los primillas usaron más de lo disponible las siguientes parcelas de cultivo: rastrojos de cereal, barbecho no arado y alfalfa de secano. En el año 2001, usaron más de lo disponible las leguminosas, mientras que en el 2002, los linderos. No usaron las parcelas de regadío, viñedo y matorrales. 
Tabla 3. Proporciones relativas de las parcelas utilizadas por los primillas para cazar (número de observaciones, n=218 en 2001 y $n=78$ en 2002) en el área de estudio durante el verano..

\begin{tabular}{lrr}
\hline \multicolumn{1}{c}{$\begin{array}{c}\text { Tipo de parcela } \\
\text { donde cazaron los } \\
\text { primillas }\end{array}$} & \multicolumn{2}{c}{$\%$ relativa } \\
\cline { 2 - 3 } & año 2001 & año 2002 \\
\hline rastrojo de cereal & 70,2 & 78,2 \\
barbecho arado & 11,5 & 6,4 \\
barbecho no arado & 4,1 & 6,4 \\
alfalfa de secano & 3,7 & 3,8 \\
lindero & 1,8 & 3,8 \\
leguminosas & 5 & 1,3 \\
erial & 2,3 & 0,0 \\
pastizal & 0,9 & 0,0 \\
cereal sin cosechar & 0,5 & 0,0 \\
\hline
\end{tabular}

Tras la aplicación del índice de Savage (ver tabla 4) y determinación del significado estadístico, se comprobó que los primillas seleccionaron, en ambos años, significativa y positivamente las parcelas de rastrojo de cereal y seleccionaron negativamente los barbechos arados y los regadíos (y pastizales en el 2001).

Los otros tipos de cultivo lo usaron según su disponibilidad (no significativamente): la alfalfa de secano, el barbecho no arado, las leguminosas (en el 2001), y los linderos (en el 2002). En los viñedos, matorrales, eriales, pastizales, cereal sin cosechar y girasoles no se registró ninguna focalización.

A partir de los valores del índice de Savage se estableció un orden de preferencias de hábitat de alimentación por el Cernícalo Primilla durante este periodo post-reproductor o premigratorio (signo de selección en paréntesis, si fue estadísticamente significativo, y sin signo: no significativo):

i) Para el 2001: rastrojo(+) > leguminosas $>$ barbecho no arado $>$ alfalfa de secano $>$ lindero $>$ erial $>$ cereal $\sin$ cosechar $>$ barbecho arado $(-)>$ pastizal $(-)>$ cultivos de regadío $(-)>$ viñedo $>$ matorral.

ii) Para el 2002: rastrojo(+) $>$ lindero $>$ barbecho no arado $>$ alfalfa de secano $>$ leguminosas $>$ erial $>$ cereal $\sin$ cosechar $>$ barbecho arado ()>pastizal > cultivos de regadío (-) > viñedo $>$ matorral. 

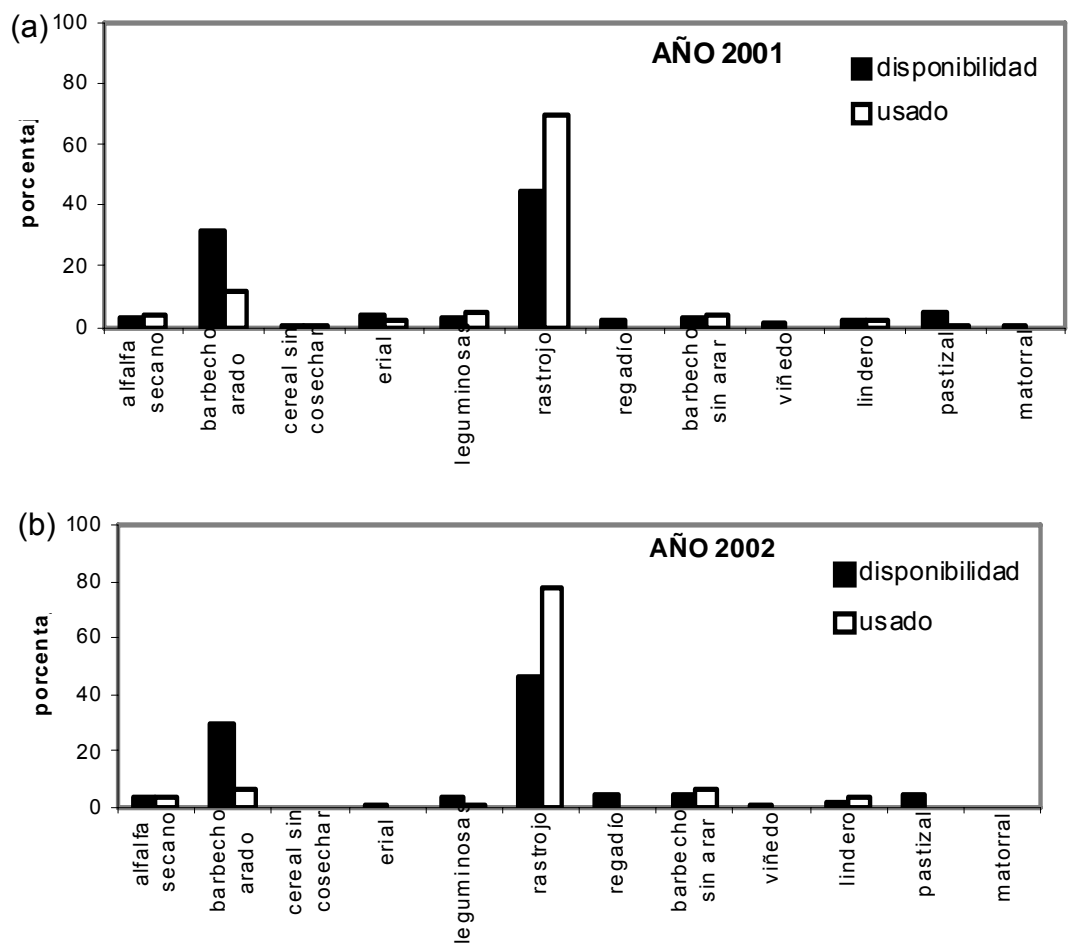

Figura 1. Proporciones relativas de parcelas disponibles (barra negra) y usadas (barra blanca) por el Cernícalo Primilla en el área de estudio (Sureste de León) durante el verano del año año 2001 (a) y 2002 (b).

\section{Discusión}

Los cernícalos primillas seleccionaron positivamente las parcelas de rastrojo de cereal de secano para cazar y seleccionaron negativamente los barbechos arados, pastizales y los regadíos en los dos años estudiados. El resto de cultivos (barbecho no arado, alfalfa de secano, lindero, leguminosas) lo usaron según su disponibilidad. Estos resultados son similares a los obtenidos por Tella y Forero (2000) durante el periodo invernal en Los Monegros, donde los primillas seleccionaron positivamente los rastrojos y linderos, y negativamente los barbechos arados, matorrales, cereales sin cosechar y regadíos. A diferencia de nuestro estudio, en el de Tella y Forero (2000) los primillas seleccionaron los linderos. Esta diferencia podría deberse a que en Los Monegros es un 
área semiárida y los linderos presentan una vegetación de menor porte y densidad que la nuestra (JL Tella com. pers.), siendo más fácil de cazar en los linderos

Tabla 4. Valores del índice de Savage, del error estadístico (s.e.) y la probabilidad tras aplicar el test de la prueba Chi-cuadrado (indicando si $\mathrm{p}<0.05)$ para cada tipo de parcela disponible en el verano de 2001 y de 2002. Los valores del índice de Savage con $\left(^{*}\right)$ indican que son estadísticamente significativos.

\begin{tabular}{lcccccccc}
\hline \multirow{2}{*}{ Tipo de parcela } & \multicolumn{3}{c}{ Año 2001 } & & \multicolumn{3}{c}{ Año 2002 } \\
\cline { 2 - 3 } \cline { 7 - 8 } & Savage $\left(\mathrm{w}_{\mathrm{i}}\right)$ & s.e. $\left(\mathrm{w}_{\mathrm{i}}\right)$ & $P$ & & Savage $\left(\mathrm{w}_{\mathrm{i}}\right)$ & s.e. $\left(\mathrm{w}_{\mathrm{i}}\right)$ & $P$ \\
\hline rastrojo de cereal & 1,6 & 0,08 & $<0,05^{*}$ & & 1,7 & 0,72 & $<0,05^{*}$ \\
leguminosas & 1,6 & 0,38 & $>0,05$ & & 0,4 & 0,63 & $>0,05$ \\
barbecho no arado & 1,5 & 0,40 & $>0,05$ & & 1,4 & 0,51 & $>0,05$ \\
alfalfa de secano & 1,2 & 0,38 & $>0,05$ & & 1,0 & 0,57 & $>0,05$ \\
lindero & 0,8 & 0,45 & $>0,05$ & & 2,2 & 0,86 & $>0,05$ \\
cereal sin cosechar & 0,6 & 0,75 & $>0,05$ & & 0,0 & 9,27 & $>0,05$ \\
erial & 0,6 & 0,34 & $>0,05$ & & 0,0 & 1,00 & $>0,05$ \\
barbecho arado & 0,4 & 0,10 & $<0,05^{*}$ & & 0,2 & 0,17 & $<0,05^{*}$ \\
pastizal & 0,2 & 0,31 & $<0,05^{*}$ & & 0,0 & 0,54 & $>0,05$ \\
regadío & 0,0 & 0,44 & $<0,05^{*}$ & & 0,0 & 0,51 & $<0,05^{*}$ \\
viñedo & 0,0 & 0,61 & $>0,05$ & & 0,0 & 1,20 & $>0,05$ \\
matorral & 0,0 & 1,60 & $>0,05$ & & 0,0 & 6,00 & $>0,05$ \\
\hline
\end{tabular}

Nuestro estudio reveló, por lo tanto, la importancia del rastrojo de cereal de secano dentro del agrosistema de secano extensivo, en régimen de año y vez, como principal parcela de alimentación durante el periodo premigratorio. Los artrópodos, principalmente ortópteros, constituyen la parte principal de la dieta del Cernícalo Primilla durante el periodo premigratorio (Franco \& Andrada 1977; Tejero et al. 1982; autores, datos no publicados). Algunos estudios han demostrado que la diversidad y abundancia de artrópodos es alta en los rastrojos de cereal dentro del paisaje agrícola (Tellería 1988; Moreira et al. 2004). Además estas parcelas son adecuadas para cazar debido al bajo porte de la vegetación, que proporciona una buena accesibilidad para la caza de presas (ver Henderson et al. 2000; Moreira et al. 2004, obs. pers.). Otros autores han sugerido que los rastrojos de cereal constituyen importantes áreas de alimentación para otras especies de aves esteparias amenazadas [ej. Avutarda (Lane et al. 2001) (Suárez et al. 1997)]. 
De Frutos y Olea (2008) observaron que, a una escala pequeña (círculos de $50 \mathrm{~m}$ de radio), la ocurrencia de primillas estuvo positivamente asociada con los rastrojos de cereal, además de a los barbechos no arados y linderos, los cuales fueron usados para cazar según su disponibilidad. Los barbechos no arados y linderos albergan también una alta diversidad y abundancia de artrópodos durante el verano (Tellería 1988; Henderson et al. 2000), pero el porte de la vegetación es mayor respecto a la de los rastrojos de cereal (observación personal), dificultando por tanto el acceso a la presa, y así su menor uso para cazar por el Primilla. Sin embargo, los barbechos no arados y linderos podrían actuar como fuente de presas (saltamontes), desde donde podrían dispersarse a otros lugares (ej. rastrojo de cereal; ver Douglas et al. 2009). Estos resultados refuerzan lo encontrado por De Frutos y Olea (2008) sobre la importancia que tiene el sistema agrícola extensivo, que permite la coexistencia de los cultivos con parches de vegetación natural (ej. barbechos no arados y linderos), para el Cernícalo Primilla durante el verano. Por consiguiente, grandes cambios en las prácticas agrícolas que eliminen los rastrojos de cereal o los parches de vegetación natural, como la implantación de cultivos intensivos, podrían afectar a la población de primillas en estas áreas usadas en el periodo premigratorio. Los cultivos de regadío fueron evitados por los primillas como hábitat de alimentación. Por tanto, la substitución del cultivo de secano extensivo por cultivos irrigados afectaría negativamente a esta población post-nupcial de primillas. No obstante, ciertos cultivos de regadío, como la alfalfa, con un menor porte relativo, les afectaría en menor medida respecto a otros cultivos de regadío (Donázar et al. 1993; Ursúa et al. 2005). De hecho, hemos registrado una cantidad relativamente alta de intentos de caza en alfalfa.

Las ayudas agroambientales que fomenten el sistema agrícola con cultivos extensivos, sobre todo de secano, podrían mantener la persistencia del Cernícalo Primilla en el área y de la biodiversidad agrícola en general (Stoate \& Parish 2001; Tilman et al. 2001; Benton et al. 2003; Green et al. 2005). Actualmente estas ayudas son de carácter voluntario y deberían ser prioritarias en la áreas premigratorias del Cernícalo Primilla, ya que su supervivencia podría depender del manejo de estas áreas. Se sabe que durante el periodo premigratorio algunas especies de aves migradoras, como el Cernícalo Primilla, necesitan abundantes recursos tróficos para realizar la muda (al menos 
parcialmente, ver Rivera et al. 1998) y acumular reservas grasas (Rivera et al. 1999) para llevar a cabo la migración, por lo que estas ayudas garantizarían el mantenimiento de áreas de caza adecuadas en el área.

\section{Agradecimientos}

Agradecemos la colaboración en el trabajo de campo de Hugo Robles, Rubén Vera, Olga Mora, Enrique Osorio, Cristina Trigal, María del Carmen Cordero, Soledad, Irene Marcos, Rodolfo Pozuelo y Rafael Gonzalez. Álvaro de La Puente, Jesús Fernández y Rafael González nos facilitaron sus telescopios. A.F disfrutó de una beca predoctoral concedida por la Universidad de León. Este trabajo ha sido parcialmente financiado por la Fundación Monteleón-Caja España.

\section{Referencias}

Atienza, J.C. \& Tella, J.L. 2004. Cernícalo Primilla, Falco naumanni, In Libro rojo de las aves de España. eds A. Madroño, C. González, J.C. Atienza, p. 452 p. Dirección general para la Biodiversidad-SEO/BirdLife, Madrid. España.

Benton, T.G., Vickery, J.A. \& Wilson, J.D. 2003. Farmland biodiversity: is habitat heterogeneity the key? Trends in Ecology \& Evolution 18, 182-188.

BirdLife International 2009. Falco naumanni, In Species factsheet: Falco naumanni. Downloaded from http://www.birdlife.org on 10/2/2009. ed. IUCN.

Blanco, G. \& Tella, J.L. 1999. Temporal, spatial and social segregation of redbilled choughs between two types of communal roost: a role for mating and territory acquisition. Animal Behaviour 57, 1219-1227.

De Frutos, A. \& Olea, P.P. 2008. Importance of the premigratory areas for the conservation of lesser kestrel: space use and habitat selection during the post-fledging period. Animal Conservation 11, 224-233.

Donázar, J.A., Negro, J.J. \& Hiraldo, F. 1993. Foraging habitat selection, land-use changes and population decline in the lesser kestrel Falco naumanni. Journal of Applied Ecology 30, 515-522.

Douglas, D.J.T., Vickery, J.A. \& Benton, T.G. 2009. Improving the value of field margins as foraging habitat for farmland birds. Journal of Applied Ecology 46, 353-362.

Franco, A. 1980. Relativa subalimentación de Falco naumanni durante el periodo no reproductor en el valle del Guadalquivir. Donana Acta Vertebrata 7, 99- 
102.

Franco, A. \& Andrada, J.A. 1977. Alimentación y selección de presa en Falco naumanni. Ardeola 23, 137-187.

Franco, A.M.A. \& Sutherland, W.J. 2004. Modelling the foraging habitat selection of lesser kestrels: conservation implications of European Agricultural Policies. Biological Conservation 120, 63-74.

García, J.T., Morales, M.B., Martínez, J., Iglesias, L., De la Morena, E.G., Suárez, F. \& Viñuela, J. 2006. Foraging activity and use of space by Lesser Kestrel Falco naumanni in relation to agrarian management in central Spain. Bird Conservation International 16, 83-95.

Green, R.E., Cornell, S.J., Scharlemann, J.P.W. \& Balmford, A. 2005. Farming and the fate of wild nature. Science $307,550-555$.

Henderson, I.G., Cooper, J., Fuller, R.J. \& Vickery, J. 2000. The relative abundance of birds on set-aside and neighbouring fields in summer. Journal of Applied Ecology 37, 335-347.

Heredia, B., Rose, L. \& Painter, M. 1996. Globally threatened birds in Europe. Action plans. Council of Europe Publishing. Birdlife International, Strasbourg.

Hiraldo, F., Bustamante, J. \& Donázar, J.A. 1995. On raptor roadside surveys in Western Turkey and Eastern Greece. Journal of Raptor Research 29, 145145.

Lane, S.J., Alonso, J.C. \& Martín, C.A. 2001. Habitat preferences of great bustard Otis tarda flocks in the arable steppes of central Spain: are potentially suitable areas unoccupied? Journal of Applied Ecology 38, 193-203.

Manly, B.F.J., McDonald, L.L. \& Thomas, D.L. 1993. Resource selection by animals: statistical design and analysis for field studies, 1st edn. Chapman \& Hall, London ; New York.

Moreira, F., Morgado, R. \& Arthur, S. 2004. Great bustard Otis tarda habitat selection in relation to agricultural use in southern Portugal. Wildlife Biology 10, 251-260.

Negro, J.J. 1991. Problemas de identificación. El cernícalo vulgar y el primilla. La Garcilla, 5-7.

Olea, P.P. 2001. Postfledging dispersal in the endangered Lesser Kestrel Falco naumanni. Bird Study 48, 110-115.

Olea, P.P., Vera, R., De Frutos, A. \& Robles, H. 2004. Premigratory communal roosts of the Lesser Kestrel in the boreal summer. Journal of Raptor Research 38, 278-282.

Parr, S.J., Naveso, M.A. \& Yarar, M. 1997. Habitat and potential prey surrounding lesser kestrel Falco naumanni colonies in central Turkey. Biological Conservation 79, 309-312.

Petit, S. \& Firbank, L. 2006. Predicting the risk of losing parcels of semi-natural habitat to intensive agriculture. Agriculture Ecosystems \& Environment 115, 277-280. 
Rivera, J.H.V., McShea, W.J., Rappole, J.H. \& Haas, C.A. 1999. Postbreeding movements and habitat use of adult wood thrushes in northern Virginia. Auk 116, 458-466.

Rivera, J.H.V., Rappole, J.H., McShea, W.J. \& Haas, C.A. 1998. Wood thrush postfledging movements and habitat use in northern Virginia. Condor 100, 69-78.

Steenhof, K., Kochert, M.N. \& Moritsch, M.Q. 1984. Dispersal and migration of southwestern Idaho raptors. Journal of Field Ornithology 55, 357-368.

Stoate, C. \& Parish, D. 2001. Crops grown on set-aside land bring wild birds back to the fields - Monitoring is under way, and results so far are promising. Nature 414, 687-687.

Suárez, F., Naveso, M.A. \& De Juana, E. 1997. Farming in the drylands of Spain: birds of the pseudosteppes, In Farming and Birds in Europe. eds D. Pain, M.W. Pienkowski, pp. 297-330. Academic Press, London, UK.

Tejero, E., Soler, M., Camacho, I. \& Ávila, J.M. 1982. Contribución al conocimiento del régimen alimenticio del Cernícalo Primilla (Falco naumanni Fleish 1758). Boletín de la Estación Central de Ecología 22, 7782.

Tella, J.L. \& Forero, M.G. 2000. Farmland habitat selection of wintering lesser kestrels in a Spanish pseudosteppe: implications for conservation strategies. Biodiversity and Conservation 9, 433-441.

Tella, J.L., Forero, M.G., Hiraldo, F. \& Donázar, J.A. 1998. Conflicts between lesser Kestrel conservation and European agricultural policies as identified by habitat use analyses. Conservation Biology 12, 593-604.

Tellería, J.L. 1988. Avifauna de los campos de cereales del interior de España. Sociedad Española de Ornitología, Madrid, Spain.

Tilman, D., Fargione, J., Wolff, B., D'Antonio, C., Dobson, A., Howarth, R., Schindler, D., Schlesinger, W.H., Simberloff, D. \& Swackhamer, D. 2001. Forecasting agriculturally driven global environmental change. Science 292, 281-284.

Ursúa, E., Serrano, D. \& Tella, J.L. 2005. Does land irrigation actually reduce foraging habitat for breeding lesser kestrels? The role of crop types. Biological Conservation 122, 643-648.

Ursúa, E. \& Tella, J.L. 2001. Unusual large communal roosts of Lesser Kestrel in two electric substations of Northern Spain: implications for the conservation of Spanish population, In Abstracts of the $4^{\text {th }}$ Eurasian Congress on Raptors. eds J. Bustamante, G. Crema, E. Casado, J. Seoane, C. Alonso, C. Rodríguez, M. de Lucas, G. Janss, p. 188. Estación Biológica de Doñana and Raptor Research Foundation, Sevilla, Spain. 


\section{Conclusiones}

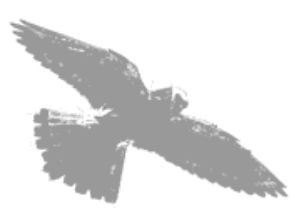



1. Los dormideros estivales de Cernícalo Primilla son usados, año tras año, desde mediados de julio hasta finales septiembre, con el número máximo de aves en agosto. En el área de estudio se congregan cerca de 1.000 cernícalos primillas en los 7 dormideros estivales estudiados. Esta población post-nupcial es alrededor de un orden de magnitud mayor que la población reproductora local, indicando que gran parte de la población estudiada proviene de otras áreas reproductoras.

2. Los cernícalos primillas se desplazan hasta $9 \mathrm{~km}$ del dormidero y retornan diariamente al mismo dormidero para pasar la noche. Exhiben el comportamiento de refugio durante el verano sin producirse intercambio de individuos entre dormideros estivales. El área de campeo en torno a los dormideros fue de promedio 346.8 ha, 92.7 ha de las cuales fueron intensivamente usadas.

3. La distribución de la abundancia de Cernícalo Primilla en el periodo estival está espacialmente agregada a una resolución de $4 \mathrm{~km}$. Es necesario considerar este patrón espacial a la hora de diseñar muestreos de abundancia de cernícalos primillas durante el verano.

4. Los modelos de distribución de Cernícalo Primilla a escala de paisaje tienen mayor capacidad predictiva cuando se considera la estructura espacial de la abundancia de primillas. Esta abundancia está principalmente explicada por factores endógenos (organización social y atracción conespecífica), siendo muy poco explicada por variables de paisaje.

5. A una escala menor (de área de campeo y áreas usadas intensamente), los cernícalos primillas radio-marcados seleccionan positivamente las áreas agrícolas extensivas de secano. Dentro de estas áreas, los primillas evitaron los cultivos de regadío. Los requerimientos de hábitat cambian según la escala considerada y, por ello, es necesario tenerlo en cuenta en futuros estudios de selección de hábitat por el Cernícalo Primilla durante el verano. 
6. Los barbechos, junto con los rastrojos de cereal de secano y los linderos, influyeron positivamente en la presencia de primillas durante el verano a una escala más fina. La reciente aprobación de la abolición del barbecho obligatorio puede afectar negativamente al Cernícalo Primilla, particularmente si se reduce la superficie de barbecho a expensas de un aumento de la superficie de cultivos de maíz, evitados por los primillas.

7. A escala de cultivo, los cernícalos primillas cazan en los rastrojos de cereal de secano, mientras que evitan los cultivos de regadío (maíz), barbechos arados y pastizales. Esto enfatiza la importancia que tiene el sistema agrícola extensivo de secano como zona de alimentación en las áreas premigratorias.

8. Para garantizar la conservación del Cernícalo Primilla durante el periodo premigratorio, las áreas distanciadas hasta $9 \mathrm{~km}$ de los dormideros necesitan ser protegidas legalmente. Se debe priorizar en estas áreas la implementación de ayudas agroambientales que fomenten la extensificación agrícola con un mosaico de cultivos, especialmente cereal de secano, con parches semi-naturales (linderos y barbechos) y evitando la masificación de cultivos de regadío, especialmente de maíz. 


\section{ANEXO}

\section{Implicaciones en la conservación y gestión ambiental del uso del módulo estadístico de partición jerárquica}

Using the Hierarchical Partitioning Public-Domain Software: Implications in Environmental Management and Conservation. Olea, P.P. \& De Frutos, Á. Submitted to PlosOne. 


\section{Resumen}

La partición jerárquica (HP) es un método analítico de regresión múltiple usado para identificar los factores causales más probables evitando posibles problemas de multicolinealidad. Este método se usa cada vez más en ecología y conservación, bien como herramienta principal o bien como complementaria a los análisis de regresión múltiple (por ejemplo GLM). El módulo informático gratuito "hier.part package" permite realizar de forma rutinaria este análisis con el programa estadístico R. Sin embargo, este módulo produce, según sus autores, un pequeño error de redondeo cuando se usan más de 9 variables.

La robustez de este módulo se analizó y cuantificó en relación al número y orden de las variables incluidas en los análisis, usando tanto simulaciones numéricas y datos reales de abundancia de Cernícalo Primilla. Los resultados indicaron que hubo un considerable efecto del orden de las variables en la cantidad de varianza independiente explicada cuando se usan más de 9 variables en los modelos. Además, en estos modelos se observó que el orden de importancia de las variables, por su contribución de varianza explicada de la variable respuesta, cambió según el orden de estas variables, es decir, los predictores más importantes pasaron a ser menos importantes cuando, con el mismo número de variables, se introdujeron en diferente orden.

El módulo de HP es una excelente herramienta tanto si se usa sola como si se usa para complementar a los análisis de regresión múltiple (por ejemplo los GLM). Sin embargo, su aplicación debe tratarse con cautela cuando se usan más de 9 variables debido a la elevada inconsistencia de los resultados. Este inconveniente debería ser considerado tanto en futuros estudios como en aquellos ya publicados. 


\begin{abstract}
Hierarchical partitioning (HP) is an analytical method of multiple regression that identify the most likely causal factors while alleviating multicollinearity problems. Use of HP is increasing in ecology and conservation by its usefulness for complementing multiple regression analysis, such as GLMs. A hierarchical partitioning public-domain software "hier.part package" has been developed for running in R software. According to their authors the function produces a "minor rounding error" for hierarchies constructed from more than 9 variables.
\end{abstract}

By means of numerical simulations and a real example, we analysed and quantified the robustness of this HP module of $R$ in relation to the order the variables have in the analysis. Results indicated that there was a considerable effect of the variable order on the amount of independent variance explained by predictors for models consisting of more than 9 independent variables. More importantly, for these models the nominal ranking of importance of the predictors changed with variable order, i.e. predictors declared important by its contribution in explaining the response variable frequently changed to be either most or less important with other variable orders.

The HP module is an excellent tool either by itself or in combination with multiple regression analysis (eg. GLMs). However, it should be applied with caution when more than 9 explanatory variables are used because of the marked inconsistency of their HP results. This inconsistency should be considered in future studies as well as in those already published.

Keywords: collinearity, independent explained variance, priorities of conservation, shared variance, $\mathrm{R}$ statistical software. 


\section{Introduction}

In recent years multiple regression analysis (e.g. GLMs) is widely used in ecology and conservation biology. This statistical approach to modelling can be seriously affected by multicollinearity between the explanatory variables, i.e. correlation among them (e.g. Graham 2003). An analytical method named hierarchical partitioning (HP hereafter; Chevan \& Sutherland 1991) reduces collinearity problems by determining the independent contribution of each explanatory variable to the response variable and separates it from the joint contribution, resulting from correlation with other variables (Mac Nally 2000). Given its usefulness for complementing multiple regression analysis and by the recent developing of a free module ("hier.part package" Walsh \& Mac Nally 2004, 2005)) for running in $\mathrm{R}$ (a free statistical software), the use of HP is increasing in different research fields. This increase can be measure using the Thomson Institute (ISI Web of Science) bibliographic data base (1900-31 December 2008) to identify all papers indexed that cited the HP package of Mac Nally and Walsh (i.e. Mac Nally 2000, 2002; Mac Nally \& Walsh 2004). Using this bibliometric approach, we found a total of 242 studies distributed in 33 subject categories (Fig. 1). The increase in the number of papers was predominant in the "ecology" subject category and, to a lesser extent, in the "biodiversity conservation" and "environmental sciences" subject categories (e.g. Gibson et al. 2004; Heikkinen et al. 2004; Walsh et al. 2004; Heikkinen et al. 2005; McAlpine et al. 2006; Buse et al. 2007; Carrete et al. 2007; De Frutos et al. 2007; Leprieur et al. 2008; Chiron et al. 2009).

HP produces, according to authors, a "minor rounding error" with models comprised of more than 9 explanatory variables (Walsh \& Mac Nally 2005, 2007). Several works have already used these HP modules for developing ecological models on biodiversity (e.g. Heikkinen et al. 2004; Heikkinen et al. 2005; Marini et al. 2008), conservation (Gibson et al. 2004; McAlpine et al. 2006; Carrete et al. 2007), environmental monitoring (Millington et al. 2007), forest management for conservation (Müller et al. 2009) and predicting the response of biodiversity to climate 
change (Luoto et al. 2006). Some of these studies ran models with more of 9 variables and the potential bias by using these HP modules from R has not yet been examined. Knowing this bias is pivotal because the ranking obtained in HP is becomes used as criterion for establishing priorities of conservation (Carrete et al. 2007).

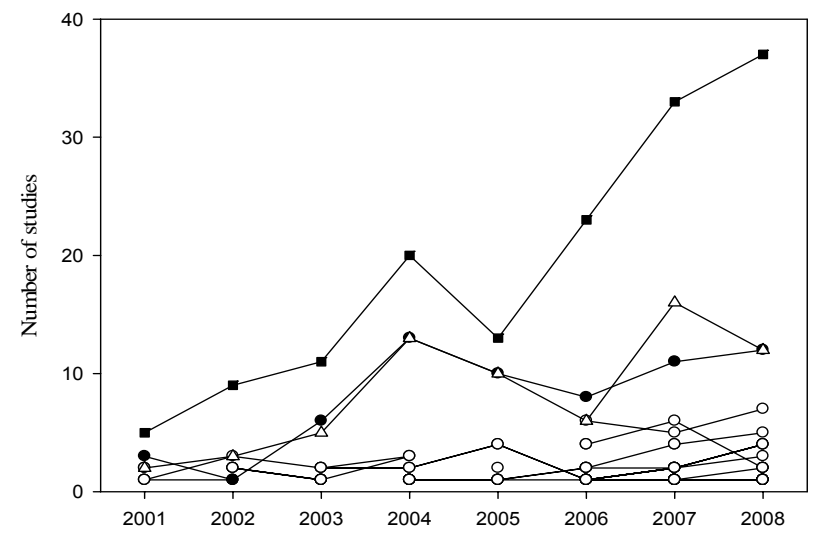

Figure 1. Temporal trends in the number of studies that cited the HP module of Mac Nally and Walsh (Mac Nally 2000, 2002, Mac Nally \& Walsh 2004), distributed among 33 subject categories distinguished by ISI Web of Science. Filled squares, filled circles and opened triangles represent the "ecology", "biodiversity conservation" and "environmental sciences" subject categories, respectively. Opened circles represent the other 30 subject categories.

In this paper, we show that these HP modules produce a considerable inconsistency for analyses with more than 9 independent variables. This bias is here quantified to aid researchers to make a proper assessment of the results obtained with implications in environmental management and conservation. Firstly, by means of numerical simulations we examine and quantify the robustness of the HP modules for running in R; particularly, we research for the potential variation in results obtained in relation to the order the variables are entered into the analysis. Secondly, we address these issues in a real example worked on factors affecting the abundance of a threatened species. Finally, we give some recommendations to improve the analysis with this hierarchical partitioning statistical package. 


\section{Methods}

For the analysis we used "hier.part" package (version 1.0 and updates; Walsh \& Mac Nally 2004) in the R statistical package ( $R$ Development Core Team 2006). The method of fitting the model to data was by least squares (i.e. the goodness-of-fit measures were calculated by R-squared; argument in R statistical package: gof = "Rsqu", see Walsh \& Mac Nally 2007).

In order to assess the potential impact of the variable order on the HP results, we built a data set with 13 variables (Dataset-1), consisting of one response variable $(Y)$ and twelve predictor variables (the module of hierarchical partition "hier.part" for using in R statistical package does not run for more than twelve predictor variables; Walsh \& Mac Nally 2007). The variables were generated by using the multivariate Normal distribution function "rmvnorm" in SPLUS 2000; this function generates correlated random numbers. All the 13 variables had a gaussian distribution with $n=25$ and standard deviation (SD) equal to 1. Four variables $\left(X_{A}, X_{B}, X_{C}\right.$ and $\left.X_{D}\right)$ had a correlation coefficient with the response variable $(Y) r<0.10$ (i.e. each of these variables explained $<1 \%$ of the variance of the response variable, $r^{2}<1 \%$ ), for the rest of variables see Table 1. Of course, these correlation coefficients with the response variable were arbitrarily chosen but it can be assumed to be representative of many real situations. From the data set of twelve predictor variables, we selected subsamples (vectors) of $2,3,4,5, \ldots$ and so on up to twelve variables by using the function "sample" in R. Then each of these eleven vectors generated were reshuffled 100 times by using the same function "sample" (i.e. the position of same variables was randomly changed within the vector), and HP was run for each of the subsamples generated (previously converted in data frames). By using this procedure, we obtained results of HP for vectors containing the same suite of variables but in different order and so it allowed us to test the potential impact of the position of the variables on HP results. Specifically, we measured how often the nominal order of relative importance of predictors (according to amount of explained independent variance) was changed after permuting the variable order in the models. In order to examine potential changes among models with same suite of predictor variables 
but differently ordered, we used as reference model that with predictors following alphabetic order (e.g. see Table 1).

Table 1. Independent, joint and total variance explained (in percentage) for each of the variables* taken into account in the numerical simulation (Dataset-1, see text). Note that the total explained variance (Total column) expresses the correlation (in " $R^{2 \prime}$ ) of each of the variables with the response variable (for example, $X_{A}, X_{B}, X_{C}$ and $X_{D}$ have a correlation coefficient with the response variable $Y, r<0.10$, i.e. each of them explain $<1 \%$ of the variance of the response variable, $r^{2}<1 \%$ ). Negative joint variance indicates that the other variables act as suppressors of the particular variable.

\begin{tabular}{cccc}
\hline Variables & Independent & Joint & Total \\
\hline$X_{A}$ & 5,39 & $-4,99$ & 0,40 \\
$X_{B}$ & 5,72 & $-4,87$ & 0,85 \\
$X_{C}$ & 5,31 & $-4,61$ & 0,70 \\
$X_{D}$ & 5,33 & $-5,17$ & 0,16 \\
$X_{E}$ & 7,78 & 0,77 & 8,55 \\
$X_{F}$ & 6,78 & $-0,63$ & 6,15 \\
$X_{G}$ & 6,53 & 0,53 & 7,06 \\
$X_{H}$ & 6,15 & $-1,47$ & 4,68 \\
$X_{1}$ & 11,35 & 12,17 & 23,52 \\
$X_{J}$ & 7,60 & 10,99 & 18,59 \\
$X_{K}$ & 12,94 & 12,80 & 25,75 \\
$X_{L}$ & 13,61 & 21,52 & 35,13 \\
\hline
\end{tabular}

*The variable order shown in the table is the order used for this analysis of hierarchical partitioning.

We also measured the change produced in the explained independent variance, comparing the results of HP of the reference model with each of the reshuffled vectors. Specifically, each of the variables of the reference model was compared with the same variables of each of the 100 reshuffled vectors. As the change in percentage may be negative and the direction of the change was not important here, we taken these differences as absolute values, $|\mathrm{d}|$. This comparative procedure was done for HP1, HP2 and HP3. Nine new data sets (Dataset 2-10) were generated with the same procedure that for Dataset-1 (see above) but with different correlation patterns. 
A real example worked: Abundance of a threatened falcon in an agricultural landscape

Data of this example worked come from a previous paper (De Frutos et al. 2007). In this example, we examine the spatial pattern of lesser kestrel (Falco naumanni) abundance in function of a set of environmental factors at landscape level (Table 4). This species is a small falcon breeding in the Palaearctic and wintering mainly in Africa (Siegfried \& Skead 1971; Cramp \& Simmons 1980), and is considered to be a globally threatened species listed as Vulnerable (BirdLife International 2004). The study area $\left(384 \mathrm{~km}^{2}\right)$ was divided into 24 contiguous UTM grid $4 \mathrm{~km} \times 4 \mathrm{~km}$ $\left(16 \mathrm{~km}^{2}\right)$ squares, where birds were counted in up to 3 visits per square. An index of relative density (IRD, no. of lesser kestrels in $1 \mathrm{~km}$ of driven transect) was calculated for each grid and each visit. Then, the averages of IRD of the visits performed per square were calculated for each grid (response variable). Environmental variables were measured within strips $250 \mathrm{~m}$ wide at each side of the routes for censusing kestrels and were extracted with aid of a geographic information system (GIS software, ARCGIS 8.0). Eleven independent variables were considered (Table 4). Lesser kestrel abundance was log-transformed $(\ln [x+0.5])$ to reach normal distribution. The method of fitting the model to data in HP was by least squares (i.e. the goodness-of-fit measures were calculated by R-squared).

\section{Results}

There was an effect of the variable order for models consisting of more than 9 variables (Table 2). In other words, a same variable within the same set of 10-12 variables but entered in different order changed their ranking of relative importance, based in independent explanatory power of the response variable. For models with ten variables, this nominal ranking changed in the $93 \%$ of the times (Table 2). Taking as reference other variable orders randomly chosen, this result were roughly the same than for that of alphabetic order (mean=91.3\%, range $=89-95$, $\mathrm{n}=10$ ). For models with eleven variables the order of importance of the predictors changed in the $99 \%$ of the times and the $100 \%$ with twelve variables. This result changed little whether for determining changes it was considered all the predictors or only those variables with most 
independent explanatory power (Table 2). This result also remained the same for the nine data sets (Dataset 2-10) generated with the same procedure that for Dataset-1 (see above) but with different correlation patterns.

Table 2. Number of times $(n=100)$ that the ranking of importance of predictors changed relative to the reference order (i.e. that following order alphabetic for analysis) when other variable orders were analysed by hierarchical partitioning for models from two to twelve predictors.

\begin{tabular}{|c|c|c|}
\hline $\begin{array}{l}\text { Number of } \\
\text { predictors }\end{array}$ & $\begin{array}{l}\text { Change of } \\
\text { ranking }(\%)^{*}\end{array}$ & $\begin{array}{l}\text { Change } \\
\text { ranking }(\%) \S\end{array}$ \\
\hline Two & 0 & 0 \\
\hline Three & 0 & 0 \\
\hline Four & 0 & 0 \\
\hline Five & 0 & 0 \\
\hline Six & 0 & 0 \\
\hline Seven & 0 & 0 \\
\hline Eight & 0 & 0 \\
\hline Nine & 0 & 0 \\
\hline Ten & 93 & 61 \\
\hline Eleven & 99 & 99 \\
\hline Twelve & 100 & 100 \\
\hline
\end{tabular}

*Considering all the predictors

$\S$ Considering first five predictors most important by independent explanatory power

Predictors declared as the most important by their independent explanatory power appeared in different ranking of importance in models with different orders of the same set of variables (Table 3). One predictor ranked first by amount of independent explanatory power in the reference order ( i.e. following alphabetic order) appeared second $(22.5 \%$ of the times) and third (5\%) with other variable orders in analysis of hierarchical partitioning for models from ten to twelve independent variables.

Mean percentage of change $|d|$ in explaining independent variance for models with 10 variables ranged of 0.18 to $63.6 \%$ across the 100 estimates. The mean value of $|\mathrm{d}|$ was $37.2 \%$ (SD: 14.66). For 11 variables, mean $|\mathrm{d}|$ ranged of 0 to $63.5 \%$ (mean: $41.1 \%$, SD: 16.28). For 12 variables, mean $|d|$ ranged of 7.4 to $66.1 \%$ (mean: $42.8 \%$; SD: 14.29 ). 
Throughout all of the analysis the results were exactly the same for the different versions of HP.

Table 3. Number of times (percentage relative to 300) that the position of a particular predictor ranked (from first to third) by amount of independent explanatory power and analysed in the reference order ( i.e. following alphabetic order) appeared in different positions of importance with other variable orders in analysis of hierarchical partitioning for models from ten to twelve independent variables*.

\begin{tabular}{lccccccccccccc} 
& \multicolumn{10}{c}{ Position with other variable orders } \\
\cline { 2 - 13 } $\begin{array}{l}\text { Position in } \\
\text { reference }\end{array}$ & $1^{\circ}$ & $2^{\circ}$ & $3^{\circ}$ & $4^{\circ}$ & $5^{\circ}$ & $6^{\circ}$ & $7^{\circ}$ & $8^{\circ}$ & $9^{\circ}$ & $10^{\circ}$ & $11^{\circ}$ & $12^{\circ}$ \\
order & & & & & & & & & & & & \\
\hline First & 72.4 & 22.3 & 5.0 & 0 & 0 & 0 & 0 & 0 & 0 & 0 & 0 & 0 \\
Second & 23.3 & $\mathbf{6 5 . 4}$ & 9.6 & 0.3 & 0.3 & 0 & 0 & 0 & 0 & 0 & 0 & 0.3 \\
Third & 3.7 & 10.3 & $\mathbf{7 5 . 4}$ & 10.0 & 0 & 0.3 & 0 & 0 & 0 & 0 & 0 & 0.3 \\
\hline
\end{tabular}

* Note that the frecuency of change for models of ten, eleven and twelve predictors was pooled

Although we did not quantify it, models with a binomial response variable (e.g. presence/absence; argument of goodness-to-fit "logLik" see Walsh \& Mac Nally 2007 for more details), had as well an effect of the variable order in models with more than 9 variables.

\section{Real example worked}

In table 5 is shown the independent, joint and total variance explained for each of the predictors of lesser kestrel abundance in the reference order (alphabetic). The five variables that most variance explained in abundance of lesser kestrel were AUTOCOV4 (11.94\%), FARMLAND (6.71), DROOST (5.41), FOREST (5.15) and DCOLONY10 (4.17). The position of these variables in the ranking (according to percentage of independent variance) changed in models with other variable orders (Table 6). The exception to this was AUTOCOV4, whose first position did not change for models with other variable orders (Table 6), although it changed the amount of independent variance explained. Percentage of independent variance changed in all the five variables in the ranking a mean of $14.4 \%(S D=7.60$, range=9.5-27.6; $n=5)$. 
Table 4. Independent variables used for explaining the distribution of lesser kestrel abundance in a Spanish farmland during the postbreeding period, summer 2002.

\begin{tabular}{|c|c|}
\hline Variable & Definition \\
\hline Farmland (FARMLAND) & Surface in $\%$ of farmland \\
\hline Grassland (GRASSLAND) & Surface in \% of grassland \\
\hline Forest (FOREST) & Surface in $\%$ of forest \\
\hline Build-up areas (BUILD-UP) & Surface in $\%$ of build-up areas \\
\hline $\begin{array}{l}\text { Habitat edge density } \\
\text { (EDGE) }\end{array}$ & Total edge length in $\mathrm{km}$ of all habitat patches per $\mathrm{km}^{2}$ \\
\hline $\begin{array}{l}\text { Landscape heterogeneity } \\
\text { (SHANDIVER) }\end{array}$ & Habitat diversity using Shannon's diversity index \\
\hline Electrical wires (WIRE) & Total length in $\mathrm{km}$ of electrical wires \\
\hline $\begin{array}{l}\text { Distance to the nearest } \\
\text { colony (DCOLONY10) }\end{array}$ & $\begin{array}{l}\text { Distance in } \mathrm{km} \text { to the nearest colony with more than } 10 \\
\text { breeding pairs from the centre of each grid square }\end{array}$ \\
\hline $\begin{array}{l}\text { Distance to the nearest roost } \\
\text { (DROOST) }\end{array}$ & $\begin{array}{l}\text { Distance in } \mathrm{km} \text { to the nearest roost from the centre of } \\
\text { each grid square }\end{array}$ \\
\hline $\begin{array}{l}\text { Autocovariate from } 4 \mathrm{~km} \\
\text { (AUTOCV4) }\end{array}$ & $\begin{array}{l}\text { Average of kestrel IRD in the } 8 \text { nearest neighbour } \\
\text { squares; it allows to explain for spatial autocorrelation }\end{array}$ \\
\hline Effort (EFFORT) & No. of visits in each square to count birds \\
\hline
\end{tabular}

The change in independent variance for each variable is given in table 7. The variable most changed among models was AUTOCOV4 ranging from 18 to $53.3 \%$ (mean=27.62\%, SD= 4.18). There was a positive correlation between explained independent variance by each of the variables in the reference order and their observed percentage of change when the order of the variables varied $\left(r_{\mathrm{s}}=1.0 ; P=0.057, Z=1.9 ; n=5\right)$. That is, variables with most independent variance changed to a greater extent when variable order changed. Throughout all of the analysis the results were exactly the same for the different versions of HP.

\section{Discussion}

In the analyses explored here, the same set of variables in different order should produce the same results. However, for models with more than 9 variables we found that this was not true for more than $90 \%$ of the times. Specifically, a particular variable may be declared in a model as the most important predictor of the response variable but to be second or third in importance for models with same predictors but differently ordered in 
around the $27 \%$ of the times (as extreme cases a predictor second or third in importance may be twelfth; Table 3). In variables related to lesser kestrel abundance, the result was in general the same, with ranking of predictors frequently changing.

Table 5. Independent, joint and total variance explained (in percentage) for each of the predictors of abundance of lesser kestrel in a Spanish farmland during summer 2002. Note that the total explained variance (Total column) expresses the correlation (in " $R^{2 "}$ ) of each of the variables with the response variable. Negative joint variance indicates that the other variables act as suppressors of the particular variable.

\begin{tabular}{lccc}
\hline Variables & Independent & Joint & Total \\
\hline AUTOCOV4 & 11.94 & 23.41 & 35.35 \\
BUILDUP & 1.97 & -0.74 & 1.23 \\
DCOLONY10 & 4.17 & 8.04 & 12.21 \\
DROOST & 5.41 & 5.23 & 10.63 \\
EDGE & 1.53 & -1.13 & 0.40 \\
EFFORT & 2.66 & 1.85 & 4.51 \\
FARMLAND & 6.71 & 14.31 & 21.02 \\
FOREST & 5.15 & 11.13 & 16.28 \\
GRASSLAND & 1.46 & -1.08 & 0.38 \\
SHANDIVER & 3.01 & 5.34 & 8.35 \\
WIRE & 2.39 & -0.48 & 1.91 \\
\hline
\end{tabular}

* The variable order shown in the table is the order used for this analysis of hierarchical partitioning.

The only exception to this was AUTOCOV4. This variable did not change their position in the ranking with models having other variable orders. However, this predictor considerably changed among models their amount of independent variance explained (18-53\% of change). Unlike the simulated example, first variable in the ranking of the real example (AUTOCOV4) did not change their top position. This may be because the difference in amount of independent variance between first position in the ranking and the following variable/s in the ranking (first: 11.9 vs second: 6.74 ) was larger than that of the simulated example (13.6 vs 12.9) (Table 5 and 1$)$. 
Table 6. Number of times (percentage relative to 100) that the position of a predictor of abundance of lesser kestrel ranked (from first to fifth) by amount of independent explanatory power and analysed in the reference order ( i.e. following alphabetic order) appeared in different positions of importance with other variable orders in analysis of hierarchical partitioning for models from eleven independent variables.

\begin{tabular}{lccccccccccc}
\hline & \multicolumn{10}{c}{ Ranking with other variable orders } \\
\cline { 2 - 11 } $\begin{array}{l}\text { Ranking in } \\
\text { reference order }\end{array}$ & $\mathbf{1}^{\mathbf{0}}$ & $\mathbf{2}^{\mathbf{0}}$ & $\mathbf{3}^{\mathbf{0}}$ & $\mathbf{4}^{\mathbf{0}}$ & $\mathbf{5}^{\mathbf{0}}$ & $\mathbf{6}^{\mathbf{0}}$ & $\mathbf{7}^{\mathbf{0}}$ & $\mathbf{8}^{\mathbf{0}}$ & $\mathbf{9}^{\mathbf{0}}$ & $\mathbf{1 0}^{\mathbf{0}}$ & $\mathbf{1 1}^{\mathbf{0}}$ \\
\hline 1 AUTOCOV4 & $\mathbf{1 0 0}$ & 0 & 0 & 0 & & & & & & & \\
2 FARMLAND & & $\mathbf{9 5}$ & $\mathbf{2}$ & & & & 1 & 2 & & & \\
3 DROOST & & 2 & $\mathbf{7 0}$ & 21 & 5 & & & 2 & & & \\
4 FOREST & & & 21 & $\mathbf{4 9}$ & 29 & & & & & & 1 \\
5 DCOLONY10 & & 3 & 9 & 30 & $\mathbf{5 2}$ & 4 & 1 & 1 & & & \\
\hline
\end{tabular}

Table 7. Mean, standard deviation and range of the change percentage in independent variance explained of the five best predictors of lesser kestrel abundance comparing the model in reference order (table 5) with models in others randomly chosen orders $(n=100)$.

\begin{tabular}{lcccc}
\hline & Mean & SD & Minimum & Maximum \\
\hline AUTOCOV4 & 27.62 & 4.18 & 18.00 & 53.30 \\
FARMLAND & 13.75 & 1.63 & 7.15 & 16.50 \\
DROOST & 10.93 & 1.16 & 6.90 & 14.34 \\
FOREST & 10.06 & 0.94 & 4.92 & 11.88 \\
DCOLONY10 & 9.48 & 1.05 & 5.66 & 11.65 \\
\hline
\end{tabular}

In other words, AUTOCOV4 had a larger room to vary without change of position in the ranking (Table 5 and 1 ). It is therefore expected that the frequency of change is to be higher with a lesser difference in independent variance explained by predictors. Indeed, DROOST, FOREST and DCOLONY10 had an amount of variance explained close each other and in consequence frequently changed their positions (Table5 and 6). Theses three variables frequently inter-changed their positions and thereby ranking of importance in explaining abundance of lesser kestrel was uncertain for these variables. 
The authors from the HP package (Walsh \& Mac Nally 2007) claims that the function produces a "minor rounding error" for analyses with more than 9 independent variables. In light of the results here obtained it seems that it rather produces a considerable inconsistency both quantitative and qualitative in the results. Whilst the cause of this unexpected variation in the HP results is unclear, what is clear is that these findings need to be taken into account in future studies as well as some already published. For example several works have already used the HP module (v1.0) with more than 9 explanatory variables in their models (e.g. Heikkinen et al. 2004; Banks et al. 2005; Heikkinen et al. 2005; Luoto et al. 2006; Millington et al. 2007; Marini et al. 2008), which might has lead to misleading conclusions about the importance of certain variables, with implications for environmental management and conservation.

Despite of this inconsistency in results, some patterns can be given. For example, it seems that the highest frequency attained in the ranking by particular predictors for models with 10-12 variables (Table 3 ) would be the "correct" position in the ranking, as judged by explanatory power of the predictors (Table 1). Because correct ranking is a priori no known in a single analysis, it should be run several times the model with different order of the set of 10-12 variables (as recommended by authors of the HP module; Walsh \& Mac Nally 2007). Knowing the ranking of importance of predictors is pivotal because this order has been for example used for establishing priorities of conservation, with consequent repercussions in wildlife managers (Carrete et al. 2007).

On the other hand, knowing the amount of explained variance by predictors in models with 10-12 variables is absolutely uncertain, as it hugely varies between models with same variables but differently ordered. No clear pattern emerged here and thereby variance explained is not a useful parameter to use in models with more than 9 independent variables.

In conclusion, if aim is to obtain amount of explained variance, we suggest that the HP module of $R$ should not be used for more than 9 explanatory variables because of the inconsistency of their results. If used for establishing ranking of importance of variables it should be applied with caution (see above). For 9 or less explanatory variables this HP 
module seems to work well and it currently is an excellent tool either by itself or in combination with multiple regression analysis (eg. GLMs), as shown by its increasing use in ecology and conservation.

\section{Acknowledgements}

We thank Javier Viñuela for its support at the Instituto de Investigación en Recursos Cinégéticos (IREC-CSIC) and to Steve Redpath, Ralph Mac Nally and Jesús G. Ochoa for value suggestions at the manuscript.

\section{References}

Banks, S.C., Finlayson, G.R., Lawson, S.J., Lindenmayer, D.B., Paetkau, D., Ward, S.J. \& Taylor, A.C. 2005. The effects of habitat fragmentation due to forestry plantation establishment on the demography and genetic variation of a marsupial carnivore, Antechinus agilis. Biological Conservation 122, 581-597.

BirdLife International 2004. Falco naumanni, In 2004 IUCN Red List of Threatened Species. http://www, redlist, org Downloaded on 03 May 2005. ed. IUCN.

Buse, J., Schroder, B. \& Assmann, T. 2007. Modelling habitat and spatial distribution of an endangered longhorn beetle - A case study for saproxylic insect conservation. Biological Conservation 137, 372-381.

Carrete, M., Grande, J.M., Tella, J.L., Sanchez-Zapata, J.A., Donazara, J.A., DiazDelgadoa, R. \& Romo, A. 2007. Habitat, human pressure, and social behavior: Partialling out factors affecting large-scale territory extinction in an endangered vulture. Biological Conservation 136, 143-154.

Chevan, A. \& Sutherland, M. 1991. Hierarchical Partitioning. American Statistician 45, 90-96.

Chiron, F., Shirley, S. \& Kark, S. 2009. Human-related processes drive the richness of exotic birds in Europe. Proceedings of the Royal Society BBiological Sciences 276, 47-53.

Cramp, S. \& Simmons, K.E.L. 1980. The Birds of the Western Paleartic. Vol II. Oxford University Press, Oxford.

De Frutos, A., Olea, P.P. \& Vera, R. 2007. Analyzing and modelling spatial distribution of summering lesser kestrel: The role of spatial autocorrelation. Ecological Modelling 200, 33-44. 
Gibson, L.A., Wilson, B.A. \& Aberton, J.G. 2004. Landscape characteristics associated with species richness and occurrence of small native mammals inhabiting a coastal heathland: a spatial modelling approach. Biological Conservation 120, 75-89.

Graham, M.H. 2003. Confronting multicollinearity in ecological multiple regression. Ecology 84, 2809-2815.

Heikkinen, R.K., Luoto, M., Kuussaari, M. \& Pöyry, J. 2005. New insights into butterfly-environment relationships using partitioning methods. Proceedings of the Royal Society B-Biological Sciences 272, 2203-2210.

Heikkinen, R.K., Luoto, M., Virkkala, R. \& Rainio, K. 2004. Effects of habitat cover, landscape structure and spatial variables on the abundance of birds in an agricultural-forest mosaic. Journal of Applied Ecology 41, 824-835.

Leprieur, F., Beauchard, O., Blanchet, S., Oberdorff, T. \& Brosse, S. 2008. Fish invasions in the world's river systems: When natural processes are blurred by human activities. Plos Biology 6, 404-410.

Luoto, M., Heikkinen, R.K., Poyry, J. \& Saarinen, K. 2006. Determinants of the biogeographical distribution of butterflies in boreal regions. Journal of Biogeography 33, 1764-1778.

Mac Nally, R. 2000. Regression and model-building in conservation biology, biogeography and ecology: The distinction between and reconciliation of 'predictive' and 'explanatory' models. Biodiversity and Conservation 9, 655671.

Mac Nally, R. 2002. Multiple regression and inference in ecology and conservation biology: further comments on identifying important predictor variables. Biodiversity and Conservation 11, 1397-1401.

Mac Nally, R. \& Walsh, C.J. 2004. Hierarchical partitioning public-domain software. Biodiversity and Conservation 13, 659-660.

Marini, L., Prosser, F., Klimek, S. \& Marrs, R.H. 2008. Water-energy, land-cover and heterogeneity drivers of the distribution of plant species richness in a mountain region of the European Alps. Journal of Biogeography 35, 18261839.

McAlpine, C.A., Rhodes, J.R., Callaghan, J.G., Bowen, M.E., Lunney, D., Mitchell, D.L., Pullar, D.V. \& Possingham, H.P. 2006. The importance of forest area and configuration relative to local habitat factors for conserving forest mammals: A case study of koalas in Queensland, Australia. Biological Conservation 132, 153-165.

Millington, J.D.A., Perry, G.L.W. \& Romero-Calcerrada, R. 2007. Regression techniques for examining land use/cover change: A case study of a mediterranean landscape. Ecosystems 10, 562-578.

Müller, J., Pöllath, J., Moshammer, R. \& Schröder, B. 2009. Predicting the occurrence of Middle Spotted Woodpecker Dendrocopos medius on a regional scale, using forest inventory data. Forest Ecology and Management 257, 502-509.

$R$ 2006. R: A language and environment for statistical computing. R Foundation 
for Statistical Computing. R Development Core Team, Vienna, Austria. Downloaded on http://www.rproject.org.

Siegfried, W.R. \& Skead, D.M. 1971. Status of the Lesser Kestrel in South Africa. Ostrich 42, 1-4.

Walsh, C. \& Mac Nally, R. 2004. "The hier.part Package" version 1.0. Hierarchical Partitioning. Documentation for $\mathrm{R}$ : A language and environment for statistical computing. R Foundation for statistical Computing, http://www.rproject.org.

Walsh, C. \& Mac Nally, R. 2005. "The hier.part Package" version 1.0-1. Hierarchical Partitioning. Documentation for $R$ : A language and environment for statistical computing. $R$ Foundation for statistical Computing, Vienna, Austria. http://www.rproject.org.

Walsh, C. \& Mac Nally, R. 2007. "The hier.part Package" version 1.0-2. Hierarchical Partitioning. Documentation for R: A language and environment for statistical computing. $R$ Foundation for statistical Computing, Vienna, Austria. http://www.rproject.org.

Walsh, C. \& Mac Nally, R. 2008. "The hier.part Package" version 1.0-3. Hierarchical Partitioning. Documentation for $\mathrm{R}$ : $\mathrm{A}$ language and environment for statistical computing. $R$ Foundation for statistical Computing, Vienna, Austria. http://www.rproject.org.

Walsh, C.J., Papas, P.J., Crowther, D. \& Yoo, J. 2004. Stormwater drainage pipes as a threat to a stream-dwelling amphipod of conservation significance, Austrogammarus australis, in southeastern Australia. Biodiversity and Conservation $13,781-793$. 


\section{Agradecimientos}


Pues sí!!! Por fin la tesis ya está terminada tras un laaargo tiempo marcado por las distintas etapas por las que he pasado. Desarrollar, y finalizar, esta tesis doctoral ha sido gracias a la paciencia de mi codirector Pedro P. Olea. La calidad científica de esta tesis ha sido posible gracias a su clarividencia de cómo plasmar nuestra investigación en los artículos científicos. Hartito le he tenido por corregirme las numerosas versiones de un mismo manuscrito. También ha sido fundamental su capacidad de generar ideas para investigar y de tratar los datos con novedosos métodos estadísticos. Ni me imaginé que acabaría haciendo una tesis doctoral cuando me lo presentó Rafa para pedir la ayuda de introducción a la investigación de la Fundación Monteleón-Caja España.

Francisco J. Purroy depositó su confianza en mí como codirector de la tesis doctoral. Con él he podido realizar la tesis con una beca predoctoral en el área de zoología de la Universidad de León y acabé siendo su ave fénix. Sus innumerables anécdotas enriquecieron mis saberes sobre la agricultura, la PAC, las ayudas agroambientales, las aves, regadío, gastronomía, gentes y curiosidades del área de estudio de la tesis.

También me enriquecieron los seminarios de nuestro grupo de 'biobecarios' del departamento (Nico, Ángela, Víctor C., Esther, David, Sergio, Laura, Patricia, Carlos, Víctor L., Manu, Jac, Félix, Octavio, Jacinto y Pedro). Juntos aprendimos las diferentes destrezas necesarias para llevar a cabo la tesis doctoral (para quien no lo sepa: gestión y búsqueda de bibliografía, estadística, papeleos administrativos, lectura crítica de artículos, escribir artículos, informes, permisos, presentaciones orales, GIS, cafés....). Nico fue una pieza fundamental con todo lo relacionado con el departamento (derechos y deberes) y tuvo mucho aguante por darme consejos que solucionasen mis interminables trabas administrativas y técnicas. Manu, gracias por la silueta!

Muchos fueron los que me acompañaron y me ayudaron en el campo para tomar datos. Agradezco por ello la colaboración de Hugo, Rubén, Olga, Kike, Cristina, María del Carmen, Soledad, Irene, Rodolfo, Rafa, Gema, Ricardo, Pancho y Patricia. Álvaro, Jesús y Rafa me facilitaron sus telescopios.

Ha sido fundamental la insistencia de Patricia en que acabara la tesis. Ella siempre me ha echado una mano cada vez que lo necesitaba y se ha convertido en mi amiga y compañera de trabajo indispensable para estos años venideros. Gracias por tu apoyo rkt!

Por último quería agradecer a todos los que me apoyaron y que me animaron con la famosa frase de... ¿pero cuándo la acabas?, sobre todo a mi familia (especialmente a mis padres), Marijose y Rubén y sus familiares que me resolvieron mis dudas agrarias, a mi peña los 
Kalandrakas, al grupo de Crápulas-Aula Dei de Zaragoza (especialmente a Montse y Jorge), a la Fundación para la Conservación del

Quebrantahuesos (FCQ) y al grupo de Los Correcaminos (especialmente a María por su constante apoyo).

Gracias a todos por ayudarme!!! 
